A2ti:

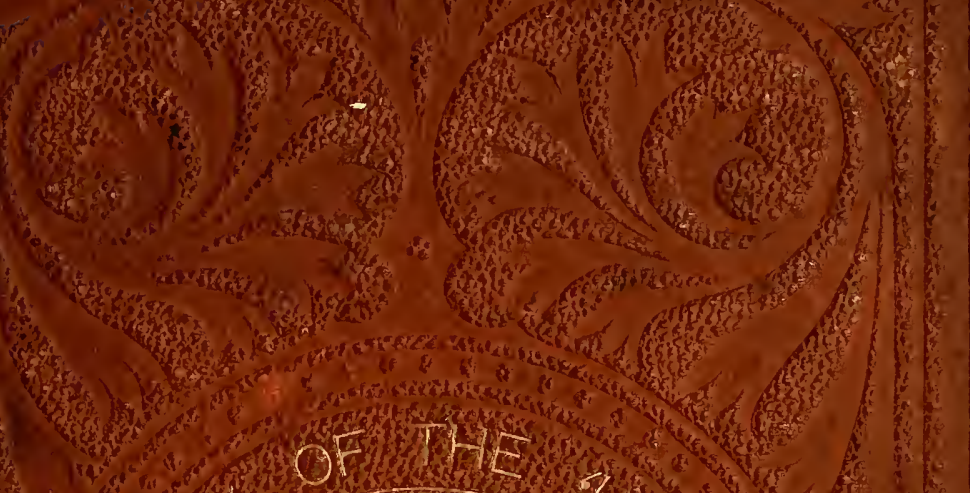

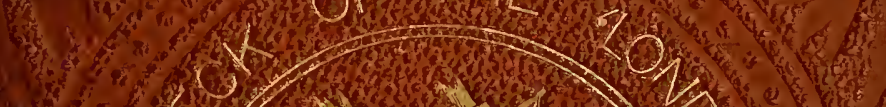

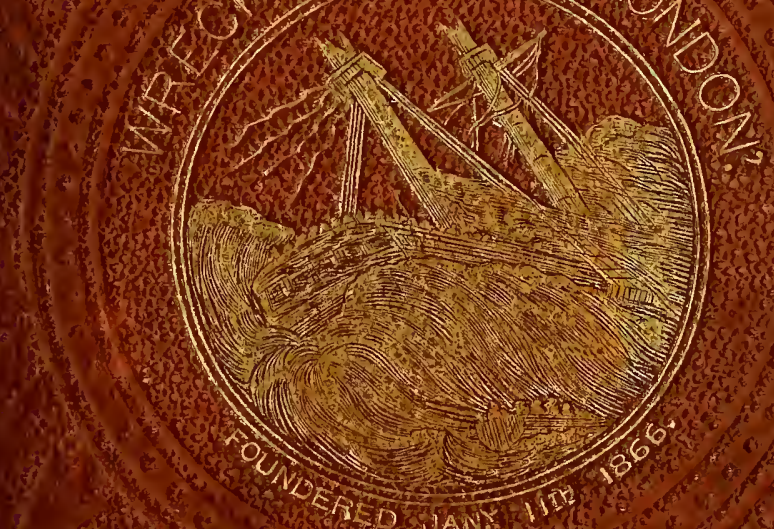

3) 3 (4)

s.

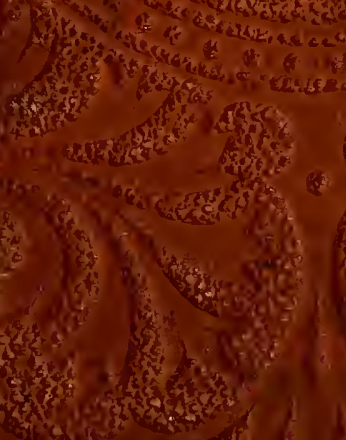




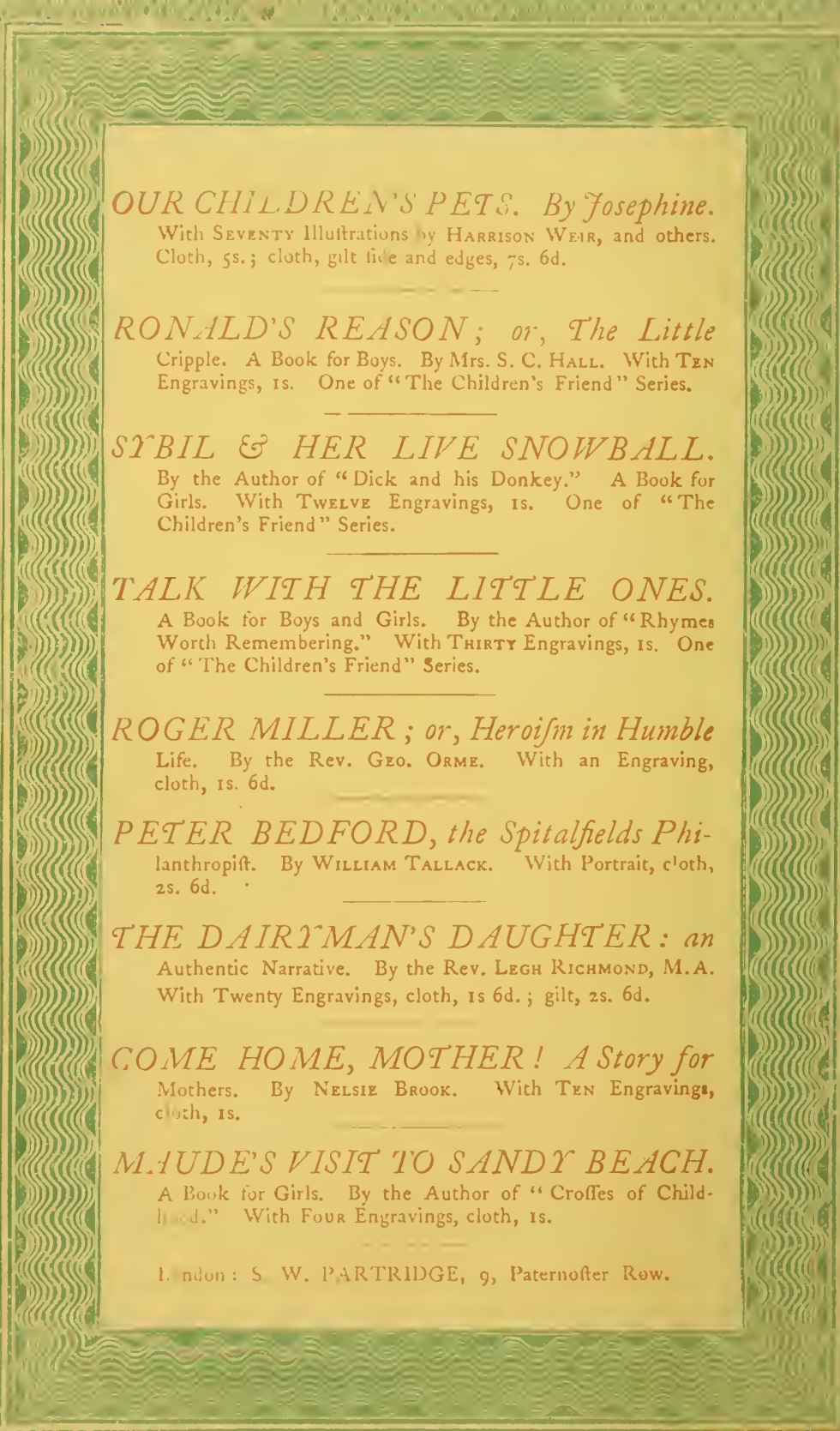


PROCRASTINATING M.ARY: A Story for Young Girls. By the Author of "Croffes of Childhood." With Two Engravings, $6 \mathrm{~d}$.

ROSA; or, The Troo Caftles. By Mifs BRADBURN. A Tale for Girls. With EIGHT Engravings, cloth, Is.

[New Edition.

PASSAGES IN THE HISTORY OF A SHILliNG. By Mrs. C. L. Balfour With Five Engravings, cloth, Is.

New Edition.

OUR DUMB COMPANIONS; or, Stories about Dogs, Horfes, Cats, and Donkeys. By Rev. T. JACKson, M.A. With SEventY-FIVE Engravings, cloth, $5 \mathrm{~s}$. ; gilt, 7 s. $6 \mathrm{~d}$.

[Eleventh Thoufand.

THE LITTLE WOODMAN Eं HIS DOG CASAR. By Mrs. Sherwoov. Parlour Iffue on toned paper, cloth, Is. 6d.; gilt, 2s. 6d. [New Edition.

WASTE NOT, WANT NOT. A Book for Servants. By Mrs. Sherwood. Printed on toned paper, cloth, Is. 6 d. ; gilt, 2s. 6 d.

[New Edition.

THE MOTHER'S PICTURE ALPHABET. Printed on Toned Paper, With Twenry-sIx Engravings, boards, 5 s.; cloth, red edges, 7s. 6d. ; gilt edges 1os. $6 \mathrm{~d}$.

[Seventh Thoufand

A MOTHER'S LESSONS ON THE LORD'S PRAYER. By Mrs. BALFour. With EigRT Engravings, illuftrated cover, 2s. 6d, ; cloth, 3s. 6d. ; clotb extra, 5 s.

London: S. W. PARTRIDGE, 9, Paternofter Row

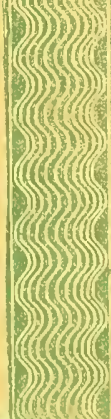


15 



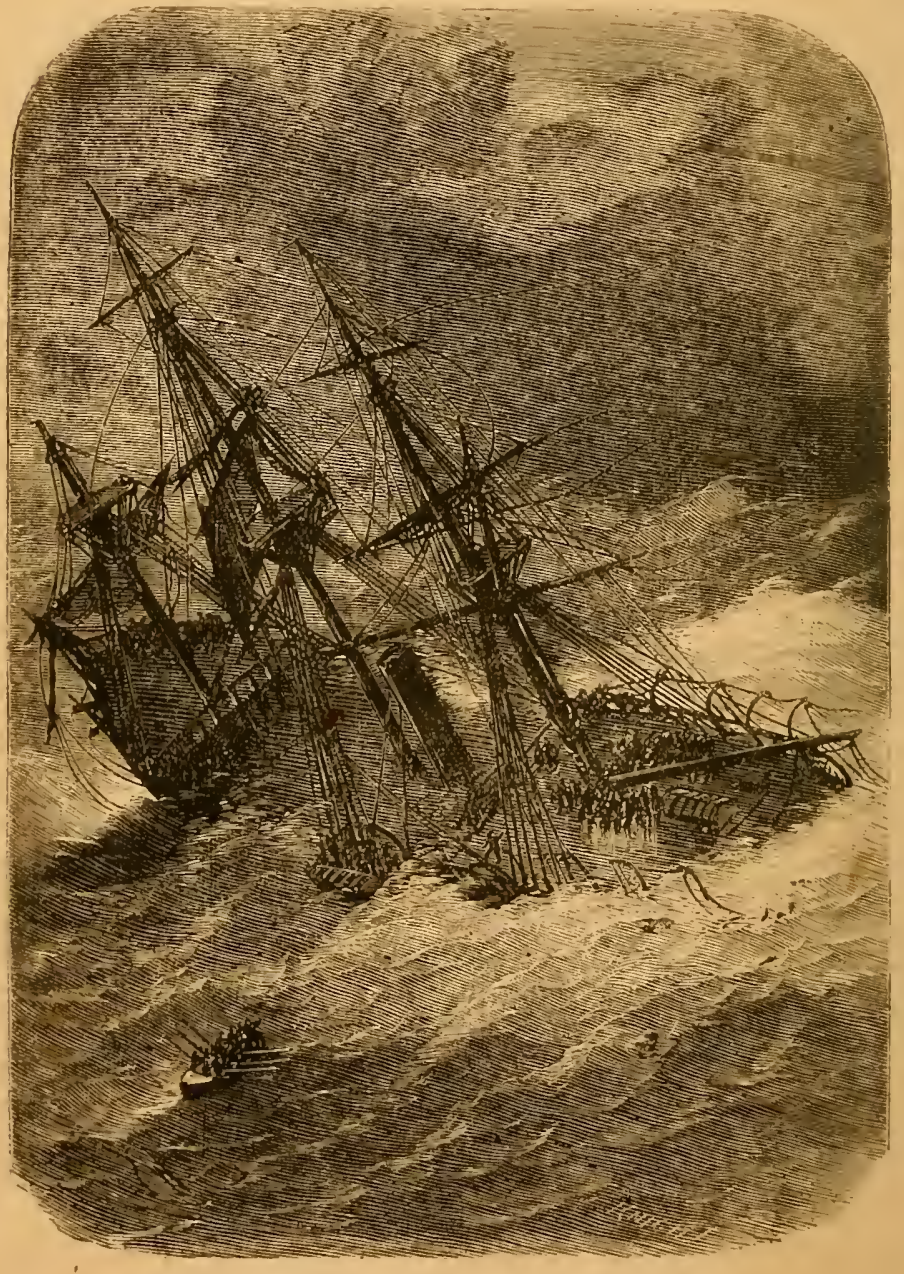

THE LAST OF THE "LONDON." 


\section{WRECK}

of

\section{THE}

\section{"LONDON."}

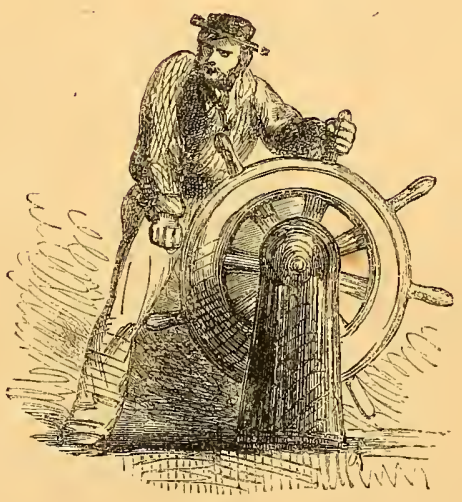

Second Edition-Revised.

\section{LONDON:}

S. W. PARTRIDGE, 9, PATERNOSTER ROW. 


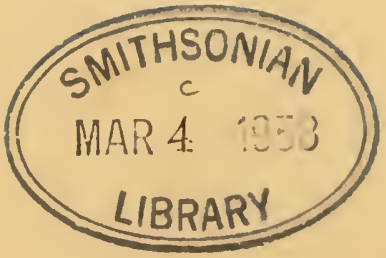

The Publisher will be glad to receive any additional information from those who had friends or relatives on board. 
910.4

. W 94

Mit?

\section{ONTENTS.}

CHAPTER I.

INTRODUCTORY • . . . . . . . . P. 1

CHAPTER II.

The Iron Behuty . . . . . . . . 5

CHAPTER III.

Captan Martin . . . . . . . . . 12

CHAPTER IV.

Pev. Daniel Jayes Draper

CHAPTER V.

The List of Passengers . . . . . . . 36

CHAPTER VI.

Three Days and Nights of Danger on the Deep • . 48

CHAPTER VII.

LAst Struggles .

CHAPTER VIII.

The Anchor within the Veil . . . . . . 63 
CHAPTER IX.

LAsT Words

•

CHAPTER X.

The Ligit' behind the Cloud .
CHAPTER XI.

The Esc.spe

CHAPTER XII.

THINGS REMEMBERED IN THE STORII

$$
\text { APPENDIX. . . . . . } 101
$$




\section{WRECK OF THE "LONDON."}

\section{CHAPTER I.}

INTRODUCTORY.

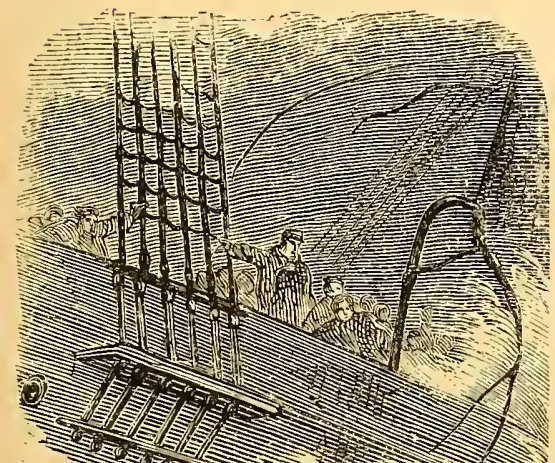

'THE opening of the year' 1866 will long be memorable for that dismal series of disasters at sea, which it ushered in with a frequency and fatality that were truly appalling. The New Year was scarcely fourteen days old when, from every

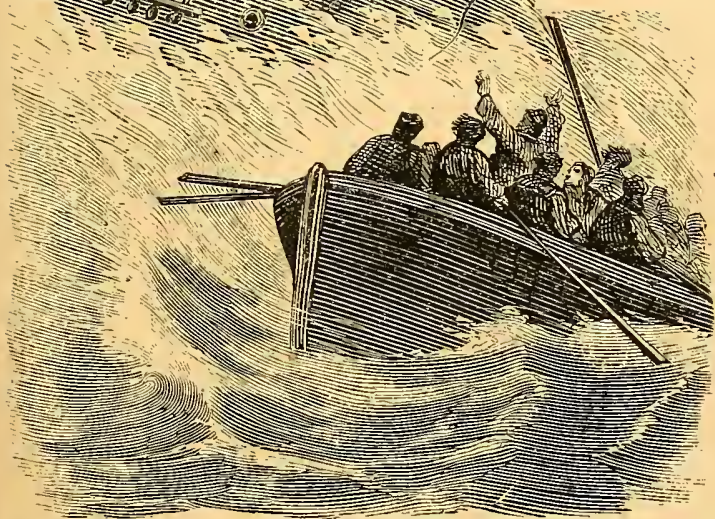
part of the coast, from north to south, from east to west, the telegraph flashed the melancholy tidings of ruin and ha. voc among the shipping.

We heard of ships being dismantled by the storm, and obliged to put back to port; of others being beaten to pieces, 
while their crews, escaping by the lifeboats, performed sucl acts of heroism that the seaman's name was corered with fresh renown. Since the year 1859 never had such tempests raged, and such deeds of gallantry been performed.

But disaster seemed indeed to crown disastel, when it way rumoured that the London-one of Messrs. Wigram's finest ressels, laden with a raluable cargo, and haring, it was first said, more than 300 souls on board-had foundered in the Bay of Biscay, and that not a soul had escaped. At first, many positively refused to credit the intelligence that the noble ressel, which had only a few days left our shores, had succumbed to the fury of the gale, and gone down a wreck. It seemed impossible. Relatives and friends were loth to receive the terrible truth that they had taken a last farewell of many, the grasp of whose hand they still felt warm within their own, and whose last words of love and friendship were still ringing in their ears. All were slow to admit that there was no hope, and there was a gencral clinging to the expectation that there had been some mistake. The London might, perhaps, have been injured by the tempest, and compelled to put back to port; but that she could have foundered, or even if this calamity had occurred, that her crew and passengers had been unable to effect their escape-this indeed seemed almost beyond belief !

Too soon, however, the newspapers brought the sad and affecting story before the eyes of all, and never did story of shipwreck, however thrilling, excite a grief more sincere and wide-spread. It needed no artistic craft to make the story tell, and to take it straight home to the learts of unmumbered thousands. "This awful wreck," said Mr. O'Dowd in conmencing the inquiry directed by the Board of Trade, "has been the theme of many a pert, and the topic of many a con- 
versation since its occurrence has been made known. Though the sympathies of our hearts ought to recognise no grades of social position, nor any distinction of education and. intellect, we yet must feel the pang embittered by the loss of some of the passengers, with whose names, accomplishments, and virtues the public are now painfully familiar."

As, day by day, the harrowing details became more accurate and complete, the regret became more and more poignant, and almost assumed a national character. Men soon thought little of the ship, magnificent though she was, or of the cargo, valuable as that was; both ship and cargo became insignificant in the presence of the rast sacrifice of human life by which the wreck of the London had been accompanied. And then came tales of heroism and self-denial, of a lofty courage and sweet resignation on the part of her passengers, officers, and crew, that made it harder still to realize that the men and women who had been capable of such noble behaviour had been buried beneath the foaming waves, and that the world now was all the poorer and more desolate, for their absence from it. Both the pulpit and the press gave touching and eloquent expression to the grief which prevailed on every side; and while the mourning relatives of our own land received every mark of sympathy and consideration, those belonging to the colonies, and on whom the news will burst like a terrible thunderbolt, were not forgotten, either in the earnest prayers that were offered on behalf of the bereaved ones, or in the words of genuine kindness and commiseration which the knowledge of their heavy loss elicited.

It has been thought that there is much belonging to the Wreck of the London which entitles it to a more convenient jlace of record than the newspaper, and that many, both in England and Australia, will be glad to possess a simple, con- 
nected narrative of the ship's doings, and especially of her passengers' bchaviour from the day they left our shores until the day of their foundering in the Bay of Biscay.

There can be no question that the heroism and piety displayed on the occasion, demand a most distinguished place in the annals of the brave and good. Unhappily, shipwrecks of the most disastrous character are of only too frequent occurrence; but it is seldom that a Message from the Sea has borne the character of that mysterious and sublime one which the sinking London wrote ere she went down. Many, too, will perhaps be glad to possess portraits of those whose names will now be historical for their behaviour amid the distressing circumstances in which they were placed.

It is also in the sincele hope of administering some balm of consolation, however slight, to the hearts of thousands mourning in our own country and elsewhere, that we would now, avoiding, as far as possible, technical terms and details, invite the rearler's attention to the narrative of the Wreck of the Iondon, first of all, however, looking at the ship herself, her Captain, and her list of passengers.

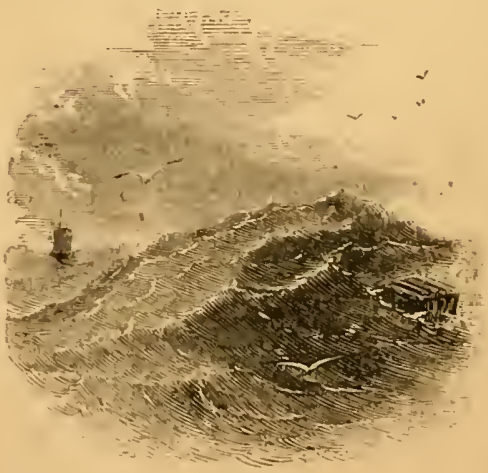




\section{CHAFTER II.}

\section{THE IRON BEAUTY.}

THE London was the property of Messrs. Money Wigram \& Co., the eminent shipbrokers at Blackwall, to the extent of fifty-six shares, Messrs. Franklin and Charles Morgan being owners of two shares each, and Captain Martin, her Master, of four. She was a screw steam-ship, and was built at Blackwall in 1864 ; she was therefore a new vessel. She liad two decks, three masts, was ship-rigged, and clincher-built. She was 1752 tons register, and her engines, by Messrs. Humphreys and Tennant of Deptford, were constructed on the most improved modern principles: they were 200 horse power. Her length, from the fore part of the stem, under the bowsprit, to the aft side of the head of the stern post, was about $276 \mathrm{ft}$., and her main breadth to outside of plank was about $35 \mathrm{ft}$.; her depth in hold, from tonnage deck to ceiling at midships, was 24 feet.

The materials used in the construction of the vessel were all of the best quality, and the best workmanship was used. The materials were an angle iron frame, iron beams, stringer plates and kelsons. Slie was double rivetted from keel to gunwale, ard all her fastenings were sound and good. Her masts were iron, with the exception of her topmasts, which were of wood. Those who superintended the progress of her building from the laying of her keel until the day of launching, have spoken in terms of the most unqualified approbation of her entire construction; and those who officially examined lier before she put to sea, reported her in the best trim, and having all the equipments necessary for the voyage. Sails, 
compasses, boats, anchors, rockets, signal guns, life buoys, in short, all that she was required to carry to be officially pronounced seaworthy, the London did carry; and, previous to her last voyage, after undergoing a series of examinations, she was said to be as fine a vessel as ever left the Port of London, and she presented to the eyes of her admirers a perfect picture of combined elegance and strength. She was built according to Lloyd's rules and regulations, and was indeed of greater strength than Lloyd's rules required.

On account of the melancholy disaster commected with them, the reader's attention must briefly be directed to the engine-room of the vessel, and the hatchway over it. The engine-room was $36 \mathrm{ft}$. in length, and on either side of it, fore and aft, were bulkheads, to one of which there was a communication from the engine-room. Over the engine-room went the hatchway, the dimensions of which were about $12 \mathrm{ft}$. by $9 \mathrm{ft}$. The hatchway was a saddle skylight in a wooden frame, having plate glass half an inch thick, and covered with gratings of galvanized iron. According to the judgment of those who surveyed the ship, the engine hatch was deemed of sufficient strength to meet any weather.

Such, then, was the vessel, which was no sooner advertised for her third voyage, than all her berths were taken, and a valuable cargo got on board. The accommodation for forecabin passengers was on the main deck before the main hatchway. In this part of the ship there was space for $130 \mathrm{in}$ hammocks and 128 in berths, thus providing accommodation for 258 persons. The accommodation for after-cabin passengers amounted to 132 berths and space for 10 hammocks; thus taking 142 passengers. Altogether the ship would carry 400 persons. From the shipping bills of the London we find that her cargo consisted of about 347 tons of dead weight, viz. 
iron plates and bar's, sheet iron, lead and shot, stone, blocks, iron nails, and screws, \&c. ; there were also 14 tons of hardware and agricultural implements, all of which would not be probably considered dead weight. The remaining portion of the ship's cargo, amounting to about 1000 tons, consisted of light goods, packages of haberdashery, blankets, woollens, china, glass, ware, drugs-in short, just such a cargo as was generally exported to Australia: this was storred over the dead weight, and in the after part of the ship. The cargo of bar and sheet iron was stowed from the after part of the main hatchwar to the after part of the fore hatchway. The value of the cargo was estimated at $124,785 l .17 s .4 d$.

The weight of the cargo was, of course, increased by the coals which the London carried. The quantity of coals supplied to the ressel was as follows:-remaining on board from the previous royage, 45 tons; shipped in London, 460 tons; making in all 505 tons. Of this there was expended on the voyage to $\mathrm{Plymouth} 47$ tons, leaving 458 tons. There was shipped at Plymouth 50 tons; so that the weight of engine coals in the ship when she left Plymouth was 508 tons. Sereral tons, however, were on deck, stowed in sacks round the steam-chest and engine-room hatch, and, during the storm that broke over the ressel, the coals were thrown out of their sacks, and at every lurch of the ship they were either washed overboard, or sent rolling in kuubs near the scuppers.

The master and officers of the ship were as follows:John Bohun Martin, Naster; Robert Harris, first mate; Arthur William Ticeliurst, second mate; Arthur C. Angell, third mate; John Jones, first engineer; John Greenhill, second engineer. The Master, cfficers, and crew were in number 83, and there were 15 fureigners among the seamen. The foreigners were all rated as able seamen, and amongst them 
were 3 Germans, 5 Swedes, 2 Russians, 2 Danes, 1 Hollander, and 1 Bavarian. It does not appear that any of the forcigner's had sailed in the I.ondon before, but eleven out of the number. had previously sailed on board of British ships.

The number of passengers that went on board in London was 125 , and these were increased to 180 by the embarkation of 55 at Plymouth. That the London stvod very high in the estimation of all sea-goers, and that her seaworthiness was above the faintest suspicion, is evident from the number of those whu tried to secure a passage ont in her, but without success, and from the reports and declarations which all those who were officially responsible for her good trim made respecting her. After a certain time there was not a berth in her to be obtained on any terms, though many were disappointed at not being allowed to obtain them : there was not a word of dissatisfaction, however slight, expressed by any ofticial after the strictest examination liad been made. Captain M'Lean, the Emigration Officer, who acts under the authority of the Emigration Commissioners, had, after careful survey and inspection, certified the London to be in safe trim, and in all respects fit for her intended voyge to Melbourne. His words were, "I consider her perfect in every way."

It would have been umnecessary to have appeared even to insist upon the good trim and seaworthiness of the London, had rot the suspicion grained ground that much nore might have been done for the passenger's' safety than actually was done. Some have thought that more boats onght to have been on board; but it shonld be borne in mind that she carried one more than was actually required by law, and that no ship carries a sufficient number of boats to contain all on board, unless the number of passengers happens to be very slight.

With refesence to the length, breadth, and depth of the ship, 
a suggestion has been thrown out as to her narrowness of beam for a vessel of such length; but this alleged disproportion was not peculiar to the Londm: it exists in a much grreater degree in some of the finest ships afloat. The length, for example, of Her Majesty's transport ship Himalaya is $340 \mathrm{ft}$., while her breadth is only $44 \mathrm{ft} .7 \mathrm{in}$. The same might be noticed in the case of other steam-ships.

We have no doubt that eventually, out of the terrible calamity that all must truly deplore, greater safety will accrue to the thousands who sail the seas, through greater care being taken of every means that concerns such safety, and that inmediately some plan will be devised for securing the engineroom of steam-ships against inundation.

Meanwhile the matter will not be mended by any unfair criticism of the ship's sea-going qualities. It will only increase unavailing regrets, to array what might have been against what actually is. It is a fact, patent to all, that the London enjoyed a first-rate reputation as a fast ship, as a most comfortable one, and as having in her commander, Captain Joln Bohun Martin, a gentleman of the highest repute, both for his seamanship and many other admirable qualities.

All being in readiness, the London left the East-India Docks on the 29 th of December 1865, laden as we have described, and bound for Melbourne. Many were those who caught a view of her from various points as she steamed majestically down the river, and fervently wished her a prosperous voyage as they remembered that she contained on board something far more precious than all her cargo, rich though it was.

At Gravesend she erinbarked several passengers, and lunch was prepared on board, that those who were about to separate, they knew not for how long, might enjoy as much of each other's society as possible. It was a pleasant party, 
notwithstanding the tears that started involuntarily from many eyes as the hour of separation drew near. One affecting inciclent deserves to be recorded. A gentleman was obliged to send his little boy out, and remain behind himself. The child was to have gone by a former ship, but he had prevaled upon his father to allow him to wait for him; and now, after all, that dear father could not go until the next ship, and the little one was going out under the care of a friend. The father of the child was present, and watched the vessel until she seemed to die away in the glory of the setting sun.

Innumerable, doubtless, now are the kind words and looks which are recalled by mourning friends as so many fond souvenirs of that last parting at Gravesend or at Plymouth. The sun was going down, and tinging with lustre the Kentish hills, wintry though the weather was, when the London left Gravesend behind, and went on her way to Plymouth. This very night, however, she encountered weather that compeller her to bring up at the Nore, where she anchored and remained during the whole of Sunday.

On Monday morning, the 1st of January, at daybreak, the anchor was weighed, and the ship steamod down the channel, still against a head wind, but making fair way. While passing outside the Isle of Wight the wind increased to half a gale, and Captain Martin deemed it prudent to put back and lay-to for the night in St. Helen's Road. On Tuesday morning, the 2nd, the London proceeded through the Needles into the open channel, the wind being still ahead, but light. On the IVednesday the weather became so boisterous, and the indications of the barometer so threatening, that, at about 2 o'clock r.M., the Trinity House pilot, under whose care she was, decided on taking her to Spithead for shelter. She anchored on the Mutluerbank at 4 P.Mr, and 
lay there until daylight of the 4 th, when she steamed out through the Needles passage, the wind being then southwesterly.

She arrived off Plymouth at daylight of the 5th. A sad accident occurred here. A pilot cutter put off a small boat, having on board the pilot and his assistant, to bring the London inside the breakwater. When the boat was no more than a hundred yards from the London a sea capsized her, and both the pilot and his assistant were thrown into the water. Captain Martin instantly ordered one of his life-boats to be lowered, and with great difficulty the assistant pilot was rescued, but the pilot was drowned. About two hours after daylight of the 5th the London was anchored inside the breakwater, and prepared at once to embark her passengers. Some of those passengers must now engage our attention for a little while.

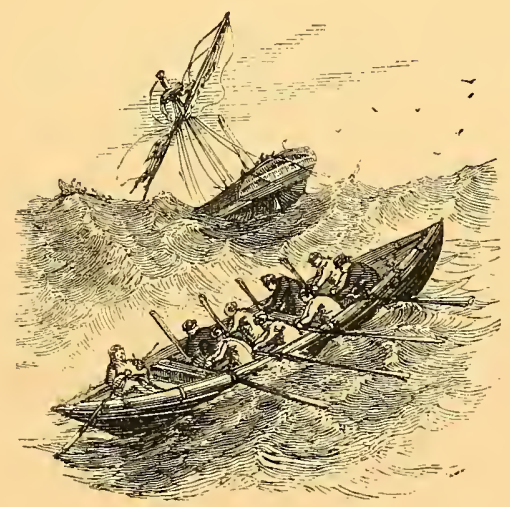




\section{CHAPTER III:}

CAPTAIN MARTIN.

It will be long before Britons will hear the name of Jolin Bolun Martin without tears, as they think of his noble heroism amid eircumstances sufficiently appalling to rob the bravest of his self-possession; of his disregard for his own personal safety while duty commanded him to remain at a post of imminent danger; of his resolute perseverance in doing all that the most skilful seaman could, to ride ont the furious gale. He was not new to the sea, for from his boyhood he had been accustomed to cope with its storms and dangers, and had not risen to the post of Master without passing through years of the most careful training and discipline. He was born at Brompton, April 27th, 1819. When yet young, having a love for the sea, he was entered as midshipman in the East India ship True Briton, and made several voyages to Madras, Bombay, and Calcutta. He remained in this ship four years, and during this time he diligently studied navigation, particularly in its scientific branches. In 1840, he was appointed third officer of the Southampton, a vessel trading to the East Inclies, and having in those days some celebrity as a fast-sailing ship. He passed timough twelve additional years of service before he was entrusted with the command of a vessel, but all who knew him spoke very highly of his diligence and general character. He enjoyed the esteem and friendship of the Captains under whom he served: among them were the rell-known names of Beach, and Wimble, and Nash. 


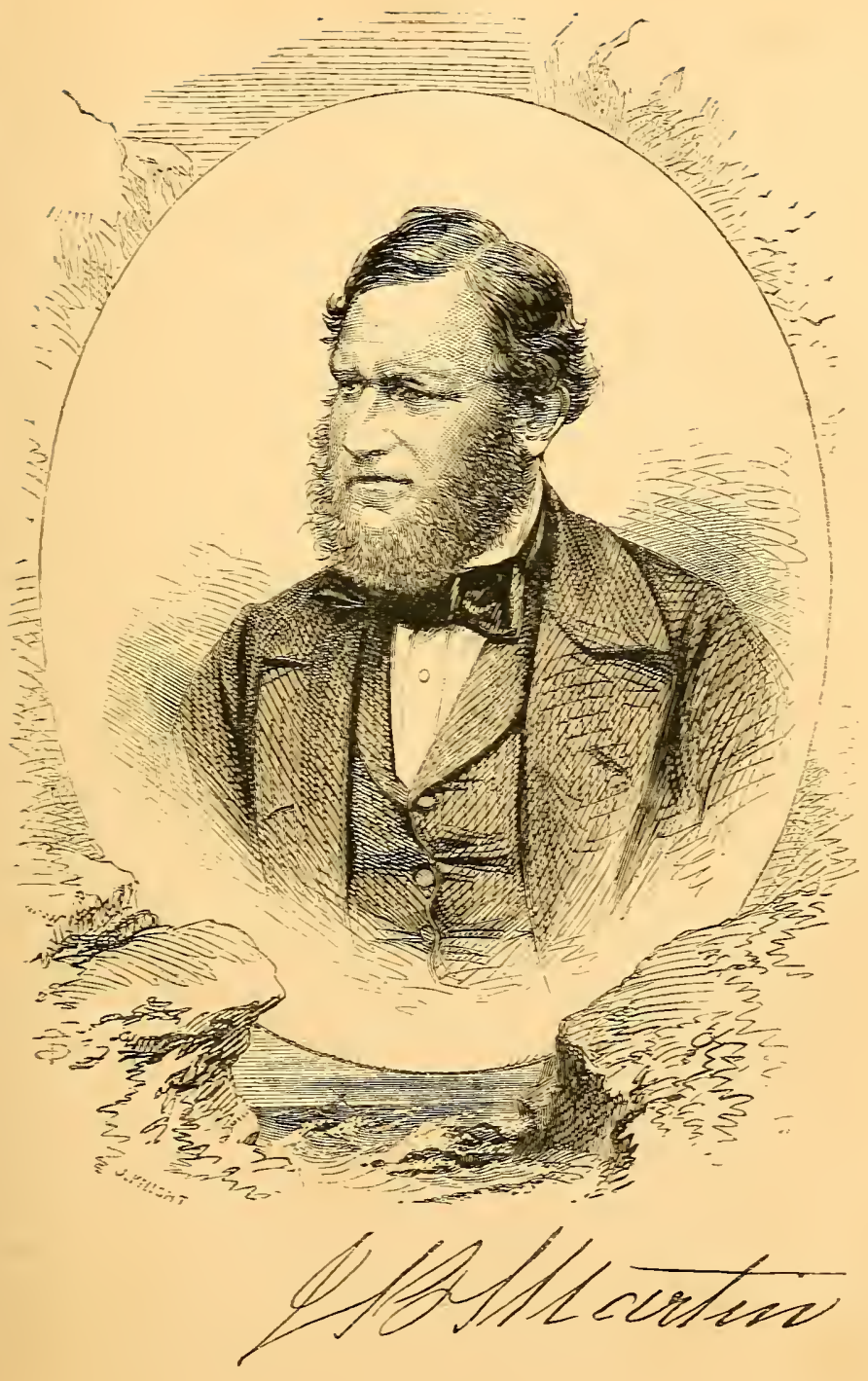



In the year 1852 he was appointed to the command of the Essex, and continued her Master four years; at the end of which period he took the command of the Suffolk. There is no doubt that he owerl this appointment entirely to his own merits as a navigator, and to the confidence which his general character inspired. The post which the Captain of the Suffolk was expected creditably to fill, was in every way an honourable, but, at the same time, a most responsible one. The ship was one of Messrs. Wigram's best and fastest-sailing clippers, and was expressly designed for the Australian trade. In 1856 the gold-digging mania in Australia was attracting great numbers of people from our shores, and there was a sharp competition amongst ship-owners, both for passengers and cargo. Fast vessels were much in demand, for, to the travellers athirst for gold, a single day was deemed of the greatest importance; and safe ships were of course sought after, because of the precious cargo entrusted to their keeping.

Accordingly, during that period a number of fine vessels were built and launched, and their owners were accustomed to start them at the same time and for the same destination. The Suffolk, however, could successfully compare with any vessel of her class, as she had been expressly built for the Australian tracke, and, regardless of cost, had been fitted by her wealthy owners with all the equipments necessary to render her one of the fastest and, at the same time, safest ships afloat.

From a host of able and experienced navigators, who would have counted it an honour to have assumed the command, Messrs. Wigram selected John Bohun Martin to be Captain of the Suffolk, and never did owners make a better choice. Many are still living who crossed the seas with him during those days of well-nigh angry com- 
petition, and who will recall with pleasure his practised skill, his genial, open disposition, his gentlemanly bearing, and his studious care for the comfort of his passengers in all the little details which have so much to do with the making or marring of the pleasure of a long royage. He was one of the kindliest and most simple-hearted of men, pleased with very simple things, delighting in riddles in which a very child - would hare seen no mystery, and with all a sailor's superstition about him; fond of cats, and a great partiality for absolutely doing nothing at all when he was not on board. With his attached relatives in Highbury Park he would always spend his time when ashore, and go about with them here and there; but he was perhaps never happier than when he could throw himself back in the large easy chair, and read the advertisements of the Times and the advertisement especially of his own ship. Not tall, and not short, and every inch the grentleman; with a fresh-coloured face, light hair and blue eyes, and ambling motion, as if in any place he wanted sea-room and must have it; with a fine cheery voice, and a langh of sterling quality; with a woman's heart of tenderness within the strength that seemed equal to any danger-as such, John Bohun Martin will long be remembered.

One who knew him well, and who could not speak of his loss without deep emotion, told the writer of many little acts of attention, which, although too trivial to appear in print, are not without importance when measured by the comfort they imparted, and by the roirt which their absence would have created. His heart was truly in his profession, and he had all the gemuine sailor's enthusiasm, and, we might almost say, affection, for his ship, of whose equipments, beauty, and good qualities he spoke with glowing pride. As he was never married, some used langhingly to say that the Captain had 
no bride but his ship; and certainly he had reason to be proud of the Suffolk during the eight years she was under his command.

Her first trip to Australia was performed with unusual rapidity. It is true that, on this passage, she encountered very heavy weather: a violent hurricane carried away her topmasts, and for a short time crippled her; but the damage was quickly repaired at sea, and notwithstanding this mishap, the Suffolk arrived in Australia in an unusually short time, and could bear to be favourably compared with some of the finest vessels afloat, which had started at the same time. Captain Martin had displayed such skill, and had shewn such energy in circumstances that were fraught with much danger both to passengers and cargo, that, upon his return to England, the mercantile portion of the city of London presented him with a handsome testimonial as a mark of their esteem. A sum of more than $£ 500$ was presented to him.

An interesting story stands connected with the first voyage of the Suffolk. While shẹ was in a dismantled condition, and her crew were repairing damages, an American vessel, also bound from London for Melbourne, spoke the Suffolk, and offered assistance. Captain Martin courteously declined, whereupon the American Captain said he would report the Suffolk on his arrival at Melbourne. Captain Martin replied, that he had better take care the Suffollk did not report him. The vessel proved that Captain Martin's confidence in his ship, and in his own seamanship, was not ill-founded. The American Captain reached Melbourne after what he considered a rapid passage, and the day after his arrival called on the agents of the Suffolk and reported having fell in with her. They thanked him, and 
asked would he like to see Captain Martin, who was in the next room. The American Captain was much surprised to find that the Suffilk had arrived five days before and reported him.

The Suffill now commenced a career of success which enabled her, under the direction of her able commander, to take rank before all other ships in the same trade. She made, during eight years he commanded her, ten voyagres to Australia and back; nor did she meet with any mishap or casualty of any kind, save that to which we have referred on her first trip. During these years Captain Martin not only enjoyed the high esteem and friendship of her owners, but also of men high in position both in England and Anstralia. It will be hard to say, perhajs, in which comtry his loss will be the more deeply felt; fur, both at home and abroad, he numbered a multitude of attached and admiring friends. Ile was a man pre-eminently fitted, it seems, to infuse what was loving and kindly in others: not only among passengers, but among those who were under his command, he is described as being one of the most trueminded and unselfish of men. Mr. Greenhill, the second engineer of the Iondun, and one of the survivors, a man who, without a tear, had faced all the horrors of the wreck, and all the dangers of the raging sea for twenty-four hours, in an open boat, fairly hroke down, and sobbed like a child, as the thought of his last interview with the gallant Captain presented itself to his mind.

Many of the passengers with him on former voyages can recall, not only his gentlemanly tastes, but the extreme simplicity of his habits. While he kept one of the best and most hospitable of tables fur those on board his ship, his own wants were of the most moderate description. On last 
Christmas-day his moderation at the table of his relatives called even for remark: he touched neither wine nor spirits throughout the feast; indeed, generally speaking he was a man of the most abstemious habits, and never touched spirits. The writer has leard from one most likely best to know, that only once in his life did he taste a small quantity of spirits, but the alcohol had such an effect upon him, that he never repeated the experiment.

Who can tell what influence the fact of their captain's abstemiousness, and his taking nothing stronger than coffee during those dreadful days and nights of suspense-who can tell the influence that such an example may have exerted upon the minds of the crew? There have been many painful instances of sailors, when it has been made known to them that there is no hope, rushing to the spirit and wine stores, and meeting death at last in a state of intoxication; but on board the London there was nothing approaching to this. On the contrary, there was the strictest sobriety among the crew and passengers, and we cannot help believing that Captain Martin's example had much to do with it.

Such is a brief sketch of the man whose name will, for many years, henceforth be a household word for all that was enduring and brave amid the most distracting perils, and for all that was gentle and endearing among his relatives and friends.

He had served a tolerably long apprenticeship to the sea-his last voyage was his thirteenth to Melbourne as commander-and his reputation as Master of the Suffolk had been so brilliant, that in the forty-seventh year of his age, and at the end of 1864 , he was appointed Captain of the London, a vessel on which still greater care and cost had been expended than on the Suffolk, which he had so successfully navigated for upwards of eight years. The London was built in pursuance of the plan 
for steaming to Australia round the Southern Cape. She made two very rapid royages to Australia and back, and fully justified all the cost and care expended upon her construction. Her value, exclusive of cargo, was estimated at about 80,000l. Captain Martin's share in her may have been about $5000 l$.

The London was therefore on her third royage, and, commanded by a Captain whose good fortune had become almost proverbial, and belonging to a firm who, in their time, had never lost a ship, she set sail upon the voyage which was so soon terribly interrupted. But while she is yet in sight of Plymonth, we must call the reader's attention to one passenger who has gone on board, whose name will live as long as there are hearts to feel what is life-giving in the gospel, what is majestic in faith, and what is sustaining in death. We neerl scarcely say that we allude to the Rev. D. J. Draper.

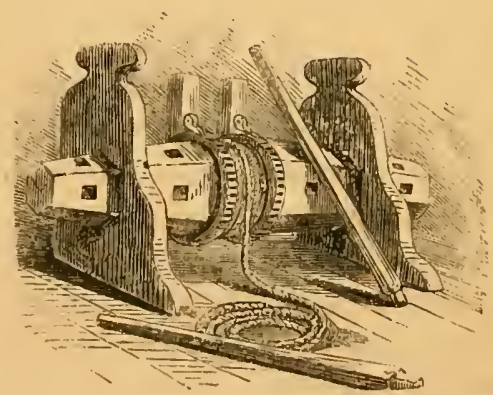




\section{CHAPTER IV.}

REV. DAXIEL JAMIES DRAPER.

Daxiel James Draper, a name that will henceforth be as honourably and widely kuown in England as it was previously in Australia, was born at Wickham, near Eareham in Hampshire, on August 28th, 1810. He was of respectable parentage, his father being the chief carpenter and builder in the village. Although unacquainted with the saving knowledge of the gospel, his parents were strictly moral in their lives, and regular attendants upon the services of the parish church; consequently the influences which surrounded the child's opening years were farourable to the formation and growth of virtuous habits.

He was brought, howerer, to religious decision by coming in contact with some deroted Wesleyans in the neighbouring village of Fareham. They had a chapel in the village, and in it the gospel was fervently and faithfully preached; and we doubt not the building-for it still exists-will henceforth be memorable on account of its being the place in which Daniel James Draper first saw the necessity of repentance towards God and faith towards the Lord Jesus Christ.

By the door of this chapel young Daniel was occasionally found listening, and taking in stray words of warning and of wisdom, as John Bunyan did before him from the lips of the pious women of Elstow, who talked of holy things as they spun and knitted in the sunlight before their cottage doors. Daniel would not enter, but again and again the lad was seen listening at the chapel-doors, and marvelling perhaps, like the 
tinker of Bedford, at what he heard. On one occasion he received a sharp rebuke for neither coming in nor going away, but only standing without, and the reproof so wounded him that he resolved never to go near the place again.

But to this resolution lie did not keep; and ere long, in this chapel, the truth of God was applied to his youthful heart, and he felt very deeply the need of salvation. Ontwardly in his life, hitherto, there had been nothing worthy of blame; his conduct had been strictly upright and moral; but now his conscience revealed to him depths of depravity and guilt, of whose very existence he had been unconscious, and he saw the urgent necessity of receiving pardon, and of becoming a partaker of the new birth. By repentance and faith he immediately sought reconciliation with God, and it was not long before he became a rejoicing believer in the Divine love and favour.

Very naturally, he now openly connected himself with those from whom he had received so much spiritual benefit, and he became an enrolled member of the IVesleyan Society. He had not reached twenty years of age, when, although still beneath the roof of his kind, church-going father, he took this decisive step. His resolution to connect himself with the Methodists was not favourably received by his father, or by the members of his family generally, but young Daniel held on his way; yet, as he did this with all the good nature that was so marked a eharacteristic of his maturer years, there is reason to believe that his youthful profession did not expose him to any opposition that pressed heavily upon the buoyancy of his spirits. He even in these early days became well known for the zeal and interest he displayed in the salvation of the lost and perishing.

Ere long the Methodists determined to erect a chapel in the 

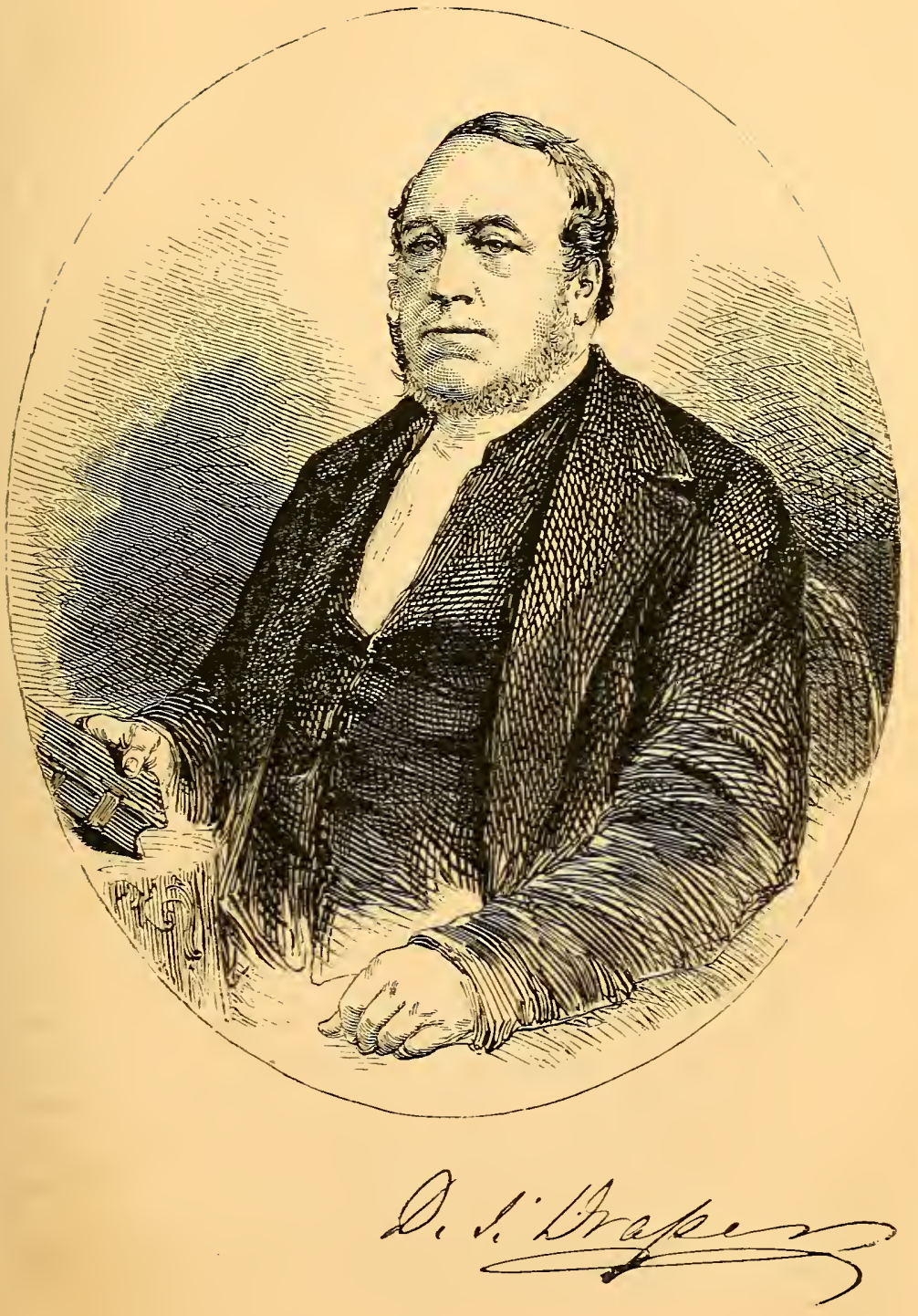

village of Wickham, where he lired, and it is interesting to remember now, that it was built by Daniel and his father, and that, in the course of a short time, the son had the opportunity, in that rery chapel, of proclaiming to his father the unsearchable riches of Christ s gospel. He was about twentr rears of age when he enjored this pririlege, his gifts and character haring placed him amongst the Wesleran local preachers. Although it was still distasteful to some members of his famils, he erentualls decided upon deroting himself to the work of the ministrr, and nerer was a decision, we beliere, more in harmony with the Dirine will and more signally honoured by blessed results.

When about twenty-two rears of age the roung preacher remored to Brecon, with its towering beacons, pleasani streams, and still pleasanter societies of Christian people. Mr. Draper is still remembered there with affection, and manr can call to mind his derotedness to Christ's serrice, his lore for the house of God, his familiaritr with the Scriptures, and his attachment to the prayer-meeting. A farourite hrmn with him in those days was the one in which this rerse occurs:

\section{"Happs, if with my latest breath \\ I mar but gasp his name, \\ Preach Him to all, and cry in death, \\ Behold, behold the Lamb!"}

At Brecon he worked hard, both in the culture of his own mind as well as in the serrice of his Divine Master. He read good and solid books, and through his life long the substantial was always more attractive to him than the glittering and merely artistic; he had no relish for a literature that did not help him in his work, and all he acquired in study he gare out in effort for the good of those amongst whom he lived. 
One can readily imagine his happy earnest life during these Brecon days, of dangerous mountain journeys to the stations where he preached; of open-air preaching by the river-side; of the welcome which the warm-hearted Welsh people gave everywhere to the young preacher, we can have no doubt. It was during this time that his sister, still living at Brecon, received the truth in Christ, through her brother's instrumentality. He was destined, however, for a larger sphere of usefulness than any which his own land could furnish, wide and urgent as its claims were and are.

While he was at Brecon, his character and gifts had so generally impressed several ministers and friends of his fitness for the regular ministry, that he was recommended to the Wesleyan Conference as a minister; and in 1834 he was appointed to the Chatteris Circuit, in Cambridgeshire, and here the same energy and zeal eharacterized his efforts.

At this time, the attention of various Missionary Societies was being directed to the spiritual wants of those who were settling in the colonies. Emigration was becoming more and more popular, and every week multitudes were leaving our shores in search of the fabulous fortunes which the colonies held up temptingly to their view. Gold, it was hinted, would one day be found in any quantities by men who would only have to dig for it; riches incalculable might be obtained in an incredibly short space of time. The directors of Missionary Societies were keenly alive to the danger that would accrue to the thousands who were going away from the religious altars of their own land to find themselves in a strange country, where the means of religious instruction were of the most meagre description, and where there would be the most terrible scope for the unbridled exercise of unholy lusts and passions. They were therefore 
diligently on the look-out for men of strong nerve and character, who could speak the right word to their fellows, amid the fierce excitement which burned within them;-men who could remind them of the hallowed association of their old homes, consecrated as they had heen by Sabbath and Bible, and, by the remembrance of these, woo them to an interest in those things which would be found important and lasting when all the gold of Australia should have lost its value. The directors found many such men;-men brave enough to remain poor, while thousands around them were becoming rich; men who, in their strong might of godliness, stood like so many breakwaters against the surging flood of sensuality, avarice, and full-blown pride, which, in the course of time, threatened to submerge the land.

Among the men to whom the attention of the Wesleyan Missionary Committee was directed was Daniel James Draper, whom they were told was well adapted for Missionary service.

Physically, he was a strong man; a man about the middle height in stature, vigorous build, honest open face illumined by softly shining eyes, and voice of full trumpet tone; a man capable of fatigue, one who could endure hardness; decided, resolute, cheerful, and withal gentle in every thing he did; liberal and catholic in his tendencies, ready to learn and apt to teach; and above all, a man of strong faith and devotion. When it was proposed to him to go abroad, he gave the matter a brief but very earnest consideration, and at length he intimated his willingness to obey the wish of the Committee, and at the same time to be obedient to what he believed to be the call of duty and the will of God. By this time he was a married man, his wife being the daughter of Mr. Webb, of Fareham; and the young couple prepared to set out for Australia. The young Missionary looked forward to his 
future field of labour with the calmest confidence, as he thought of the Divine presence accompanying lim, and that he was neither going away from his Saviour nor his work, because going to a distant land. He took an affectionate farewell of his family and many friends, some of whom accompanied him to the ship.

There are many yet living who can remember well the period of his leaving England, and all the circumstances attending it. He went away on the 13th October 1835, with the farewells of many devoted and noble men ringing in his ears, whom, in the providence of God, he was never destined to meet again. Jabez Bunting, among others, had given him every encouragement, and had said to him, "Years of labour may be before you, but success is certain: it must come, it must come!"-He left his native shores with those words animating his heart:- "Success is certain; it must come, it must come!" Never were words more prophetic of the success which awaited the young Missionary's efforts in the far-off land to which he was going. The voyage out was a dangerous one; the ship was overtaken by a violent storm, and at one time the Captain had said, that in six hours they would all be at the bottom; and thus shipwreck marked the beginning and close of his Missionary life.

Mr. Draper arrived at Sydney early in the year 1836, and applied himself to his work with all the enthusiasm and energy which were among his main characteristics. He could indeed speak conscientiously of "doing a week's work," for labour with him meant something, and was far remote from pretence. On Sunday morning he preached in the city, in the afternoon at a place fourteen miles off, and in the evening again at Sydney. Every day and every evening of the week had their engagements, which he perseveringly discharged; and while thus 
earnest in his own sphere, he was on the most brotherly terms of communion with the various branches of the church of Christ at Sydney and surrounding towns. He could truly say,

"Be they many or few, my days are His due, And they all are devoted to Him."

A large amount of success attended labours thus constant and conscientious; many, very many, will have reason to bless God for his ministry at Sydney. It was not without drinking of sorrow's bitter cup, however, that he had to commence his work amid new scenes and circumstances. He was early called upon to resign his young wife and child into the arms of death, and to feel the grief of a widower among strange people.

Subsequently his life for many years became subject to the changes incident to Missionary life amongst members of the Wesleyan community, and he was removed from station to station. It is gratifying to note, however, that he left no station without also leaving behind him the impress of a man whose one object it was to bring souls to God. In 1837 we see him pursuing his work at Paramatta; and from 1838 until 1841 at Bathurst. $\mathrm{He}$ is at Sydney again from the last date until 1845. He goes to Melboume in 1846, and he was there for twelve months, during all the excitement produced by the discovery of gold.

The following year, he removed to Adelaide, and continued there until the year 1854. In 1855 he once more returned to Melbourne, and travelled successively in the East circuit, the North and the South. He was not without honour from his brethren in the ministry, who, in 1857 , chose him to be Secretary of the Australian Conference, 
and, in the year 1859 , elected him to fulfil the post of President. In addition to his pastoral and other duties, we may also remark that he had deeply interested himself, being a man of some means himself, in getting a provision made for poor ministers and for the widows of such, and his benevolent wishes were partly accomplished.

Such, then, is a brief outline of Daniel James Draper's life, during a period of about thirty years in Australia. The details of those years of honourable service in the church of Christ will, if published, reved a life of no ordinary labour and no common success. But, if never published to be read by the eye of man, we rejoice in thinking that they are already known to Him who called him home, bade him rest from his labours, and left them to follow him.

In the year $1865 \mathrm{Mr}$. Draper determined upon once more visiting his native land, and the scenes of his childhood. It is said that the love of Home was very strong in him, and that like a magnet it would every now and then draw his heart towards his country and towards old Fareham scenes and associations. His parents were now dead, and many of the friends of his youth were gone, but still it would be good to see the old place once more. He had married again, his wife being the daughter of Mr. Shelley, one of the first Missionaries to Tahiti, who sailed by the ship Duff at the end of the last century. She was an amiable and accomplished lady, worthy of her parentage and worthy of her husband: we cannot accord her higher praise, or it should be freely given. Having resolved to revisit the land of his birth, he was not long in making all necessary arrangements, and accompanied by the best wishes of firiends at Melbourne, Mr. and Mrs. Draper sailed in the Great Britain, and, after a voyage, of sixty-four days, landed at Liverpool May 20th of last 
year. He had come to this country not only that his heart might be charmed by old and familiar scenes, and by intercourse with friends, some of whose faces he had never seen, but also in an official capacity. The Methodist Conference of Australia had desired him to be their representative at the British Conference, and his brethren in Australia had expressed themselves thus concerning him:"The Rer. Daniel J. Draper has our ready consent to visit the land of our fathers. By our unanimous wish he is commended to you as our representative in your next Conference. You need not be informed of his raluable services to us; his intimate knowledge of our Connexion; or the high esteem and confidence in which he is held. We beliere that from you he will receice a most affectionate welcome. He will be fullowed by our prayers, that he may return to us in health, and in the fulness of the blessing of Christ."

The welcome which his brethren thus bespoke for him he everywhere most cordially received. He preached in London, in Great Queen Street Chapel; he was at the laring of the stone of the Wesleyan chapel now being erected in the Caledonian Road; he preached in St. James's Hall, taking one afternoon the place of a minister who was unable to conduct the special service there; and he preached, last of all, it is believed, at Dalston, and afterwards administered the Lord's Supper with much solemnity.

As the representative of the Australian Conference, he attended the British Conference at Birmingham, and, with the same object in view, he risited Scotland and Ireland. At the sitting of the Conference in Birmingham, his modesty, his manly sense, his quiet earnestness, and his unaffected derotion called forth the general respect and admiration of the ministerial fathers and brethren present. $\mathrm{He}$ also visited 
some of the principal towns in England, and showed himself everywhere the courteous, kindly, and cheerful man, with a sound judgment and well-informed mind. As might have been expected, Fareham, the scene of his childhood and of his first efforts to preach Christ, was among the places he visited. He preached there, and had the grave of his parents attended to and beautified.

We have met with those whose happiness it was to come in contact with him during his stay in this country, and on all hands the testimony is, that he was a man as much beloved for the rich human qualities of his heart, as he was respected for his extensive practical knowledge of life and the world. One remembers his hearty cheerful laugh, another his telling anecdotes of Australian life, and another the simplicity and fervour of his prayers. One tells of the trouble he took to find out a young man in London, for whom he had been entrusted with a message of kindness; all can tell of the deep tender devotion of the man, untarnished by so much as a touch of fanaticism. One who was brought into close communion with him for several hours, about two or three weeks before he sailed in the London, has said:-

"I was much impressed by Mr. Draper's conversation and bearing. He had seen the world, and he talked like a man to whom men and things were familiar. The experiences of life had evidently accomplisher their purpose in him. He was in command of himself; his judgment was strong and wellbalanced; his tone and mamer altogether showed the completeness, the symmetry, and the tender and genial perfection of one who had laboured and suffered, and, in all, had grown wiser and better, and more serviceable for his generation and mankind. His centre could not be doubted. Christ and Christ's work, these were conspicuously the objects about 
which his whole thought and being revolved. Cheerful, pleasant, courteous, alive to all that was going on around him, utterly free from all sourness and affectation, he exhibited, with wonderful attractiveness, the simplicity, purity, dignity, and high and holy aims of the minister of Christ. His prayer at family worship I shall never forget. As he offered it, I could not but remark how the little child and ripe saint met in those natural, lowly, reverent, and calmly mighty supplications. It was the prayer of a man, between whose spirit and God there was no haze, and who was as sure of answer as if voices from heaven told him he was heard."

In November last he engaged a berth in the London. There were many who would have prolonged his stay in this country if possible, but Mr. Draper's wish was, now that he had accomplished the end for which he had come to England, to return to the land of his adoption. He was advised to go through Egypt, and indulge himself with a few weeks journey through the Sinaitic peninsula and Palestine, but he seemed even anxious now to return to his work at Melbourne. In one of his last conversations with the Hon. W. A. M`Arthur, who had expressed some regret at the shortness of his stay in England, Mr. Draper said, "Well, I could spend another year in England very pleasantly, and should like to do so if my conscience would allow me, but I feel I must get back to iny work."

"Little," says Mr. M'Arthur, "did he then imagine that his work on earth was so nearly finished, and that he was so soon to enter into the joy of his Lord; but if 'that life be long which answers life's great end,' then Mr. Draper has lived a long life; and having had the pleasure of his acquaintance upwards of twenty years, I can testify that his was a joyous, happy life, and that much of his happiness con- 
sisted in seeing others happy, and endeavouring to make them so."

And now we are in the track of the devoted Missionary, as he prepares to go on board the vessel which was soon to meet with a disaster terrible beyond many of the most grievous in the annals of shipwreck. Now that the agony is over, and the faithful one at rest, we are disposed to see a meaning in that dream-the story comes to us on good anthority-which, thrice repeated, bade him resist all the importunities of friends, and go by the London, and no other way, and we would not lave had him disobedient to the roice.

To a friend in Dublin he wrote, a few days before he sailed-"The steamer (the London) is a fine new vessel, having gone out but twice. Last time she did the voyage in sixty days. We join her (D. v.) at Plymouth on the 2nd January, and she will leave that port at six P. Mr, on that day. We trust in God our Hearenly Father for protection on our way, and delight in the thought that we shall be remembered by kind friends when they bow at the throne of grace."

And so the good, genial, loving man went away from the land he loved, notwithstanding the associations of thirty years life in another country; from his Hampshire home which was as dear to him now, though approaching sixty years of age, as when lie played there as a little child ; and from the newly doneup grave, where the dust of his parents was sleeping. At the lidding of his Master, into whose hands he had committed his entire life, he had mored from station to station in Australia. He laad never doubted the will of God in the successive. changes which liad marked his colonial life. He believed that there was a work for him to do in every place to whicl he was called, though he went to station after station, not knowing the things which were to befill him there. Shall wo 
donbt now that a voice in richest mercy towards others, summoned him to a station in which he was to do his last here for the Master who loved him, and who had need of him indeed for an awful service, but on which hung a reward and a blessing more glorious than heart can ever dream of?

We believe that he had only been a few days out when he felt this, and summoned all his energies rightly to discharge the duty his Master had called him to, to make his last, his best. Serenely committing himself to the keeping of a merciful and faithful Creator, Diniel Draper perhaps never thonght of his own wants, until he awoke up in glory, and found with sweet surprise that he had none, that he was in the likeness of his God, that he had exchanged corruption for incorruption, that mortality had been swallowed up in the deep, deep sea, and that around him were not shipwrecked mariners in their dripping garments and looks of agony, but faces bright with joy, and forms radiant with the glory of immortality.

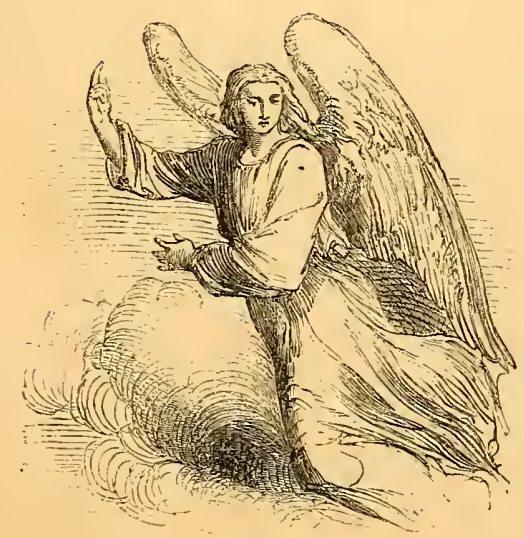




\section{CHAPTER V.}

\section{THE LIST,OF PASSENGERS.}

WE must pause yet once more before accompanying the royagers, that we may know as many of them as we possibly can. Many we perhaps shall never know: their very names are already forgotten; or if we turn to look at them they tell of no history, and suggest no personal remembrance. On such a day they were in the London, on such a day they sank with her in the Bay of Biscay. This is all perhaps we shall ever know concerning them.

A gentleman, who knew most of the passengers on board -and we give an authorized list of the names in the Appendix-when he heard of the catastrophe, remarked, that it would throw half Melbourne into mourning. Doubtless it will, and into how many other places besides will not the news of the catastrophe carry mourning? That one poor Bararian, those two hapless Danes, had they no friends in the world to shed a tear over their watery grave? We dare not forget that each one, as he embarked, carried within him, as it were, a very world of varied interest, and that the hopes and sympathies of the unknown and poor were as precious and beautiful to those who knew and loved them, as were the plans and fortunes of the well-known and wealthy to the circle of which they formed part. Every death we see recorded should bring before us, in imagination, a bier, aromnd which we see gathering a collection of mourners, refusing to be comforted, because their lored one is not. When we hear of a multitude of persons perishing in some dread calamity like the present, we must remember that, while all died together, 
each died alone, and will be mourned as if he alone had died. More than two hundred individual worlds of thought and feeling, of sympathy and design, went down beneath the ocean wave on that wild stormy afternoon. Each of these worlds was perhaps the very sun of other worlds, that will now receive a sudden and awful shock. Many men, many poor men eren, so live that they are centres of operations which, although not brilliant in the world's estimation, are of the deepest possible interest to all concerned in them, and when they die, it is as if the sun had been removed out of its place.

Nor do we forget, as we take up the list of passengers who went out in the London, that erery one had a separate and solemn history. We do not forget that the issues of life were unspeakably important, not only to all, but, in a rery solemn manner, to each-to the poor Danish sailor as well as to the Oxford scholar: we do not forget that to each one on board, this question was proposed amid circumstances most appalling, "What shall it profit a man if he gain the whole world and lose his own soul, or what shall a man give in exchange for his soul ?:" We dare not forget the infinite value of every soul on board.

As, during the week which followed the mournful announcement that the London had foundered, we looked each day into the first column of the Times, or as country newspapers reached us, we tried more and more vividly to realize how much that list of the drowned meant, and how names that we had read confuselly amidst a mass of others, became eloquent with interest as we caught snatches here and there of the lifehistory belonging to them. But we have no doubt that there was not one on board whose history was completely destitute of interest and charm, to some few at least, and that tears hare been shed for many who were nothing more than plain, 
humble people, getting an honourable living by the sweat of their brow, and who will find no liographer to tell the unassuning story of their lires. In the scores of shipwrecks that occur every year, the worthy unknown should not be without the sympathy, if they are shut out from the recognition which well-known names immediately demand. Of late years, perhaps, if we may judge from the newspapers, from letters which have reached us, and from interviews with friends of the deceased, there las not often been a wreck in which such a raricty of characters had each to act a most solemn part. On board the London there was life begimning and life ending in the aged and the young who were going out to the new land. There was the competence which had come after arduous and successful toil, and there was the poverty whose only capital lay licdden in its hopeful industry: there was the lawyer and the divine, the merchant and the engineer, the man of letters and the rude brawny artisan; the actor and the banker; the experienced traveller and the humble villager from Cornwall. Something of the varied life of the world at large lay mirrored in that vessel that was preparing to steam away from Plymoutl. The brief notices of deaths which appeared day after' day revealed dark depths of sorrow, into which one was almost afraid to look,-tragedies enacted full of horror unspeakable.

Let us glance for a moment at those of whom we know nothing beyond their names, before proceeding to notice those whose position in society and whose well-known histories speedily found biographers.

On the 11th inst., lost at sea, on board the steamship) London, James Thomas, Esq., late of London, formerly of Huddersficld, Yorkshire, together with his beloved wife and 
two children; also Elizabeth Hartley, for many years a most faithful servant of the above.

On the 11 th inst., lost at sea, in the steamship London, aged 23, John Ruskin Richardson, youngest son of the late John George Richardson, Esq., many years a resident of Sydney, New South Wales.

On the 11th instant, in the steamship London, in his twentyfirst year, Archibald, seventh son of Hellen Sandilands, of 56, Belsize-park, and of the late John Sandilands of Conduitstreet.

On the 11th instant, lost at sea, in the steamship London, on her voyage to Melbourne, Gilbert Andrew Amos, Esq., Police Magistrate and Warden, Heidelburg, Victoria, and third son of the late Andrew Amos, Esq., of St. Ibbs, Hitchin, Herts; also, at the same time and place, Isabella Dick Amos, wife of the above; also, at the same time and place, Miss Catherine McLachlan, aged 22, sister of the said Isabella Dick Amos.

On the 11th inst., in the steamship London, on her voyage to Melbourne, Edward Youngman, Esq., aged 44, greatly beloved and regretted by a numerous circle of friends.

On the 11th inst., lost at sea, in the steamship London, George F. P. Urquhart, Esq., of Evandale, Auckland, New Zealand, and Mary Chauncy, his wife, late of 11 , Kensington-park Villas, W., daughter of the late Major James Burke, of the 77th and 99th Regiments, of Arlaman, county Limerick, Ireland.

These are only a few instances out of many that might be given; but now to look at names, well known, take first the story of the Cumberland emigrants.

It appears that no less than ten persons who went out in 
the London were connected with Cumberland; one family, consisting of William Graham, his wife, and three children, having gone from Carlisle. It is a sad story-one which cannot be read even by strangers without the nost sorrowful feelings. William Graham, tailor, aged 51 years; Ellen, his wife, 49 years; George, his son, 10 years; a daughter, 3 years; a baby, aged 4 months; Thomas Graham, aged 40 years; Mary, his wife, aged 27 years; David Graham, aged 37 years; David M'Vittie, aged 30 years, blacksmith, Newtown; and Joln Little, aged 30 years, fireman on the North British Railway. 'The three Grahams were brothers. Thomas had been out in Victoria twelve years, and David followed him four years afterwards, and had since been engaged in business with him. Success followed their farming operations, until they were enabled to purchase an estate. In their prosperity the brothers were not ummindful of their old home, and during the prevalence of distress at Longtown, in consequence of the cotton famine, they generously sent over a sum of $60 l$. for the relief of the sufferers. They also sent a large amount of relief to Manchester. In August last they came to England, with the view of seeing their friends, and of purchasing implements. Upwards of $1000 \%$. they laid out in this way, and sent out before them a variety of implements for the farm. Thomas had another purpose to effect, also, in visiting the old country, and that was to marry, and take home with him a wife. He married Sarah Bruce, a native of Banff, and they were married only a week before they left Carlisle to take up their berths on board the Iondon. Their brother, William Graham, agreed to go out with them, they paying lis passage, and he took with lim lis family, as stated above. Little and M'Vittie, friends of the Grahams, were also going out with 
them. Both men were in the employ of the North British Railway Company, Little as fireman, and M'Vittie as a blacksmith. Little was a remarkably steady and amiable young man. He was the eldest of a family of eleven children, and is survived both by his father and mother. The whole party of emigrants left for London on the $2 \%$ th of December last, and a large number of friends assembled to bid them farewell, and three hearty cheers were given as the train started. Such were ten at least who had each a history inestimably precious to a wide circle of friends at home and abroad, and, simple though these people were by the side of more brilliant names, there is a quiet naturalness about their story that will appeal to many hearts.

On board the London also was Mr. Henry Joln Dennis, a gentleman of some note in Australia and America. A few years ago $\mathrm{Mr}$. Dennis narrowly escaped shipwreck in the Marco Polo, a vessel that in speed and celebrity used to compete with the Suffollk when Captain Martin commanded her. In the middle of the night, in the Southern Ocean, the Marco Polo struck an iceberg; but on that terrible occasion Mr. Dennis had been of some service. He had since been a very active colonial explorer, and had for many months been engaged in a hazardous hunting expedition in the wild regions and among the savage tribes which lie at the back of Port Natal. He is understood also to be the first, if not the only Englishman who lias grown cotton in the Southern States of the American Union by free negro labour. Starting for America while the civil war was at its height, he took a plantation on the Mississippi, and though he had to cope with plundering bands of guerillas and with many other dangers and inconveniences, he nevertheless succeeded in raising a crop, and only retired when he found that in the then existing 
state of things it was utterly impossible to grow cotton without great pecuniary loss as well as personal risk.

There was a clergyman on board, distinguished for his many and raried gifts, and who was belored by a very wide circle of friends, both in England and Australia-the Rer. Dr. Woolley, to whose wortl and talents Dean Stanley and Sir Charles Nicholson, formerly Speaker of the Isegislative Assemby of New-South Wales, have paid the very warmest tribute, as, indeed, have a host of the scholarly and wortlyy of the land. Dr. Woolley was in the 49th year of his age, and his course in life had been one of usefulness and honour in the branches of learning to which he had specially devoted himself. His life had been that of the Professer rather than of the working clergyman. He matriculated at University College, London, but subsequently remored to Oxford, where in 1836 he took a first-class degree in classics. On leaving Oxford, he became successively Head Master of Rossal Scliool, in Lancashire, and of King Edward's Grammar School at Norwich. This last office he relinquished on obtaining the appointment of Professor in 1852, in the University of Sydney, which had just been incorporated under an Act of the local Legislature. His duties in this new position were most important, as "pon him derolved the organization and successful working, under circumstances of great difficulty, of a great national institution. But he threw limself into the work cast upon him with enthusiasm, and laboured with untiring zeal and energy: He succeeded in a very marked degree in winning to himself and moulding the taste and character of the young men placed under his control. The gentleness-almost feminine-of his nature, the warmth and generosity of his heart, lis distinguished attainments as a scholar, and the eloquence and carnestness with which he was wont to impart instruction, not 
only to the Undergraduates of the Unirersity, but to the member's of various popular institutions with which he was conilected, have been tenderly spoken of, and will be long remembered by hundreds of persons. He came to this country a few months ago for rest, and very pleasant to himself, and to those who knew him, was his brief sojourn here. From many, as we at least read the matter, there came tempting inducements to settle down in England among associations more consonant with a refined taste than those of colonial life; but with him, too, the mainspring of life was obedience to duty, and he must return to the work waiting to be done by him. He had been exceedingly happy here. A writer in Macmillan says that one who saw him during his latest days in England writes of him thus :-

"His tastes were those of a refined and cultivated man. He told me that his stay here, mixing in the society of men of letters, had been a delight to him beyond what I, who was always in it, could conceive. Had he met Tennyson and Browning, nothing could be more to his taste than the companionship of such men, with whom his own qualities made him a most welcome guest. He harl in perfection the bright, gentle, cheery manner that characterizes the best Oxford man. In stature he was small, but his face most pleasant to look at. He was very active in all sorts of societies and institutions for the benefit of working-men and men engaged in business. His age must have been about fifty, but he looked younger. He had a wife and six children waiting his return to Sydney, whither, as I perceived, he was determined to go, for he felt his work lay there, and his duty. He went back to fulfil his duty, and has fulfilled it. He is remembered by many whom he left in England as the good man-John Woolley."

There was another passenger of celebrity on board-Mr. 
G. V. Brooke. He was of respectable family, and some members of it were highly distinguished in literature. In early boyhood he had been a pupil of Lovel Edgeworth, the brother of Maria Edgeworth. His father, who was an architect, had other views concerning him than those which the son lived to fulfil. He was edncated with a view to the bar; but while quite young he was thrown amongst those who were devoted to private theatricals, and he was so captivated that he relinquished his law studies and applied himself to theatrical pursuits. He met with some successes, and many reverses, particularly in Australia. Of all places in the world, after his many ups and downs in life, on the morning of the 6th Jamuary he was on board the London, and his sister was with him.

We had written thus far when there came a note from a surgeon, saying that if we would call in a street near the General Post Office, information of an interesting character awaited us. It concerned the loss of those of whose death there had been no advertisement-Mr. and Mrs. Clarke, with their son, a young man of twenty-one years. The mourning garments, the pale, sunken look of woe, the open photographic album, near to which were black-bordered notes, told at once of some one lost, and of tears shed, of which few had taken notice. $\mathrm{Mr}$. Clarke had gone to Melbourne more than thirty years before, accompanied by his wife and two or three children. He had prospered there as a saddler, and as the years went by, he was enabled to bring up a large family in every comfort and respectability. There was born to him a son, however, who unhappily, through a diseased bone, had a useless arm. The sight of the youth's sufferings was always painful to his parents, and so it came to pass that last year the aged people, as they wore now, determined to come to 


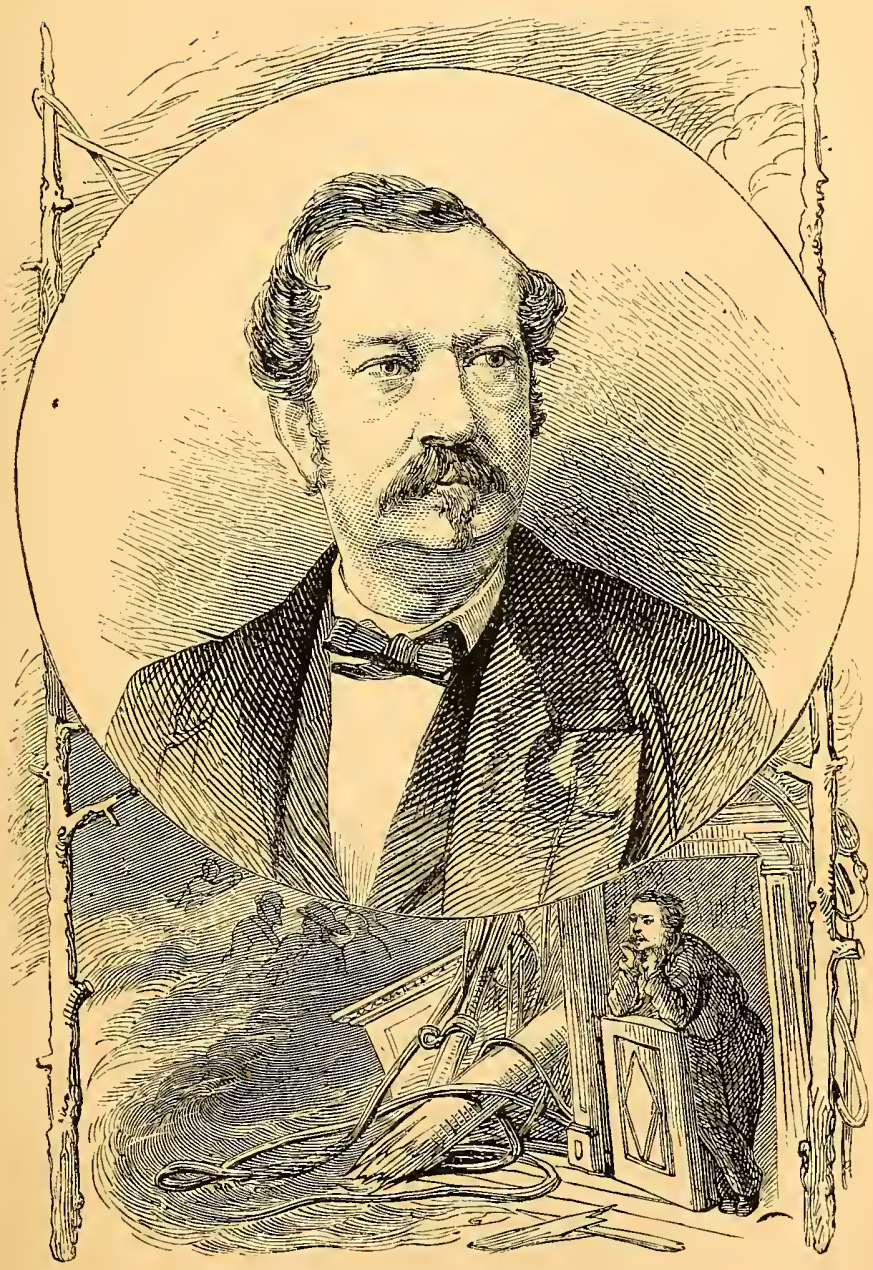

G. T. BIOOKE. 

England to obtain the best advice. Money was no object, and they reckoned that for about $£ 1500$ the three might come and go, and perhaps the son be cured. They came, enjoyed themselves immensely, heard preachers of whom they had often heard but never seen; went about here and there; and, best of all, under an operation performed by Sir W. Ferguson, the son's arm was cured, and made whole as the other. Mr. Clarke would have taken back with him a brave little boy, around whose neck we saw the arm of a mother fondly thrown, as if she wonld thus keep the child safe. He would have made the boy's fortune his care out in Melbourne; but the mother kept her child; and Mr. and Mrs. Clarke, and their son, rejoicing in his recovered strength, went on board the London, to be met on the other side of the sea, as they hoped, by their children and grandchildren. Before sailing, the father wrote a letter, the last words of which were a prayer, and it was with inexpressible comfort, in the midst of grief, that the relatives of the family reflected that the three were not unprepared to die.

Week by week will reveal more and more of the preciousness of those on board to those who now mourn their loss. But the story will never be completely told. Numbers will be mourned in secret, of whom we shall know nothing until the sea gives up its dead.

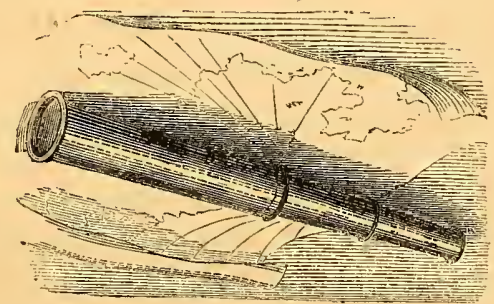




\section{CHAPTER VI.}

THREE DAYS AND NIGHTS OF DANGER ON THE DEEP.

WI'TH her precious freight of human life on board, the London left Plymouth in the very early morning of Saturday, January the 6th. A sailor's superstition had been respected, some would say, and the anchor had not been hove up until a short time after midnight of Friday; so that it was really on a Saturday that the vessel set sail. The weather was then moderate, the wind blowing lightly from the northward, and little or no sea running. The breakwater was cleared, and the ship proceeded on her voyage at the speed of about eight linots an hour: she was going under steam with head to wind.

They sighted the Lizard lights about four hours after they set sail, and the weather then was calm and fine. But an hour later, at six o'clock on Saturday morning, the weather changed: the wind veered to the westward, and the sea began to rise. It is important to bear this in mind, because of the criticism which has been applied to Captain Martin leaving Plymouth when the barometer was indicating stormy weather. One after another of competent witnesses examined affirmed most positively that the barometer was so shifty that it could not be relied upon, and that the weather was as favourable as any one could desire for going to sea. And even if the weather had been threatening, to have asked Captain Martin to put back on this account, would have been asking him to throw away the reputation which it had taken years to acquire, and to have acted in opposition to the practice of the most experienced seamen of the day. 
On Sunday, January 7 th, the wind, which was still westerly, increased in violence, and there were strong squalls and a heavy sea, in which the ship rolled considerably. Religious service was of course held on board, and it was conducted by Dr. Woolley and Mr. Draper.

It was not until Monday, the 8th, that the passengers began to feel anxious concerning their safety, and to regard their position as becoming every hour more and more perilous. During Sunday night it was evident that a gale might be expected, and on Monday morning it was blowing with great violence. The Captain ordered the engines to be stopped and sail to be made on the ship. Towards noon the wind appeared to lull somewhat, and in the evening the weather had so improved that all sails were taken in, and the engines again set in motion. The weather, however, soon changed again, and the gale seemed only to have lulled to gain new strength; for between eight and twelve of Monday night the spanker of the ship was blown away by its violence.

Captain Martin and some of the crew, amongst whom was the gallant John King, one of the survivors, endeavoured to get the spanker in, and at last succeeded. It was a night of raving wind and rolling sea, and we hear of sleepless passengers below in their cabins reading the Bible to each other, and offering solemn prayer to Him who rode upon the wings of the wind. All that night Captain Martin was here and there throughout the ship-indeed he was to sleep no more until the dreadful afternoon of Thursday - and all the orders which he gave were speedily executed by the crew. The wind was blowing a full gale, and mizenstaysail and forestaysail and maintopmaststaysail and reefspanler had beenset.

On Tuesday morning, January 9 th, commenced that dismal series of disasters under which eventually the noble vessel 
succumbed. 'The wind was blowing a hard gale from the S.W. and there was a very heary sea. The ship was now making little more than two knots an hour, as her speed had been reduced, and slie was going through the water under steam only. She pitched tremendously, and every now and then whole seas dashed orer her bows. Such was the state of things early on Tuesday morning; but the passengers helow as yet only heard the fury of the storm without; they were safe and dry in their cabins: the fires burnt brightly in the engine-room, and the two engineers, Messrs. Jones and Greenhill, surveyed with satisfaction the strong hatchway which protected their engines from the seas which broke wer the ressel. Bearing in mind what we have said concerning the size of the engine-room, the reader will be prepared to learn, that if that engine-room were flooded with water, the ship would undoubtedly sink. There needed no other accident than this to secure the shipwreck of the vessel. The officers on deck could comfort themsclves with the assurance, that thongh exposed themselves to the storm and heavy seas which broke over the ship, their passengers were safe, and they would, by the help of their good engines below, slowly plough their way through wares that looked as if they would roll mountains high.

At seven o'clock on Tuesday morning an unusually heary sea broke into the lifeboat stowed on the port-quarter, filling the boat and carrying her away, with all her gear. This was deemed a most melancholy occurrence, and a scries of minor disasters followed. At nine o'clock the ship gave a tremendous pitch forward, as if she were about to bury herself, prow foremost, and in a moment afterwards the sea, with a force that made the hardiest seaman quail, tore away the jib and flying jibboom, which carried away with them the foretop- 
mast, the foretopgallantmast, foreroyalmast, and mainroyalmast, with all their spars and sails, and other gear. Portions of the wreck fell clattering on the deck, or hung suspended by the rigging: the topmast was swinging in the rigging and the foreroyalmast was hanging down and swinging with the motion of the ship. The jibboom was lying on the starboard bow, right over in the water!

Thus, at one fell stroke, the beautiful vessel had been dismantled, and received damage which, in the storm that then raged, it was next to impossible to repair. Captain Martin was cool and self-possessed in the midst of the untoward occurrence, and efforts were at once put forth to remedy the disaster, but to little purpose. The masts which had fallen on board, and which hung suspended by their rigging, and the jibboom, which was fastened to the ship by stays of wire, could not be got clear; and thus it was, with the ship in this dismantled condition, with the gale still increasing in fury, and with a sea that kept constantly washing all forward, that the passengers and crew of the London steamed slowly ahead through the awful night.

There was little sleep on board that night, we may be sure. The devoted Mr. Draper had already begun the work of directing the minds of the passengers to Him who had promised to be a Refuge from the storm, a very present help in every time of need, and already we hear of earnest prayers offered for all needful grace to support the bitterness of the calamity. We know now, and it is a great light shining in the midst of the darkness, that there were many Christians on board, who, in the hour of peril, would be enabled to point the distressed to the simner's Friend. We can scarcely go in any direction throughout the metropolis without hearing the glad tidings of one, and another, and another, being on board, who 
would not be afraid to die, and who would be sure to be of nse to shrinking and, perhaps, unprepared fellow-sufferers. And in the cabins below it is very beautiful to hear the voice of supplication mingled with the din and war of the tempest. We hear at least of a few, who, in the second cabin, were engaged throughout the night in reading the Bible by turns. Mrs. Price, Mrs. Wood, who had with her her husband and five children, Miss Brooker, and Miss Marks, are among those thus engaged. Throughout the vessel the feeling lias gone forth that the passengers may never reach land, and may at any moment be called upon to exchange time for eternity. Thus the long dreary night of Tuesday wore away, and Wednesday came, bringing with it disasters that quickly rivalled each other in horror.

Early on Wednesday morning, about three o'clock, Captain Martin ordered the engineers to get up full speed, as he intended to put the ship about and run for Plymouth. The gale continued blowing without the least abatement, but in the course of a little while the dismantled vessel was once more homeward bound. Mizenstaysails were set, and she steamed N.N.E. at the rate of five or six knots an hour.

The chief engineer, Mr. Jones, is obliged to give up through sickness, and now it is Mr. Greenhill, the second engineer, who las to carry out the Captain's orders in regard to the engines throughout the day. The engines are in perfect working order, and although the vessel has shipped a little water through the number of seas that have broken over her, there is none in the engine-room, and the brass-bound and grated skylight abore is perfectly safe. There is not a crack in it that he can see, and, with the engines revolving more quickly now, away the vessel is steaming, head to the wind.

In the course of the morning the damage of the preceding day 
was repaired, so far as securing the masts, which, up to this time, had been swinging about aloft, and the wreck of the jibbooms cleared away from the ship. At noon an observation was taken, and indicated their position to be lat. $46 \cdot 48 \mathrm{~N}$., and long. 8.7 W., viz. in the Bay of Biscay, and about 200 miles S.W. of Land's End. As thcy hoped to make Plymouth soon, and to refit there before proceeding on their voyage, no repairs were attempted, save making the wreck as trim as they could.

Meanwhile, we have to say again, the fury of the storm increased, and the waves were running mountains high. It was six o'clock on Wednesday evening, and their course was N.N.E., when the wind increased into a perfect hurricane from N.W., the squalls blowing with a degree of fury seldom paralleled. The vessel rolled and pitched fearfully, shipping every now and then large quantities of water. Suddenly the fore and mainstaysails were violently torn away by the squall, and went flying away into the darkness. Shortly afterwards, the lifeboat and cutter, which were stowed away on the starboard side, were stove in and carried away by the violence of the sea. As the night deepened, and nine o'clock approached, the ship was in a hurricane, the like of which the oldest seaman on board had never seen!

The engines had been stopped, and the Captain was relying now upon his sails to bear him through, but they were blown to shreds and ribbons, and the once stately vessel, so strongly built and so perfectly equipped, was now the mere sport of winds and waves. In a few hours those on board had, if the storm continued, received an irreparable loss, for three out of seven of their boats had been carried away by the sea. Their two lifeboats, that would have held so many, and would have perhaps taken them in safety to land, were gone. Neverthe- 
less, Captain Martin was not the man to indulge in feelings of despondency, or to waste time in useless regrets. A solemn responsibility rested upon him, and we believe he was true to it if man ever was.

"Set the engines going, and keep her head N.N.E." "Ay! ay! Sir."

And on through the wild dark night and surging sea the poor London drove; when disaster upon disaster fell upon her with crushing weight. At half-past ten a terrific sea broke over the port-gangway, and what the sailors graphically called a mountain of water descended almost perpendicularly over the hatch of the engine-room. That hatch, as we have already said, was deemed strong enough to keep out any sea that might ever dash orer a ship. Altogether it weighed about a ton and a half, and it measured $12 \mathrm{ft}$. by $9 \mathrm{ft}$. It was glazed with plate giass half an inch thick, and there were gratings of galvanized iron over the glass, and the bars were three-quarters of an inch thick. Yet, although thus strongly built and brass fastened, that mass of water, which descended almost perpendicularly, dashed through the hatchway, down which it threw violently two men, and, literally smashing every thing in its way, immediately flooded the engine-room with water.

Mr. Jones, the first engineer, ill though he was, immediatcly ran from his berth, and descended to the engine-room, where he found Mr. Greenhill standing by the engines. The engineroom was flooding, and a body of water was passing down the hatchway. The hatchway had been swept clean away, and there was now nothing to prevent the rushing in of the sea. Of all calamities, this was the one most to be deplored: the ship's carpenter could do nothing in the way of repairing, and yet down they must all go, and that speedily, unless something 
was done, for at every sea the vessel shipped, the water in the engine-room was rising higher and higher.

To remedy the evil as far as possible, tarpaulins and canvas were brought, which the men tried to nail down over the aperture. The men also tried to put the flying jibboom over the aperture, but such a hurricane was blowing, that both the canvas and the men who were trying to batten it down were washed away. The pumps were set to work, and passengers and crew worked incessantly, some at the pumps, and some in baling out the water, which, alas! came pouring in, and which, notwithstanding all their efforts, rose higher and higher in the engineroom. Nor could they by any means cover over the opening which the sea lad made by sweeping away the hatchway: tarpaulins, blankets, sails, mattresses, whatever they conld find, they heaped upon ladders, pieces of wood, and spars, which they had thrown across as supports; but the storm and sea mocked their best endeavours; and, alis! about a quarter past eleven o'clock that night the waters had risen to such a height that the fires were out, and consequently the engines ceased working. There was already about five feet of water in the engine-room, and the ship was labouring heavily in the trough of the sea. Her condition, therefore, was altogether hopeless. In consequence of the engines stopping she conld no longer lope to steam through the gale; the engineers could work no longer, and, for the same reason, the large bilge-pumps were rendered useless.

Mr. Greenhill had the painful task of making known to Captain Martin the saddening intelligence that his fires were out, and that no more help was to be looked for from the engines. The Captain received the news with perfect calmness. He said he was not surprised at it; that he had expected it; and immediately ordered the maintopsail to bo 
set, in the hope of keeping his ship before the wind. Vain attempt. The gale tore it to ribbons, and in the trough of the sea the vessel laboured through the night, rolling gunwale under. Well, indeed, might the Captain say that night, "You may say your prayers, boys." It was a seaman's way of saying, "You must prepare for the worst: at any moment we may go down." It was indeed a time for prayer, and we believe that, during that night, of which we shall have a little more to say in another chapter, such prayers were offered as were perhaps never offered in sinking ship before.

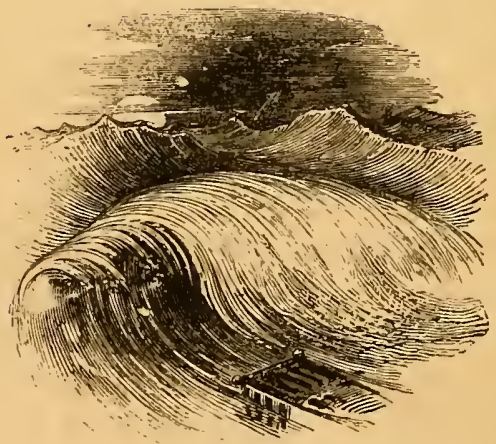




\section{CHAPTER VIT.}

LAST STRUGGLES.

THE morning of Thursday, January 11th, at lengtlı came to the passengers and crew of the foundering London. There had been, we may be sure, no attempts at seeking rest among the passengers below. On the deck all night the pumps had been going, and every one was doing his utmost to second the good Captain's efforts to save the ship, if possible. The bravest had little hope of this, but still every man worked as if all depended upon his efforts. The universal testimony is, that passengers and crew did what they could. Some of the crew, it is true, had to seek their berths through sickness or terror; but there was no lack of hands to work the ship.

There was no abatement in the fury of the storm; the wind raved as violently and the waves thundered as fiercely as ever against the ship, and there was no change in her monotonous roll in the trough of the sea. It was the morning of that fearful night, it may be remembered, when more than thirty vessels were driven on shore in Torbay. The names of some of the passengers of the London who strenuously exerted themselves have been made known, although they have not come back to hear of the enthusiasm which their gallantry has inspired in the hearts of thousands. Dr. Woolley worked with the rest at the pumps, and encouraged the passengers to do their best: he, though so delicate, and all unused to manual labour, did his work with the bravest and best of them.

The exertions of $\mathrm{Mr}$. Brooke, if possible, surpassed those of any on board. At times he went into the saloon, where his sister was among the ladies, and where, in frightened groups, 
the passengers were engaged in prayer, in reading their Bible, or in listening to the instructions and consolations of $\mathrm{Mr}$. Draper. The tragedian would help for a little while in baling out the water, and then he would away again to the rleck to work at the pumps, and he continued so doing until even he had to relinquish all hope. Barefooted and bareheaded, attired only in a Crimean shirt and trousers, now in the cabin-now on deck-he forms a picture of dauntless heroism that will long live tenderly in the memory of his friends.

It was about four o'clock on Thursday morning when a new disaster occurred, which, added to the sweeping away of the hatchivay on the preceding day, may be said to have sealed the fate of the vessel. A tremendous sen struck the stern of the ship, and stove in four of the windows of the upper or poop cabin. Through the breaches thus made the water rushed in, and the 'tween decks were soon flooded. The carpenter was immediately set to work to remedy the disaster, and he found that the force of the sea had driven back the strong shutters of the dead lights, and broken the glass of the sashes insicle, and the sea was pouring in in great quantities. He endeavoured to secure the ports by shoring them with a spar placed against a post on the main deck, so as to make the shutters once more firm, although the sashes had been driven in. The stratagem succeeded for a little while, but as the ship got deeper in the water the sea drove the ports entirely in, and soon rushed about unchecked through the upper and into the lower saloon.

Meanwhile, on deck the efforts of both passengers and crew were directed more earnestly than ever towards keeping the gaping aperture over the engine-room covered. The ship was fast settling down, and was more than half full of water. Captain Martin went down with Mr. Greenhill into 
the room, and, upon the engineer taking soundings it was found that there were fourteen feet of water, the whole of which had come through the hatchway, notwithstanding all the efforts made to keep it out. There was also a considerable increase of water between the decks. Every time the ship lurched in the trough of the sea she was taking in tons of water over the gunwale. Captain Martin did not lose heart, but at the same time told Mr. Greenhill that he had now little hope of saving the ship. Nevertheless, upon going on deck, after this examination of the engine-room, he cried to those who were baling out water, "Men ! put down the buckets and come and try to secure the engine-room hatch, for that is the only chance to save the ship. Secure that, and we may keep her up."

Instantly the Captain's order was obeyed, and once more the men tried to nail down sails and tarpauling, which the sea, however, washed ruthlessly away, or flapped down into the engine-room. Among those who laboured hard at this work, useless though it too soon proved, was John King, who had been hurt the preceding evening by his fall overboard. The violence of the sea and storm was such, that men were driven hither and thither by it on deck, knocked against casks and pieces of the wreck, and were in imminent danger of being washed overboard, as King had been. But there was no relaxation of effort. Mr. Angell was at the donkey-engine, Dr. Woolley, Mr. Brooke, and other passengers at the pumps, and many were engaged in vigorously baling out the water from the lower saloon, through the upper saloon, and over the upper deck.

All'efforts, however, were unavailing. Mr. Wilson, one of the survivors, said, that as it was getting light, he asked Captain Martin if he should go on baling out the water, to which the Captain replied, "You may, but I think it is of no use." 
About eight o'clock the carpenter received orders to see to the boats! On board now there were the port cutter, the two pinnaces, and the jolly boat, for two lifeboats and the starboard cutter had been washed away previously. All the boats were immediately plugged and made ready for sea, and bread and water put in them. A little before ten o'clock the starboard pinnace, which was of iron, and which would hold fifty persons, was got ready for lowering, and John King with five others got into her. Being lowered too fast, however, she swamped, and sunk headforemost: the men were of course thrown with great violence into the sea. After having been twelve seconds under water, King was washed up to the rail of the ship, and grot on board, and the rest also were sared.

Shortly after the foundering of the starboard pimnace, the Captain entered the saloon, and said, by way of answer to the mute appeal made to him on every face, "Ladies, there is no hope for us, I am afraid. Nothing short of a miracle can save us." These were his exact words, and Mr. Draper calmly replied to them by saying, "Then let us pray!"

At two o'clock on that wild, stormy afternoon the vessel was sinking rapidly, and the channels were nearly level with the water. Captain Martin now told Mr. Greenhill, that as the port cutter was ready for lowering, he had better take the command of her, and of as many as it would hold. As for himself, he had no thought of leaving his ship; he would sink with the London and her doomed passengers. The crew, as they remembered the fate of the starboard pimace a few hours previously, were at first not over-anxious to set about lowering the port cutter, and, for reasons that will appear in the next chapter, the passengers generally made no attempts to escape. 
John King, with a few other seamen, had already provisioned the cutter with a bag of bread, a beaker with about a quart of fresh water, and a few bottles of brandy, which a bright and intelligent young midshipman, Walter Edwards, greatly to his credit, as Mr. Traill the magistrate observed at the Board of Trade Inquiry, managed to conceal from the men after he had got on board. A few here and there could not see an attempt being made to escape, notwithstanding its seemingly hopeless character, without being desirous of joining in it. This lad, who was on his first voyage out, said, that after the starboard pinnace had been swamped, he heard Captain Martin earnestly dissuading a lady, Mrs. Owen, from going in the port-cutter boat. He himself was talking with Mrs. Orven when the Captain came up to where they were. She told him she intended going, and had asked one of the men to take care of her and her little child, and the man had promised to do so. Captain Martin, as if he knew of the spirits that had been put on board the port cutter, told her earnestly that there might be drunken seamen in the cutter, and that she would only be exposing herself, perhaps, to a painful and lingering death.

"Captain Martin," said the lad gently, "was quite calm and composed. The only time I saw him give way was when he told Mrs. Owen that there was no use in her going into the boat: his feelings then quite overcame him, and he cried. All the officers of the ship worked well. The sailing-master, Mr. Harris, was working all day on Monday and Tuesday with his coat off, and $\mathrm{Mr}$. Grant also behaved exceedingly well. They were all attentive to duty, and had not lost their mind up to the time when the ship went down. All the passengers, you could see, had death in their faces." 
"And what were your own thoughts, you brave young Walter ?"

"I felt for leaving my mother, but I did not feel any fuar" about going down. I felt some fear on the Monday."

"But you got accustomed to it, I suppose?"

"Yes."

"What else do you remember?"

"About twenty persons stood watching King and Daniell getting the port cutter ready; but King and Daniell induced them to go and try to launch the port pinnace. Botlowent to help them to do so, but as soon as they got them engaged at the pinnace, King and Daniell slipped away, and were busy about their own boat again."

"And how did you get into the boat?"

"I was in the mizen-shronds. I asked King and Daniell would they allow me in, and they said 'Yes,' and bid me jump. I did so. The fall was about ten feet. Another midshipman was in the next shrouds, but he was afraid to jump, and he went down with the ship."

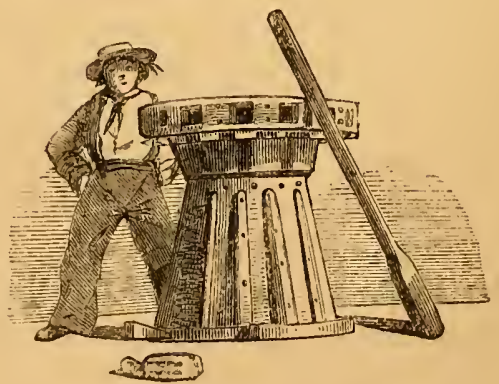




\section{CHAPTER VIII.}

THE ANCHOR WTTIIS THE VEIL.

WHY was it, it is time to ask, that there was not a greater clamouring after escape, both among passengers and crew? Why was it, that when all on board knew that the ship was doorned, and that at any moment the deep might open to swallow them up, there was not that wild delirium and agony of despair which we have been aceustomed to see associated with such considerations? To understand this in some measure, we must take a glance at what had transpired in the saloon of the ressel from the commencement of the voyage.

The saloon of the London had been constructed with the strictest regard to the confort of her first-class passengers; nor had their tastes been disregarded if they had any admiration of what was elegant and chaste in workmanship. Here there would be throughout the voyage a common meeting ground for members of the same class amongst ladies and gentlemen; and here religious services would be conducted on the Sabbath, at which all on board might be present.

On the first Sunday out there was a religious service, and Dr. Woolley associated with $\mathrm{Mr}$. Draper in conducting it. Both these gentlemen were known to each other, and, although belonging to different sections of the church, had many friends in common, by some of whom, experieneed in similar voyages, the steamer in which they were to retum to Australia, and the cabins they had taken, were inspected and approved. From Mr. Draper's known characteristics it may be affirmed as a certainty, although as yet no record of it has reached us, that as, on their very first Sunday out, they encountered heavy 
weathor,-a strong wind having sprung up and a heavy sea,he would find matter for religious instruction applicable to their circumstances. And we cannot tell how largely the divine blessing may have accompanied the religious scrvices of the day. If it be true that before the barren fig-tree is cut down, the influences and means used to quicken it into life and fruitfulness are more than doubled, may we not say that He to whom all things were known, and who saw the end from the beginning, vouclisafed a more than ordinary blessing to the gospel declared to more than two hundred who were spending their last Sabbath on eartli?

On Monday, there being no abatement in the violence of the weather, but, on the contrary, the storm rather heightening in force, the ladies and passengers generally would keep their cabins, or meet for conversation in the saloon. On Monday we know that many on board felt more fear than they did on subsequent clays when the first shock of the tempest had worn away, and they had become accustomed to a hurricane that never changed but for the worse. There were, we know, several on board who had been professed Christians for years. There was one who had, we believe, two brothers in the ministry, and who was a spiritually-minded man himself. There was another who was the son of a very distinguished Minister of Christ, and who was himself a devoted Christian. There was a young woman who had just left service in Suffolk, and who had written a letter while on board to a Christian friend, which went to shew the reality of her religious life. There were many who were in the habit of reading their Bibles daily.

We mention these as types of the different classes composing the passengers, and as illustrative of the fact, that over the vessel there was spread a goodly number of per- 
sons who were not ashamed to own their Lord, and who, when they saw the clouds of distress gathering around their fellow-passengers, would be able, and, as we have heard, would be certain to be all the more earnest and useful and kind in proportion to the distress they saw exhibited. That during the fearful gale which sprung up on Monday night there would be distress and fear of the direst kind we make no doubt, but we gather comfort from the fact, that the example and exhortations of the godly would not be without their salutary and soothing influence.

Directly, we hear nothing of $\mathrm{Mr}$. Draper's exertions until Wednesday, from which time until the vessel went down he was incessant in his ministrations ; but, as we hear of groups of children looking up with wonderment into the frightened faces of their mothers, of ladies reading the Bible to each other, and of individual passengers turning over its leaves as if in search of passages that would be suitable to their condition, of husbands sustaining wives by their constant presence, -we may be sure that the man who was as loving to his fellows as he was faithful to his Master had already lost all thought of self in the work of imparting consolation and instruction in the awful circumstances in which those especially were placed who had now for the first time to begin to think seriously of the claims of religion.

"From all I have heard respecting him," writes the Hon. Mr. M'Arthur, "self seems to have been altogether lost sight of. Nor does it appear that he paid any special attention to his beloved wife, to whom he was most ardently and devotedly attached, but his whole heart and mind seem to have been engaged in the great work of endeavouring to lead those by whom he was surrounded to flee for refuge to the only hope set before them." Nor though we do not hear so much of $\mathrm{Dr}$. 
Woolley as we do of $\mathrm{Mr}$. Draper throughout the appalling calamity, are we therefore to suppose that he was untrue to lis sacred calling, and to the loving instincts of a very kindly heart. Had the facts of his life been before us, we should doubtless have been able to speak of him with as much length as we have of the Wesleyan preacher. One who evidently knew and loved him has said, "Not much is said about him; but we know in what manner he would die and help others to die. His public career may be told in other ways, but this one rord is in remembrance of the man himself-the good man-Joln Woolley."

On Wednesday, as we have said, the testimony concerning Mr. Draper's efforts, and the results attending them, is clear and decisive. Prayer and religious instruction had become general, and the saloon was transformed into a sanctuary, from whence ascended the voice of supplication and weeping to Him who was alone able to save. There were carnest wrestlings of soul amongst those who felt themselves face to face either with heaven or hell. It was hard to feel all at once that they must die, that there could be no escape. It was hard for the newlymarried of a week only to feel that all the joys and hopes of life must be ruthlessly terminated. It was hard for all who had formed their plans for the future, or who had just left in England those whom they held so dear, or who had brought their little children out with them intending to settle in a new home,-very liard for all to be told with a decisiveness which there was no gainsaying, that they must die. And no wonder that in the first burst of agony which this conviction brought with it, many gathered round the Minister, crying, "Pray with me, Mr. Draper. Pray for me, Mr. Draper."

And he did pray. Those who knew him have much to tell of his power in prayer, of it being the effectual and forvent 
supplication of a man, "who was as sure of answer as if voices from heaven told him he was heard." Happy indeed the man, who seeing deatl written in every face, and surrounded by the weeping and conscience-stricken, had no time and no disposition to care for himself, in the Christ-like work of caring for others. As he drew nearer to Heaven, he had yet deeper fellowship with the sufferings of that blessed Master he served, who, while hanging upon the cross, had leisure to think of all wants but His own. The Master saved others; Himself he could not save.

All Wednesday, as we have seen, the storm raged with incessant fury. The passengers below heard and felt with bated breath that tremendons sea break over the ressel by which the cutter was stove in and the starboard lifeboat carried away. The passengers in the saloon must have felt the shock in all its terrible might, for it broke against their quarter of the ship; and perhaps it was then, when all expected that they were going down, that Mr. Draper was heard praying, "O God, may those that are not converted be converted now-hundreds of them." This prayer went up again and again during that stormy day.

Again there was a crash overhead, and those below heard to their dismay that the main hatchway had been swept away. There was the rushing of water heard pouring down into the engine room; there was the Captain's voice heard shouting through the storm, and the responsive cry of the crew. "Prepare to meet your God. Prepare to meet your God!" This was the solemn admonition of the minister throughout the day and night.

At twelve o'clock that night there was a prayer-meeting in the saloon, which was attended by all who could be spared from their duties on deck. A marvellous meeting indeed it 
must have been, in which strong cries and tears went up to Him whose word was pledged that He would not turn away his ear from the roice of prayer; that Ho would listen to the cry of the afticted.

And did He not listen? Did Ho not answer? We would humbly hope that the prayers presented were not the off'spring of mere natural terror, but the utterances of broken and contrite spirits. On Thursday morning a wondrous calmness had taken possession of all hearts. There were no agonizing shrieks and screams, no delirious efforts to escape from their doom. The prayer-meeting, and the prayers of the last three days had done their work. Something stronger and holier than love of mere natural life had taken possession of many liearts. Their's was the victory which had overcome death, even their faith. Not even when the Captain entered the saloon, and sadly amounced that there was no hope, did their calmness and resignation forsake them. "Let us pray," Mr. Draper said, and then they quictly prayed by themselves. Shortly afterwards the minister said with great kindliness, "Well, my friends, our Captain tells us there is no hope, but the Great Captain above tells us there is hope, and that we may all get safe to heaven." Blessed truth! we have no doubt that it went home to the hearts of many. Friends began to take leave of friends, as if preparing for a long journey. Husbands, wives, and children clung to each other as if death itself should never divide them. And, clinging to each other, and, we trust, to Christ, they calmly waited for the sea to swallow them up, amid all the excitement of launching the port cutter. 


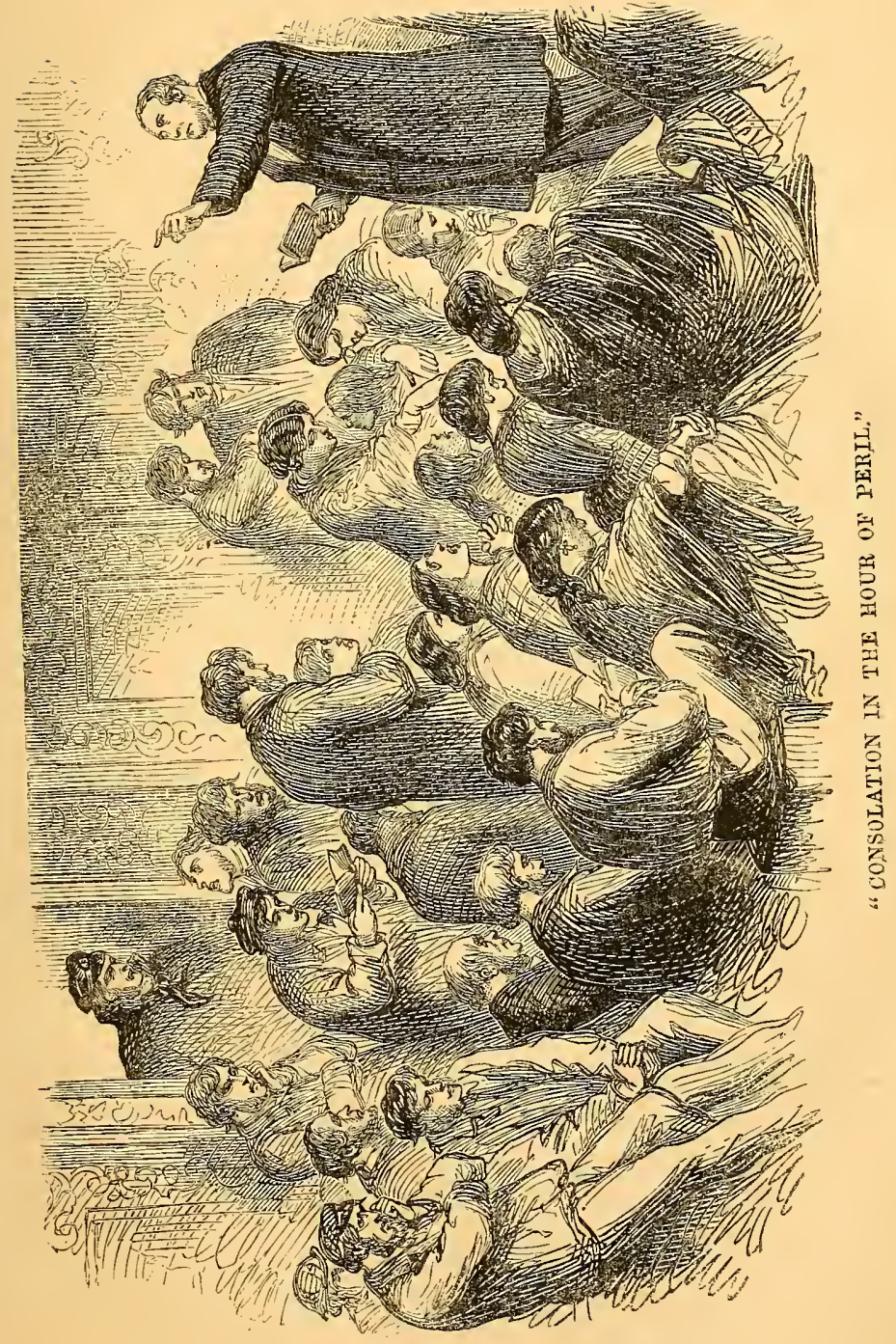





\section{CHAPTER IX.}

\section{LAST WORDS.}

AT last, but with greater precantion than before, the port cutter was launched, and got safely down. Six men were in her, but as she rose and fell with the fury of the waves, and every moment appeared likely to swamp, all felt the propriety of the Captain's words, that in such a sea there was but little chance for the boat. The command of the boat belonged to Mr. Greenhill, as second engineer, and without loss of time he was anxious that all who had determined to make one more desperate struggle for life should hasten from the poor doomed ship. She was fast settling down to the water's edge; there was a fearful swirl of water around her stern, and the cutter was in danger of being sucked down into the whirlpool of the wreck. It was a leap for life in the case of each one who jumped from the vessel, for the cutter seemed no more than a piece of cork upon the tumultuous billows, and no wonder that many paused and drew back in horror from a leap to what seemed nothing short of instant death.

It was while the ship was fast filling with water, and death every moment drew nearer, that some last words were spoken that will never be forgotten by the survivors, or by those to whom, in some instances, they were sent. What were $\mathrm{Mr}$. Draper's last words? He had been exhorting and praying, without intermission, for more than twelve hours before the ship went down. Two of the survivors have a distinct remembrance of him as they last saw him, about an hour before the boat left. He was then in the saloon, and men and women 
were still gathering around him, and saying, "O ! Mr. Draper, pray for me!" The last words these two survivors heard him utter were these: "Well, my friends, our Captain tells us there is no hope, but the Great Captain above tells us there is hope that we may all get safe to heaven."

Another saw him a few minutes before the boat pushed off, and his testimony is that Mr. Draper was then heard exclaiming, "Prepare to meet your God." The devoted minister was calm and self-possessed, although the corpses of women and children were floating over the deck. His wife was with him: hand in hand they would go down together into the deep, and together enter into the Father's rest, in a very few moments now. Patience a little longer. Mrs. Draper was a sharer in her husband's faith, calmness, and heroism; a noble co-operator with him in all sweet deeds of self-sacrifice. It moves one to tears to hear of her thoughtful care for others in that last dread moment. A short time before the boat had left the vessel she handed her rug to some of the sailor's to help to keep them warm. "But what will you do without it?" "It will only be for a few minutes longer," is said to have been her reply. There was, in this last act of hers, the simple, quiet expression of what her life had been for many years - a life of inobtrusive effort for the good of others. In the hour of awful peril, when it would have only been womanly and natural for her to have claimed her husband's care and solicitude, we do not hear of her, for a single moment, interrupting him in his sacred task. She herself, doubtless, did what she could to help him in the work of imparting spiritual instruction to those who were every moment expecting death.

When Mr. Draper was last seen, and that was a few minutes before the boat was cut away from the sinking ship, 
he was heard speaking with deep emotion, but with the clear strong voice which naturally belonged to the cheerful-hearted man-and that he was right through life-saying these words: "Those of you who are not converted, now is the time; not a moment to be lost, for in a few minutes we shall all be in the presence of our Judge." And again the word sounded, "Prepare to meet your God." These were the last words that he was heard to speak by any who escaped, but doubtless, during the few minutes of life that yet remained, he continued to comfort and exhort; and not, perhaps, until the cold waters closed around him, did he give himself leisure to pray for himself, perhaps saying, "Father, into thy hands I commend my spirit."

Peace be to his sweet and precious memory! Although no monument marks the spot in the vast cemetery of the deep where his ashes repose, the place of his sepulture is well known to Him by whose mysterious hand he was buried, and in the appointed hour the sea shall give up its dead, and he shall be found in his place at the end of the days. Death to him had not come untimely. Thousands will bewail his loss, because it is theirs, not his. For him to die was exceeding gain. He had less of earth only to have more of heaven. Through the tempest and the flood he found an earlier passage to immortality than his love of labour in the Master's vineyard allowed him to anticipate; but it is all well, because ordained by Him whose way is in the sea, whose path is in the great waters, and whose footsteps are not known.

There were other last words spoken while the little boat was being held to the ship's side with all the energy of despair. Mr. Munro, a passenger, had made up his mind to try the faint chance of escape which entering the cutter afforded. All felt that escape was next to impossible, 
and Mr. Munro among the rest. Before leaving the vessel, however, he went down to the cabin where were some friends of his from Ballarat, Mr. and Mrs. Hickman and their young family. It was a terrible task even to make the proposition that he had come to make known: it was that there was room in the boat for one! It was impossible that the poor children could escape; not one of them could be expected to take the fearful leap required; nor could Mrs. Hickman; but her husband,- -he conld escape, perhaps, if he would, and if the boat did live out the fearful sea, he might be saved. Mr. Munro urged his friend to avail himself of the chance.

But no! Mr. Hickman had no need to look at his wife and four little ones, around whom the water was rapidly rising higher and ligher, ere he gave the answer. The water was then a considerable depth in the saloon on the lee side, as the fond husband and tender father replied to his friend's entreaty thus:- "No! I promised my wife and children to stay by them, and I will do so!" Brave determination, one never to be regretted by him who made it, never to be forgotten while tales of heroism have any power left in them to move human hearts to enthusiasm and tears. His choice, though a melancholy, was the right one, and his friend acted kindly in not further attempting to divert lim from it.

"Help me," said Mr. Hickman, "to move the children to the other side, out of the water."

Mr. Munro performed this last act of kindness for his friends : they then shook hands. The last words of that fond father were, "Good bye, Jack!"

His friend then left him for ever. But will he erer lose,-alas! alas! will any one who reads the story erer 
lose sight of the vision of that loving father and mother, with their four children, standing in a row to the windward side of the saloon, and thus momentarily expecting death !

Peace, poor weeping motlier and devoted father! Peace, ye dear helpless children! There is One on high whose voice of love is mightier than the voice of many waters, and we humbly hope that those parents, with many others in a similar position of peril, passed through the sharpness of death into His presence, who would smile upon them a welcome, the first glance of which would for ever banish the remembrance of pain, as they cried, "Behold us, and the children thou hast given us!"

But there were more last words yet. Upon seeing $\mathrm{Mr}$. Munro return alone, the men in the boat shonted to him, "There is still room: fetch a lady!" Hearing this, he sprang" across a portion of the deck in quest of a lady whom he knew; but not seeing her, and knowing that the moments were flying fast, he said to a young girl, "Will you go?" She appeared willing to do so, and Mr. Munro immediately caught her in his arms, and hurried with her to the bulwarks; but when she looked over and saw the distance she had to leap, she said, in an agony of despair, " Oh, I cannot do that!"

The boat seemed every moment as if it would go down amid the terrific roll of the sea, and she drew back in affright from the awful gulf that appeared yawning to receive her. Mr. Munro was obliged to drop his hapless burden, and to leave the young creature on the deck, while he himself leaped from the bulwarks into the rolling boat below.

There was one young man on board, in whose spiritual welfare a clergyman in the suburbs of London had taken deep interest before he embarked on his fatal voyage. The youncr man had remained undecided for Christ, notwithstanding all 
entreaties and appeals; but ere he went on board the London his friend the clergyman liad implored him to offer up daily a prayer which he had given him. Neither, perhaps, could hare possibly dreamed of the circumstances of peril under which that prayer would come to be used. There came now some last words from that young man. Amid the raging of the storm, he shouted out to one who was in the boat-" If ever" you get safe to land, tell Mr. - - (mentioning the clergyman's name) that the prayer he gave me I lave used every day since; and that now I can say of Christ, "My Beloved is minc, and I am His." "These were his last words; but how much happier-brief though they were-liave they made many a Christian heart, telling, as we humbly hope they do, that the speaker had escaped the second death, and that the haven of eternal rest was in sight.

There was a young girl on board whose last words were not spoken, but written. Was she the one of whom we read as standing bareheaded in the wild storm, with holy resignation depicted in every feature? She hurriedly wrote a few words on a slip of paper, and said to one who was about to leap into the boat, "Give this to my mother." Her last wish was sacredly obeyed, and there came to a mourning mother this serene message from one who had gone down in a stormy sea- "Dear mother, you must not grieve for me: I am going to Jesus."

Miss Brooker, of Pimlico, spoke her last words, and they were those of quiet resignation to the will of God. IVe hear of her, during those days and nights of fearful suspense, doing. what she could to soothe a fellow-passenger whose mind at times seemed on the very verge of delirium, the absence of which among the passengers generally, while it is matter of devoutest gratitude, is also matter of greatest wonder,-mnless explained by the presence of Him who walketh upon the 
wings of the wind, and who, in answer to prayer, was shedding abroad in many hearts a tranquillity so deep and hallowed as to be beyond the reach of the wildest tempest. As the end drew rapidly near, Miss Brooker clasped her hands, and was heard to say, as if to herself,-but, oh! there was One by that heard all that was said during that awful last hour,"Well, I have done all that I could ; I can do no more!"

Nothing now, except trust, and hope for the life beyond this troubled one. Nothing now, but to make the most of those exhortations which, with trumpet-clearness, rise every now and then above the howling of the gale- "There is hope that we may ALL get safe to heaven. Those of you who are not converted, now is the time: not a moment to be lost, for in a few minutes we shall all be in the presence of our Judge."

There were more last words still, and they were those of Mr. G. V. Brooke. Only a few days before,- on the 23rd of December, - he had sustained the character of Richard the Third. The walls were not placarded with the announcement, "The last appearance of Mr. G. V. Brooke upon any stage," but they might have been so; and how would the hundreds who listened to lis farewell address that night liave felt, could they have caught the double meaning which the opening sentences of that address contained, at least as we read it now?

The actor was in painful ill-health, and his subsequent heroism on board the foundering London derives additional interest from the fact. His last words at Belfast were these:"Ladies and Gentlemen, with this night finishes my professional carcer in Belfast for a long, very long time to come. I fervently trust, by the favour of the One Providence, that I may at some distant time be enabled to return to a town which I, in a measture, look on as my home, where I may professionally 
or umprofessionally, mingle with my friends in Belfast again. I now take an affectionate farewell of you all, wishing fiom $\mathrm{my}$ heart continued prosperity to this magnificent city."

These were his last words on any stage. A few days later, and he was bearing his part in no mimic tragedy, -in a conflict which, in its way, was far more appalling than the battle of Bosworth Field in which Richard fell. As we watch the closing scene of the poor actor's life, one cannot have a heart and remain unmoved or silent in the presence of the man who, in weak health and with painful hoarseness, did the work of many men combined during those despairing days. Did the hundreds who listened to him in Belfast catch any prophetic hint in the mimic agony with which he delivered the death speech of Richard?

\section{" I have set my life upon a cast,}

And 1 will stand the hazard of the die !

The time had come, when, in reality, there was no earthlymeans of escape, and, seeing that all his exertions were useless, he rested upon one of the half-doors of the companion, and, bareheaded to the storm, gave himself up to reflection. His last words to man were to the steward, "If you succeed in saving yourself, give my farewell to the people of Melbourne ;" but who shall say what words were addressed to Him who was alone able to deliver, during those four hours in which he was observed to contimue in a musing attitude.

Strangely enough, there were last words spoken, which, upon being repeated by the survivor to whom they were addressed, will doubtless carry a ralue which, had the speaker known, would much have soothed him during his closing hours of life. A son was on board the London, who, with death staring him in the face, thought tenderly of the old 
man his father, whose declining years would have been rendered all the happier for possessing money that must now, as the speaker thought, sink with him, and be lost. Among the second cabin passengers were two, Mr. Munro and Mr. Eastwood, who had been acquainted previons to the voyage. As the little boat was being filled with all it could hold, Eastwood, addressing his fellow-passenger, said, "Well, Jack, I think we are going to go." "I think we are, Eastwood." "Well, we camnot help it," the other went on. "There's only one thing I regret about it: of a draft for 500l. on the Bank of Victoria, Ballarat, I only received 20l., which I gave to the Captain, in the office of Money Wigram and Co. I should have liked my poor father to have got the balance." These were the last words of a son, who soon after perislied in the waves, but his friend escaped, remembering exactly the words which filial tenderness had inspired.

There were some last words spoken which we cannot record, words of the sufferers to each other, and words addressed to Him whose ear is never heavy to the cry of distress. Husbands and wives, parents and children, friends and acquaintances,-what words of farewell passed amongst these! What last words of prayer mingled even with the sighs of death! With what tender compassion and sympathy have those been thonght of whose heroic actions on board the doomed ship were the last words that will be sacredly cherished in the loving memory of those who knew them. The picture of that brave young officer, Mr. Angell, standing to his post to the last at the donkey-engine, which was used in working the pumps, calmly keeping there while the billows thundered their spray around him, and going down into the dark whirling water with his hands still on the engine; - this is a picture which no artist, however gifted, can paint strong and beantiful enough 
for us. It was his last sermon-and how eloquent was itto all the young officers of cur Navy upon a sense of duty, making him who possesses it superior to all thoughts of dang er.

There was something, too, inexpressibly touching in the incident of that aged couple who had three children with them, who had been wrecked already twice in their attempting to get to Melbourne, now being on board the sinking ship, and being swept overboard before the final hour came. Among the passengers, also, we read of two stout old people who had become favourites on board, and who had been sent for by an only son. The son will expect them at Melbourne: alas! how many will be expected there who will never aruive thither. One's heart quivers in anticipation of the sorrow into which multitudes will be plunged. When the poor aged couple knew that there was no chance of escape, they simply took each other by the hand, and went down into the cabin to die together.

But come there no last words from the gallant Captain, who, since Sunday, has had no sleep, and who has not even changed his clothes? Where is he while farewells are being exchanged, while the little boat is being filled with all it can hold, and while his beautiful vessel, which once seemed to walk the waters like a thing of life, is so fast filling, that her bulwarks nearly touch the water?

We catch glimpses of him several times while the boat is being lowered, and while it is being filled with sixteen of the crew and three passengers, and at all times we see him at the post of duty, and doing his best. About an hour, perhaps, before the getting away of the boat from the ship, Mr. Jones, the chief engineer, was between decks near the engine-room. The ship was then labouring in the trough of the sea, and was in a most disabled condition. He ran up between decks, and 
met Captain Martin for the last time, who was going in the direction of the saloon.

"Well, Mr. Jones, how do you feel?" was his question.

"Not well, Sir," was the reply: "I took it that he referred to my condition of mind and not to the accident I had met with. I saw no more of him after that. I saw nothing but the ship going down after that. When I left the ship the passengers had given up all hope, but there was a remarkable composure amongst them, and no loud'sounds to be heard. I heard voices engaged in preaching and praying."

Mr. Jones was the last man who leaped into the boat: he leaped and got into her as she rose with the sea, and the sea rose so high that he had scarcely any distance to jump from the gunwale. Before, however, the first engineer leaped into the boat it had already been gradually and carefully filled, as we have seen, with members of the crew and with three passengers. Mr. Greenhill, the second engineer, was supposed, from his position, to be officer of the cutter, and he took command of her. "Get in to the boat," the Captain had said among his last words; "there is not much chance for the boat; there is none for the ship. Your duty is done; mine is to remain here. Get in and take command of the few it will hold." His command had been obeyed, and now the only chance for the nineteen in the boat was to get as quickly away from the ship as possible, for the ship was being washed over to the boat, and she was in great danger of being sucked down, as we have said, with the sinking vessel. Before pushing off, the men in the boat shouted to the Captain to join them.

"No," he replied; "I will go down with the passengers. Your course is E.N.E. to Brest, and "-throwing them a compass"I wish you God speed, and safe to land."

These were the last words the survivors heard fall from tho 
lips of John Bohun Martin; but at that moment there came a fearful last word from the deck of the sinking vessel. $\Lambda$ lady, with horror on every feature, shrieked out most piteonsly, "A thousand guineas if you will take me in."

But if she liad offered the whole world there could have been no response to her cry. The boat, which had been hastily cut away, was already some yards distant, and to return would have been certain death to all, who, as it was, had not in their own minds the slightest hope of escaping. $\Lambda$ bout five minutes afterwards, and when they liad got eighty or nimety. yards, they looked towards the ship, and saw that she was going down stern foremost. The wind at this time was laging so violently that the men in the boat could not liear each other when eagerly slouting. It was with a lind of dumb wonderment that they saw what transpired. As the ship sunk it was seen that all on deck were driven forward, not by water, but by a tremendous and overpowering rush of air from below, which, as it escaped through the deck as well as the hatches, impelled all on deck forward with violence, and their dreadful struggle must have been, therefore, soon orer!

In a single moment the men in the boat secmed to take in at a glance all that transpired on board. They saw the stem of the vessel rise so high, that her keel was completely out of water as far as the foremast. The boatswain, the butcher, the baker, and the purser's mate, it is said, had resolved to attempt their escape in the remaining boat over the cuddy, which was already provisioned and launched; but no sooner were these men ready to put off, than the sinking vessel sank beneath them, making, in lier descent, a very whirlpool of angry and confounding waters, and the escaping ones in the cutter saw their comrades swallowed up 
quickly and disappear with the lost ship. They saw young Angell going down while standing at his old post of duty: for a moment they saw two men with life-belts struggling amid mountains of water: they rose with the waves, and then descended into the deep, deep grave which the sea formed for them, and then not a trace of men or of ship was to be seen: The gale thundered so furiously, that if there was a cry from the sinking ship, it was not heard. Once more to the bottom of the Bay of Biscay had gone a noble ship and valuable cargo; but $O$ ! saddest of all, more than two hundred forms, that a few days before had been seen sitting in mirth and friendliness around many an English fireside, had gone down too. And once more the billows rolled on, curling their monstrous heads, as if in contempt of the beings who would seek to master them when once they rose in their terrible might and majesty.

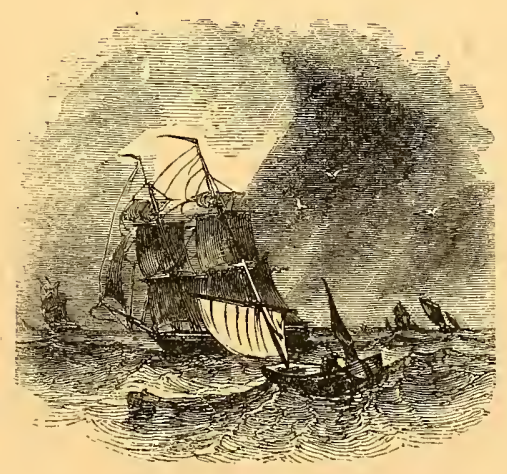




\section{CHAPTER X.}

THE LIGHT BEIIND THE CLOUD.

WAs there such a light? It was one of the saddest of calamities, desolating at a stroke many a bright home, and nipping in the bud some of the fondest hopes and purposes. Was there such a light? The disaster swept away two hundred and twenty lives, around which many other lives twined like the gentle tendrils of a vine, and who will, perhaps, wither now that the props to which they sweetly clung have been torn ruthlessly away.

Was there such a light? The aged and the young went down together into the same grave. The infant child of four months old was dashed far away from the sinking mother's breast, and heroism of the loftiest type received no higher reward than the dullest, basest cowardice.

Was there such a light? The refined scholar, for whom his pupils wait-the tencler father, for whom a widow and six children, with only slender means for their support, anxiously look out-the gently strong John Woolley has gone down into the deep, and the sea has taken no more account of his worth and power than it has of the fool.

Was there such a light? Captain Martin has gone; the man who fearlessly traversed the ocean for years, who had often smiled at danger, and had gone between Melbourne and London until the path was as clear to him as the turnpike-road to the waggoner. The gentle, courageous good man will never more be greeted by his relatives, and the wide circle of friends who loved him will see him no more.

Was there such a light? Daniel Draper is lost to the 
church and to his only son; his brethren in the ministry will no longer be able to depend upon his wise suggestions; and souls unnumbered are still white unto harvest, while the successful reaper suddenly drops his sickle, and will gather in no more sheaves.

Was there such a light? and in what quarter of the heavens did it glow behind the great darkness in which the good ship went down into the whirlpool of destruction with 220 lives on board?

There was such a light, and we have no doubt of its beaming over this dark catastrophe still,--the light which shines through the words,

\section{God IS LOve.}

That those who now most need the light of this truth to guide them will see even the faintest glimmering of it, we cannot say; but when the blindness occasioned by the smart of tears has cleared away, we are sure, that if they will look up there will be the truth mildly shining behind the calamity, dark though it be. The mystery, appalling though it be, can, in this world, receive no truer solution, but a lifetime may pass away without our even having learnt the letters by which the truth is to be slowly spelt out.

But while the mystery remains, the calamity loses much of its horror, if we lay to heart the truth of the over-ruling providence of God. "It is appointed unto man once to die," and the Omnipotent one has ordained the place, the time, the circumstances. Good and faithful servants were in the ship, and the summons that told them their way unto the Lord's presence was through the deep, brooked no delay; but the road was not half so strange to them as it seems to us. Before 
their cyes a light was shining which is hidden from our view, and by it they were conducted to their Father's house as serenely as if they had breathed their last on downy pillows. Down into the great deep they plunged, and then?

In a moment, in the twinkling of an eye, they liad left their sea-soaked raiment behind them, and they were at rest amid the blessed calm on which no tempest shall ever, ever, ever break. A rich feast was awaiting their arrival; bright and happy faces were around the board to welcome the guests who had come through the flood and tempest; and God Himself wiped away all tears from off all faces, and the voice of eternal love thrilled their hearts as it whispered, "There shall be no more cleath, neither sorrow nor crying, neither shall there be any more pain, for the former things are passed away."

Oh! could we think a little more of this scene beyond the flood, and less of the terrible shipwreck, we should assuredly catch glimpses of the light behind the cloud. From the eternal shore the voices of the faithful reach our world, saying, "Men of England, men of Melbourne, weep not for us, for we have all got safe to land; and the land is good, and, behold we were not told the half concerning it. See to it, that ye prepare to follow us in the way our Father sees best."

But through the sea? Yes, for the sea is his, and He made it; and God may use it as $\mathrm{He}$ did in the case before us, not as a minister of wrath, but of mercy, to conduct lis chosen ones to Himself.

But through all the agony which preceded the struggle, and through such a struggle?

Yes; if that too be the Divine will, for who was it that for our sakes chose the saddest and most lingering of deaths? and who, in the anguish of a fast breaking heart, cried, " $\mathrm{MI}$ God, my God, why hast Thou forsaken me!" 
But let us say that friends and relations are in danger of: making by far too much of the agony, and not enough of the. heavenly help that came to the shipwrecked ones, to enable them "to suffer and be strong."

We believe in the superiority of Divine grace to the mere. natural feeling of pain and anguish, and that when Divine. strength nerves the sonl, the keenest physical tortures are all outside things. The martyrs of old could without pretence woo the flames that consumed them, clothe themselves cheerfully as with a garment of fire; and while the chain around lim grew red hot, one could talk of his dying thus, as if he were on a bed of roses! And $\mathrm{He}$ who for some inscrutable but all-wise and loving purpose permitted the calamity of the shipwreck, may have thus supported his servants, and deprived them of agony as He had previonsly deprived them of fear-the greater agony of the two.

Is there not also a light behind the cloud, when the fact is called to mind how faithfully the gospel was preached, and how fervently most of those on board engaged in acts of devotion? There have been scenes of horror on board shipwrecked vessels which baftle all description, when it has been made known that the ship must go down. Then, shouts of cursing, despair, and drunken revelry have been heard above the fury of the gale, and mocked the very groans of the dying.

"Then rose from sea to sea the wild farewell,

Then shrieked the timid, and stood still the brave."

But on board the sinking London, amidst the storm, the gospel was preached, earnest prayers presented, the Bible read, and anxiety for the soul experienced. All as yet at least were in the place of hope on which the gospel ladder was 
planted, the top whereof touched heaven. They had not passed away to the region where faith would be impossible, and from whence there could be no escape. The way of salvation was simply pointed out to them again and again. They were not, we may be sure, burdened with details and theories, but the simple yet glorious truth was proclaimed, "Here is a Saviour waiting to save you, believe in Him and be saved. You are a simer, but He died for sinners; you are the very one He came to seek; trust yourself entirely to Hin; turn with a holy hatred and grief from your sins, and rely upon his promise to save you, if you only this moment, with all your heart, ask Him to do so."

And we may believe, and we ought to believe, that the gospel does not only offer immediate salvation, but that Christ does grant it to every man who penitently asks His help. The gospel preached during the storm was not, "Repent and believe the gospel, and you shall be sared at some future day;" the promise was, "You shall be saved now, and this day, though thy body may go to the bottom of the sea, thou shalt be with Christ in Paradise." Poor sinking one, only believe, and thou shalt see the glory of God.

There is light behind the cloud indeed, in the remembrance that such a gospel was proclaimed hour by hour; and in the conviction we also cherish that many believed it, gave themselves up to the influence of its promises and encouragements, and were so filled with faith in Him who had died to put away their sins and open the kingdom of heaven to them, that they were not afraid to die, seeing not death but heaven before them.

"Where all the ship's company meet,

Who sailed with the Saviour beneath ;

With shouting each other they greet, And triumph o'er trouble and death. 
The voyage of life's at an end,

The mortal affliction is past,

The age that in heaven they spend,

For ever and ever shall last."

"And so," doubtless it will be said, "you want to make them all religious, before the ship went down?" We would, indeed, kind reader, that we could cherish this hope concerning all, for then the light behind the clond would increase in brightness every day. As sinful men opposed to God we would have had all on board believers in the Great Reconciler, who can make both one, and fill the souls of those who trust Hin with the most blessed assurance that there is no longer any gulf of separation between them. Where there is this faith there is no fear, neither of dying, nor of what lies beyond death.

And, reader, in the hour that is before thee, as surely as it was before those that went down in the Bay of Biscay, it is only this faith in Christ that can impart courageous strength to thine own spirit, and solid consolation to the mourners who will presently bewail thee gone. If thou hast it, thou wilt go thy journey undismayed, while the heaven, to which thou art gone will shine brightly behind the cloud, and tell those who grieve thine absence most, that they need not sorrow as those who have no hope.

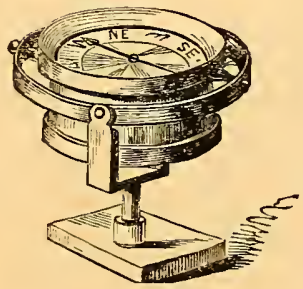




\title{
CHAPTER XI,
}

\author{
THE ESCAPE.
}

Nineteen persons had entered the port cutter. These consisted of the second and third engineers, one fireman, the boatswain's mate, the quartermaster, the carpenter's mate, the steward, the boatswain's boy, firc able seamen, and threc passengers. They had received their course from the now drowned Captain-N.N.E. to Brest, which was 190 miles distant, and they had compasses on board. Under the direction of King, the men agreed, that whatever might happen they would sit immoveable, except when pulling at the oars. Two worked at each oar, and they ran before the sea. Botl Daniell and King deserve the highest praise for their skill in steering the feeble craft over the raging waters, but it was. pleasant to find them both modest and seamanlike in all they said abont it.

"I believe you took charge of the boat, did n't you, Daniell ?"

" Well, I pulled an oar sometimes, and sometimes steered. I took no particular charge of the boat, but I gave my opinion and advice now and then."

"But you took a little of the lead?"

"Well, I did. Others also gave their opinion."

Among the "others" who gave counsel was Jolın King.

"How did you manage to steer?"

"Chiefly by the 'pointers' to the N.E."

It was a fearful struggle for life that the brave seamen now engaged in, as, with parched lips and every nerve strained to its highest pitch of tension, they rose and fell with the green 


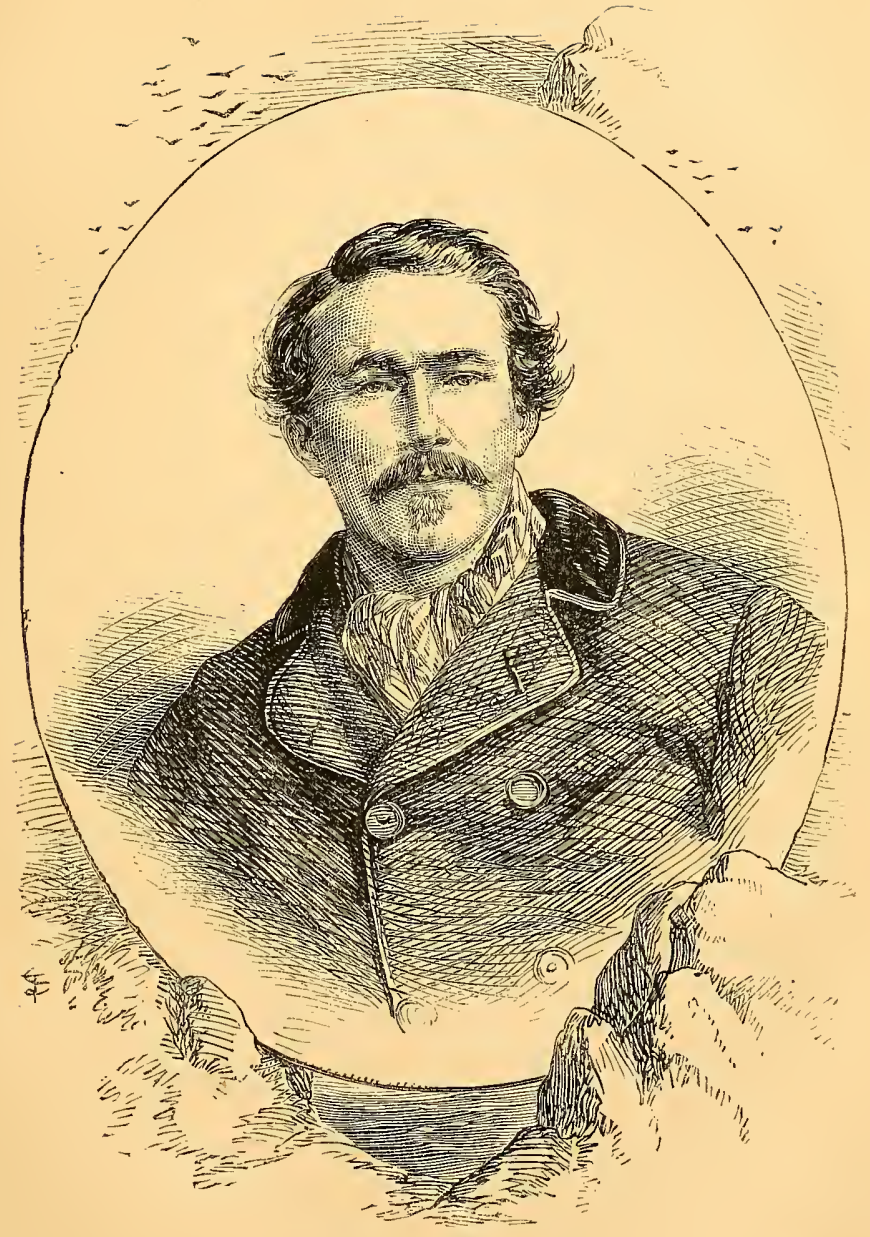

J $0 \mathrm{HN}$ KING. 

waves still running mountains high. It seemed almost hopeless to attempt to withstand any longer the fury of the sea, which broke over them in angry surges. As we have said, they had but a quart of water on board, and the bottles of spirits. It was a fortunate thing that young Edwards succeeded in getting hold of these and concealing them, for the probability is, that had the seamen given way to drink in their then excited state, raving delirium would have set in, and cutter and crew would soon have been at the bottom. The lad shall tell his own story, and he is worthy of lasting honour and remembrance for his part in it.

"Daniell agreed to be our hammock man. He sat by me and was pulling the bow-oar. There was a bag of biscuits weighing two cwt., two bottles of brandy, and two of champagne, some turnips and carrots, in the boat. There was some water also on board, but it was thrown out. I picked up three of the bottles and put them under my coat. Mr. Greenhill and Daniell knew I had them, but the others did not."

"Your conduct was very commendable," said Mr. Traill, "and you did quite right in trying to keep the bottles of spirit away from the men. You have begun your career unfortunately, but I hope you may hereafter succeed as you deserve to do."

Thursday night came on, and the boat still drifted before the wind, and about three o'clock the next morning a regular green sea broke over them and nearly half filled the boat. One of the passengers baled ont the water constantly, and after the green sea came in the water was baled out with a bucket and cans. Before daylight, and as the moon rose, the men saw a vessel close alongside. They hailed her with all their might, and were heard by those on board; but as they could present no light they could not be seen, although they 
could see the ship tacking about for an hour trying to find them. The search was fruitless, and to their utter disappointment the ship was lost sight of. The men adhered to their course, and about nine o'clock sighted two ressels, but could not get near them on account of the cross seas. They rowed for one of them, however, for nearly five lours, and upon getting within hail she proved to be an Italian barque, the Marianople. The boat was very near filling when they were within twenty yards of her. They were struck by a heavy squall, so that all in the boat gave themselves up for lost. In consequence of the excitement on board-who can wonder at it? - they did not succeed in clearing one of the seas; but by only one of the men moving in the boat to bale her out, they were enabled to bale her clear, and a log line being thrown them from the barque, one by one they were drawn up on deck! The young midshipman Edwards was drawn on board by men who caught him by the collar of his coat.

The shipwrecked were in a most benumbed and perishing state, but the mastcr of the barque, Captain Cavasa, treated them with the greatest kindness. The generous Italian could speak but little Englisl, but his deeds have spoken so forcibly that Englishmen will be long before they forget his kindheartedness. By his orders the men were stripped and rubbed, and clad in fresh warm garments. The good captain killed a turkey for them, besides providing tea and soup, and setting apart for them warm beds. After treating them with every kindness, he landed them at Falmouth, from which port the story of their marvellous escape, and the loss of so many precious lives in the London, flashed with the speed of the telegraph throughout the length and breadth of the land, producing everywhere grief and consternation unspeakable.

The following is the list of those sared:- 
John Greenhill, engineer; John Jones, second engineer; John Armour, third engineer; Thomas Brown, fireman; W. M. Edwards, midshipman; D. T. Smith, boatswain's mate; Wm. Daniell, quartermaster; John King, Benjamin Shield, Richard Lewis, James Gongh, Edwin Quin, William Grimes, seamen; A. G. White, boatswain's boy; William Hart, Carpenter's mate; Edward Gardner, second-class steward; D. G. Main, passenger; John Mumro, passenger; J. E. Wilson, passenger.

It is a remarkable fact, moreover, that the Iondon is the first ship belonging to the famous house of Money Wigram and Sons to which any serious casuality has occurred. In a century's experience, Messrs Wigram have enjoyed a perfect immunity from loss, with the single exception of the True Briton, which belonged to a former generation of the firm, and foundered early in the present century in the same fatal bay.

But in a ehapter treating of those who escaped from the wreck of the London, those must not be forgotten who narrowly escaped the doom which fell upon so many in the Bay of Biscay.

"Some hair-breadtl escapes in comnection with this disaster are well known. A lady who was desirous of proceeding from Plymonth with her family to Melbourne by the London, had made repeated pressing applications to the owner's agents at Plymouth, and the Captain had been consulted, but, fortunately for the applicant, had declared that his cabins were so full that he could not possibly accommodate her, a result that, at that time, caused her much disappointment. A second-class male passenger was so alarmed at the rough weather which the London encountered on her way down to Plymouth, that immediately on her arrival at that port he came ashore, 
resigned his passage, and went back to his home, thus unwittingly saving his life. A young man, as the result of some family quarrel, left his home, and took a passage by the London. He was advertised for, and importuned to return, his friends being unaware of his whereabouts. Messengers were sent down to Plymouth, and an influential ship's broker in the town was employed to intercept him should he attempt to sail thence. Fortunately he was detected amongst the passengers of the London, and his family communicated with by the broker, the result of which was that a brother of the young man came down to Plymouth, and persuaded the wouldbe emigrant to forego his voyage.

May those who escaped the voyage by the doomed vessel, as well as those who got safe to land from the wreck, feel the solemnity of that life which has thus been so marvellously rescued from a watery grare.

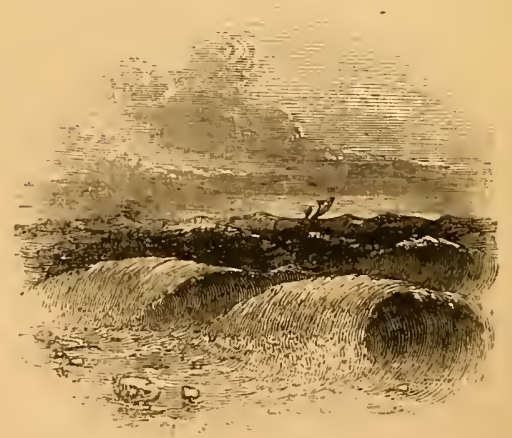




\section{CHAPTER XII.}

THINGS REMEMBERED IN THE STORM.

A NEw things were remembered in the storm, to which, when when we have called the reader's attention, our task is ended. The Bible was read in the storm. Donbtless the passengers had with them many books to relieve the tedium of a long royage, but good as these books might have been, it was not from these that they sought to derive instruction and comfort in the hour of peril. They opened their Bibles; many of them were seen in groups reading it together, or sitting by themselves turning over its pages, as if in search after some passage which had been forgotten, and the meaning of which was specially important then. They read the Bible during the most solemn hour of their existence, and when they knew that their moments were numbered, and whilst in the midst of a scene which its own pages have so magnificently described.

"They that go down to the sea in ships, that do business in the great waters; these see the works of the Lord, and His wonders in the deep. For he commandeth and raiseth the stormy wind, which lifteth up the waves thereof. They mount up to heaveri, they go down again to the depths; their soul is melted because of trouble. They reel to and fro, and stagger like a drunken man, and are at their wits' end. Then they cry unto the Lord in their trouble, and He bringeth them out of their distresses. He maketh the storm a calm, so that the waves thereof are still. Then are they glad because they be quiet; so $\mathrm{He}$ bringeth them unto their desired haven." 
That storm-tossed vessel, with her sinking passengers, has furnished no insignificant testimony to the preciousness of the Book which too many criticise as if it were the foe and not the friend of humanity. The picture of those passengers going down with their Bibles in their hands will be a sweeter one for the memory to treasure, than all the results of anatomical critics. And Oh surely! it will teach its lessons to those who are content to live in the neglect of, or in direct opposition to, the Book which in such an hour was appealed to, and not in vain.

Nor must it be forgotten that, on board the sinking London, the passengers attached the greatest possible importance to prayer. 'They prayed for themselves, and they besought an interest in the intercessions of others. During those wasting days and nights of lingering suspense they continued in prayer: it was their only comfort, and they went down into the deep with the voice of supplication upon their lips. Does not this teach its own solemn lesson to the prayerless who may read these pages? Does it not tell of a value in prayer beyond all the arguments that may be used against it, or even in favour of it? Those brave men and women, praying bareheaded to the storm, and going down into the wild waves calmly trusting in God's goodness still; - shall not this last touching act of theirs convey an appeal to the prayerless which there can be no resisting? Shall it not say in tones of entreaty that cammot be withstood, "Seek ye the Lord while He may be found, call ye upon Him while he is near?" Close to your heart with its deepest needs there stands a throne of mercy from which every imaginable good can be obtained : turn to that throne, be you in lane, highway, or open street, when this commandment reaches you, and seek salvation in the name of Christ, and you shall not seek in vair. 
Finally, on board the sinking London, the greatest attention was paid to a preached gospel. A preacher is not unfrequently heard enforcing his appeals to the undecided by the solemn words, "I speak as a dying man to dying men." In Mr. Draper's case the words were literally true, and they had all the pathos and hold of last words that might at any. moment be stopped by the overwhelming flood: and how the passengers listened! How important seemed every word then with either heaven or hell coming nearer and nearer with every inch of water rising in the engine-room !

$\mathrm{Ah}$ ! could those on land, and out of the reach, as they think, of such a calamity as shipwreck, but feel, that slowly yet, surely up to them is advancing the hour in which all earthly: interests will be as nothing, and the concerns of the soul all important, how would they now value the privilege of a preached gospel, and every instrumentality by which they can learn more of themselves and of spiritual things! A little while, and the last hour of every one who reads these lines will have come, and will be felt to be the last. How wilt thou meet it, reader?

It has been said, that in that last hour, no matter how aged the dying one, the memory awakes to its keenest power, and there passes before the mind a vivid diorama of all life's doings. Events and circumstances seemingly long buried, suddenly leap into life, and it well nigh startles one to listen to the remembrances that come and go through the fast-darkening chambers of the brain. Slowly dying on the pillow before us, lies one whose head is silent with age, and the grey dawn of an eternal morning is stealing over his features; but glancing brightly through the haze of death, there come to him visions of his long, long past; of the home of his childhood, of the bride of his youth, of the events of his riper age 
and manhood, until in a single hour he seems to live all his life over again.

Oh! it will be sad to remember, in such an hour, a neglected Bible, a throne of grace despised, and a gospel of mercy refused. It will be sad to remember, that even such a calamity as the wreck of the London produced no serious impression, and no turning of the head towards heaven. If the things which the sinking passengers remembered during the storm are remembered by you now,-if their deep importance is laid to heart by all whose feelings have been touched by the disaster,- - then, terrible though it has been, it will not have occurred in vain. It will have come in mercy to those who, in circumstances of fancied security, are not prepared to die. To such the voice of the sinking minister crying, even from the drowning wave, "Prepare to meet your God," will not have come in vain.

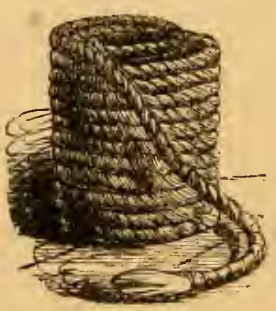




\section{APPENDIX.}

THE narrative which we have here given of the Wreck of the London was written pending the inquiry instituted by the Board of Trade to arrive, if possible, at the cause of the melancholy catastrophe. It is to be regretted that the inquiry, though it lasted many days, has not added much to the information that was given to the public by the survivors upon their landing at Plymouth. No discovery has been made as to the real cause which brought about the melancholy event, although it is hardly possible to conceive any question of more serious importance to the public mind. The evidence given at the inquiry was by no means satisfactory. On the one hand, those directly connected with the owners gave their evidence, and on the other hand, there was the testimony of the Emigration Inspectors who had passed the ship, and who could not be expected to stultify themselves by a new judgment of her seaworthiness. But against this testimony of shipbuilders and inspectors has been placed the evidence of those who declare that the ship was in disgracefully bad trim, and, as will be seen among the slips that were picked up in bottles that were cast away on the morning of the wreck, there was one which says that the vessel was too heavily laden. Great dissatisfaction has been expressed, and it has even been made a subject of discussion in the House of Commons, that Mr. Traill, the magistrate before whom the Board-of-Trade inquiry was conducted, did not permit Counsel to cross-examine witnesses on behalf of those who have lost relatives: but it seems that there really was no power under the Act of Parliament to 
admit of such cross-examination. The tonnage, measurement, and steam-power of the ship, together with the names of her owners, the nature and quantity of her cargo, were stated before the Court. We heard again the story of her voyage from the Docks to Gravesend, and from Gravesend to Plymouth, and from Plymouth to the Bay of Biscay. There was no charge made against Captain Martin, and no one dreamed of imputing negligence or incapacity to so experienced a seaman. The evidence of the official surveyors and other experts examined by the Court of Inquiry as to the construction and fittings of the London was, on the whole, decidedly in favour of her perfect seaworthiness. In the opinion of the Court, the immediate cause of her loss was the sea getting into the engine-room and extinguishing the fires; but the Court did not venture upon any positive conclusions as to whether the action of the sea carried away the skylight over the engine hatchway, or whether the skylight was properly secured. It did not appear in evidence that the fastenings of the skylight were not properly secured, and it was distinctly stated that the hatchway was perfectly battened down. There were several points in the evidence as regards the occurrences at sen-such as the carrying away the masts and booms, the delay in clearing away the wreck, the loss of the boats, and other matters relating to the management of the ship-which might have been more satisfactorily explained had the lamented Captain, or any of the officers of the ship, survived to explain them. In the absence of such explanation, it is but reasonable to give Captain Martin the credit for the character he always possessed, of being an able and careful seaman, who would not be guilty of any great default of management.

For onrselves, we can laardly believe that the ship was in the 
disgraceful condition that some represent her to have been, unless we are ready to assume that there was a gigantic conspiracy among all concerned in pronouncing the ship to be in safe trim. The Surveyor of the Board of Trade passed the ship; Lloyd's Surveyor, acting in the interests of the Underwriters, passed the ship; and lastly, the ship was passed by the Emigration Surveyor, who had not only to look to the ship generally, but to take into consideration her cargo, for the purpose of seeing whether she was overloaded. We join in the universal regret that the real cause of the ship's foundering, beyond what is given in the preceding pages, is still a mystery; and it only remains for us again to express the hope that still more scrutinizing care will be exercised by Government Inspectors and others, in regard to every ship concerning whose safe trim they are called upon fairly and honestly to testify.

Messis. Wigram have kindly forwarded the following List of Passengers per steam-ship London, Captain J. Bohun Martin, for Melbourne :-

\section{CHIEF CABIN.}

Rev. Mr. and Mrs. Draper

Mr. Owen and child

Mr. and Mrs. G. F. P. Urquhart

Mr. J. Patrick

Mr. and Miss Vaughan (Brooke)

Mr. J. Alderson

Mr. P. Benson

Mr. and Mrs. J. Fenton, and two children

Mr. G. M. Smith

Mr. and Mrs. Clapman, and two children

MIr, and Mrs. Clark, and son
Mr. F. Lewis

Mr. and Mrs. J. Bevan

Dr. J. Woolley

Mr. and Mrs. Debenham

Miss L. Maunder

Mr. J. Robertson

Mr. T. M. Tennant

Mrs. Traill and child

Mr. G. Palmer

Mr. T. Brown

Mr. and Mrs. Amos

Mr. E. Brooks

Mr. J. R. Richardson 
Rer. Mr. and Mrs. Kerr Mrs. and Miss King Mr. and Mrs. Thomas children

Mr. A. Sandilands

Mr. E. Youngman

Mr. H. J. Demnis

Mr. E. A. Marks

Mr. Kaye Eastwood Mr. F. Stone

Mr. and Mrs. White

Miss H. Price

Mr. J. L. Williams

Mr. and Mrs. Graham

Mr. B. G. Rowe

Mr. J. E. Wilson (saved)

Mrs. Morland

Miss G. Graham

Mr. J. Dothie

Mr. C. Gough

Mr. A. Bruce

Mr. J. Woodhouse

Mr. G. Cross

Mr. W. Day

Mr. D. W. Lemon

Mr. and Mrs. Giffett

Mr. G. Chennells

Mr. and Mrs. Wood

Master and Miss Clayson

and two $\mid \begin{aligned} & \text { Mr. D. F. De Pass } \\ & \text { Master W. D. Burrell } \\ & \text { Dr. J. Hunter } \\ & \text { Miss D'Ovoy } \\ & \text { Miss C. McLachlan } \\ & \text { Miss Cutting } \\ & \text { Mr. M'Millan }\end{aligned}$

SECOND CABIN.

Mr. Thomas Wood

Mr. Godfrey Wood

Miss E. Wood

Mr. B. Bevan

Miss S. Brooker

Mr. Davies

Mr. T. O'Hagen

Mr. H. W. Harding

Mr. F. Fryer

Mr. J. Mumro (saved)

Mr. D. C. Main (saved)

Mr. C. Johnstone

Mr. P. Fenwick

Mrs and Miss Meggs

Mr. G. H. Campbell

Miss E. Marks

Mr. E. G. Trevenen

Mr. and Mrs. Hickman, two sons and two daughter's

Mr. A. M'Lean

Mr. Davies

\section{THIRD CABIN.}

Mr. W. Passmore

Mr. H. Miller

Mr. C. P. Chandler

Mr. B. Hay

Miss E. Jones
Mrs. and Miss Simpson

Mr. and Mrs. Hanson

Mr. and Mrs. Graham and three children

Mr. David Graham 
Mr. McVittie

Mr. G. Rolwegan

Mr. and Mrs. Sercombe and three children

Mr. and Mrs. G. Flick and four children

Mr. R. Trevenen

Mr. D. Block

Mr. J. Gerkem

Messrs. Zulec Morris and Zulec Barnett

Mr. S. Bolton

Mr. T. Skeggs

Mr. and Mrs. D. Smith
Mr. A. Umphray

Master Spring

Mr. A. Hoyeim

Mr. J. Walls

Mr. W. Barron

Mrs. Lampes and two children

Mr. Algernon L. Otter

Mr. John Little

Mr. H. M'Covey

Mrs. Bachelor

Mr. J. Kirkwood

Mr. W. Clifton

Mr. R. Reynolds

\section{SEA MESSAGES FROM THE PASSENGERS.}

Admiral Halsted, the Secretary of Lloyd's, has received the following letter from Sir Anthony Perrier, C.B., Her Majesty's Consul, and Lloyd's Agent at Brest, dated 24th February 1866 :-

SIR,-I annex a translation of an extract from a letter just received from the Commissary-General of Marine at Lorient, which may be of interest to those concerned in the fate of the unfortunate London, should the original papers sent to Paris not have been transmitted to. Her Majesty's Government by the Minister of Marine.

I am, Sir, your obedient servant,

To the Secretary at Lloyd's.

Anthony Perrier.

Extract of a letter from Commissary-General of Marine at Lorient :-

(Translation.)-On the 12th of February last three bottles were found on the coast of Guiberon and Locruariaquer, containing six papers written in English, as follows :-

The first paper - D. W. Lemon, London, Thursday, 10th Jammary 
1866. The ship is sinking; no hope of being sared. Dear parents, may God bless you, as also me, with the hope of eternal salvation.

Second paper.-Steam-ship London.-They are putting out the boats.

Third paper:-F. G. Huckstepp. On board steam-ship London, lat. 46 deg. 20 min., long., 7 deg. 30 min. ; lost boats, masts, and sails ; ship leaking.

Fourth paper. - We commenced our voyage on Saturday, the 30th December 1865. Sunday in the channel, Monday in open sea ; Tuesday in ditto; Wednesday at Cowes; Thursday at Plymouth ; Friday and Saturdiry at sea; Sunday bad weather; Monday water from the stern comes in cabins; the 9 th, heavy clamages, a boat lost. May we get home. Storm.-H. G.

Fifth paper.-F. C. M'Millan, of Launceston, Tasmania, 12th January, to his dear wife and dear children: May God bless you all. Farewell for this world. Juost in the steam-ship London, bound for Melbourne.

Sixth paper.-H. J. D. Denis to Th. Denis Knight, at Great She?ford : Adieu father, brothers, and my .... Edi .... steamer, London, Bay of Biscay, Thursday, ten o'clock. Ship too heavily laden for its size, and too crank; windows stove iu; water coming in everywhere. God bless my poor orphans. Request to send this, if found, to Great Shelford. Storm not too violent for a ship in good condition.

On the same day were found, on the shoals of Guiberon, a binmacle watch, stopped at half-past ten o'clock, a woman's shift, two cotton sheets, two splinters of wood, having on them in white letters, and six centimetres ( $2 \frac{1}{2}$ inches long), the word London.

A great quantity of staves have been picked up along the coast.

In compliance with instructions from the Minister of Marine, the above-mentioned papers have been sent to the Minister of Marine and Colonies. 
INTERNATIONAL EXHIBITION, $\mathbf{x} 862$.

Award.-S. W. PARTRIDGE, Clafs XXVIII., Section C., Honourable Mention for Iliustrated Books

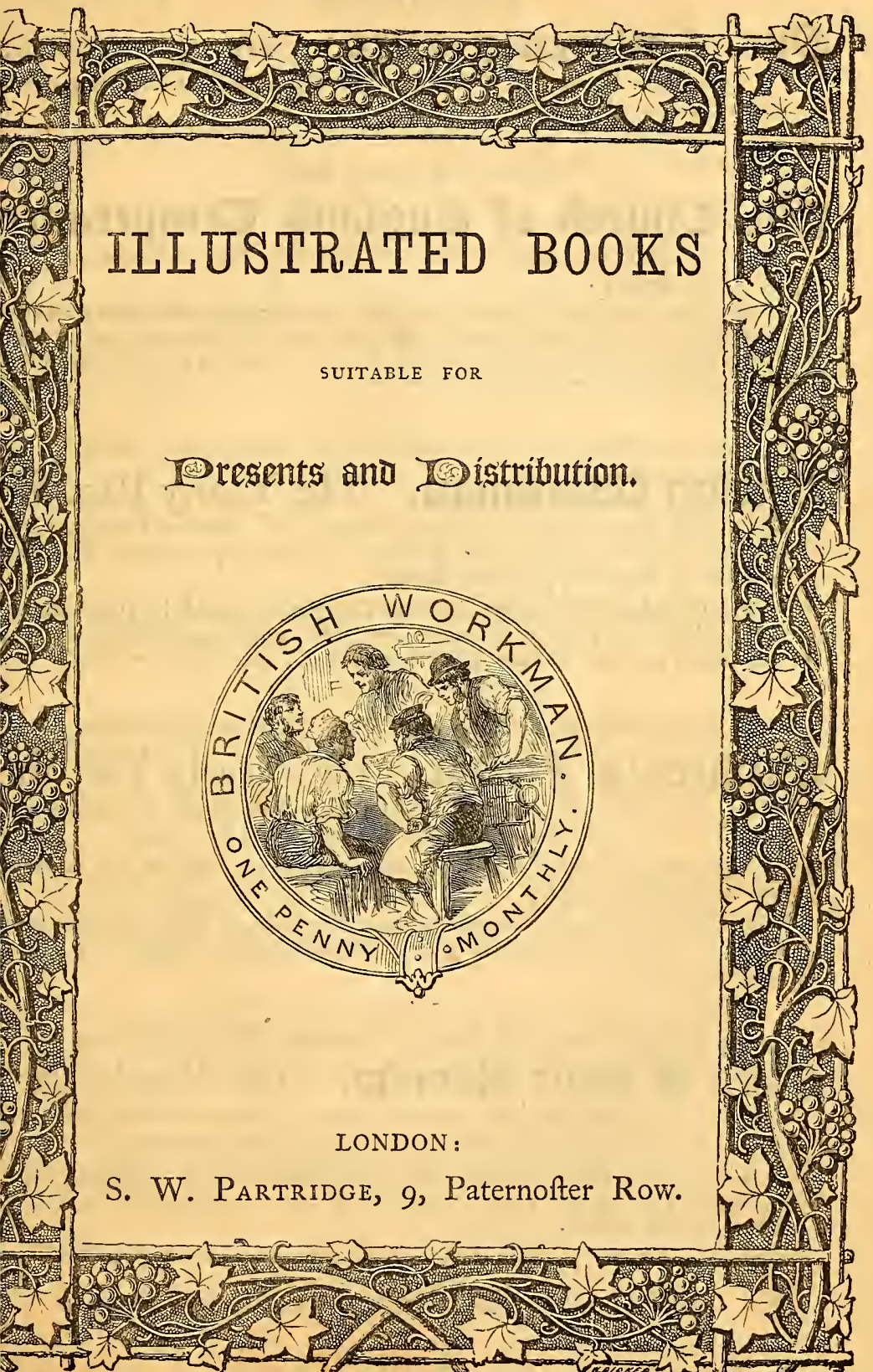




\section{Our Chíloren's 㹱et5. By Josephine. A Companion Volume to "Our Dumb Companions." Cloth, 5s.; cloth, gilt edges, 7 s. 6d.}

Illuftrated by various Artils.

\section{The Church of England Temperance} MAGAZINE. Publifhed in Monthly Numbers, price Threepence. Vol. for 1865 , cloth, 45 .

"It feeks to be of real ufe in winning men from the tap-room to the church; we view this movement as an effort, not fo much to fectarianife total abfinence, as to do the work which every church fhould labour more earneftly for, viz., the eternal, as well as the prefent falvation of the drunkard."-Cumberland Advertifer.

Full-page Pictures, by John Gilbert, R. Barnes, and Others.

\section{3 ritish Oatorkman. The Yearly Part for}

$\mathbf{8 6 5}$, with cover printed in colours, price is. 6d. Parlour Edition, cloth, gilt edges, 2s. 6d. All the Yearly Parts are always kept on fale. Publifhed in Monthly Numbers, price One Penny.

The Complete Edition for the first Ten Years, bound in One volume, cloth, plain, 15s.; cloth, gilt edges, 17s. 6d. 1855-59, cloth, plain, 9s.; gilt edges, 1os. 6d. 1860-64, cloth, plain, 9s.; gilt edges, ros. 6d.

Full-paged Pictures, by Harrison WeIR, W. Hunt, and others.

\section{Children's jprtend. The Yearly Vol. for} 1865, with cover printed in colours, 1s. 6d.; cioth, plain, 2s.; cloth, gilt edges, 2s. 6d. Publifhed in Monthly Numbers, price One Penny.

The previous volumes-1861 to 1864 -are always kept on fale, in three forts of binding, as above.

The Years 1861-64, Containing 1,000 Engravings, with many hundred pages of Letterprefs, bound in One handfome volume. Cloth, 6 ; cloth, gilt edges, $7 \mathrm{~s}$. $6 \mathrm{~d}$.

Full-paged Pictures, by R. Barnes, Harrison WeIr, and others.

\section{Lisand of}

for 1865 , with cover printed in colours, price is. Parlour Edition, cloth, gilt edges, 2s. Publifhed in Monthly Numbers, price One Halfpenny.

The FIRST SERIES may be had, neatly bound in One volume, cloth, plain, ros.; cloth, gilt edges, I2S. The SECOND SERIES (186r to I865), bound in One volume.

All the Yearly Parts from the commencement are always kept on fale.

London: S. W. PARTRIDGE, 9, Paternofter Row. 


\section{RONALD'S REASON; or, the Little}

Cripple. A Book for Boys. By Mrs. S. C. HALL. With TEN Engravings, Is. One of "The Children's Friend" Series.

\section{SYBIL ซ HER LIVE SNOWBALL.}

By the Author of "Dick and his Donkey." A Book for Girls. With

TWELve Engravings, is. One of "The Children's Friend" Series.

\section{TALK WITH THE LITTLE ONES.}

A Book for Boys and Girls. By the Author of "Rhymes Worth Remembering." With THIRTY Engravings, rs. One of "The Children's Friend" Series.

ROGER MILLER; or, Heroifm in Humble. Life. By the Rev. Geo. Orme. With an Engraving, cloth, is. 6d. [New Edition.

\section{PETER BEDFORD, the Spitalfields Philan- thropif. By William Tallack: With Portrait, cloth, 2s. 6d.}

\section{ILLUSTRATED PENNY READINGS:}

being Twelve feparate Readings by various Authors. Bound in cloth, is. 6d.; in packets' or paper covers, is. each.

THE FOUR PILLARS OF TEMPERANCE. By J. W. Kirton, Author of "Buy your own Cherries." With an Engraving, cloth, is. 6d.

THE BREWER'S FAMILY; or, Experiences of Charles Crawford. By Mrs. ELLIs. With EIGHT Engravings, cloth, 2s. 6d.

\section{MARIE $\mathscr{T}$ THE SEVEN CHILDREN.}

A Tale for Elder Girls. By Mrs. Geldart. With Ten Engravings, cloth, Is.

London: S. W PARTRIDGE, 9, Paternofter Row. 


\section{Story of Two Apprentices:}

The Difhoneft and The Succefsful. By the Rev. J. T. BARr. With Four Engravings, 6d.

"The 'Two Apprentices' thould be put into every boy's hands; they will be fure to read it, and cannot fail of learning fome valuable leffons from its pages. It is more natural and true than Hogarth's Two Apprentices." -Wefeyan Times.

[Tenth Thoufand.

\section{Hannah Twift :}

A Story about Temper. By Mifs BAKEweld. With Two Engravings, 6d.

"Hannah Twift is a young fervant girl unfortunately pofeffing a bad temper, which gets her into all kirds of difficulties, even from childhood; and ultimately is the fecondary caufe of her being apprehended on the charge of murdering the aunt of her miftrefs, for which the is tried and found guilty, and fentenced to die."-Art Fournal.

\section{Philip Markham's Two Leffons.}

By Author of "Dick and his Donkey." With Four Engravings, 6d.

$\because$ " Philip Markham is the title of an interefting ftory of one who was wilful and proud. Like Solomon's 'foolin son,' he was more than once a 'heavinefs to his mother.' But he learnt obedience through fuffering. His two leffons were dearly bought, but in the end worth more than they coft."-Glafgozu Cbrifian Nerus.

\section{Scrub;}

Or, the Workhoufe Boy's Firft Start in Life. By Mrs. Balfour. With SEVEN Engravings, 6d.

This interefting narrative of a poor London Workhoufe boy, illuftrates in a moft ftriking manner the value of "right principles," efpecially of honefty, truthfulnefs, and fobriety. It is a fuitable prefent for apprentices, and the fenior fcholars in Sunday Schools.

[Trventieth Thoufand.

\section{The Rod, and its Ufes;}

Sr: Thomas Dodd and Bill Collins. By Author of "My Flowers." With FIve Engravings, 6d.

Contents:-A Sketch of Dodd's Family Maragement and its Confequences-A Cergyman's Difficulties-Dodd feels his own Faultinefs, and fuffers for it-Firft Misfortune - Firft Comfort and Second Trouble-A Stubborn Son refufes Good Advice-Collins's Cottage: a Peep into its Politics-The Secret of Collins's Happinefs-The Hounds and the Whipper-in-Sorrow upon Sorrow-Effects of Strong Drink-Friends indeed-Comiort and Encouragement-Darknefs and Day-dawn.

London: S. W. PARTRIDGE, 9, Paternofter Row. 
THE DAIRYMAN'S DAUGHTER : an Authentic Narrative. By the Rev. Legh Richmond, M.A. With Twenty Engravings, cloth, Is. 6d.; gilt, 2s. 6d.

\section{COME HOME, MOTHER! A Story for} Mothers. By Nelsie Brook. With Ten Engravings, cloth, 1s.

\section{MAUDE'S VISIT TO SANDY BEACH.}

A Book for Girls. By the Author of "Croffes of Childhood." With Four Engravings, cloth, Is.

PROCRASTINATING MARY. A Story for Young Girls. By the Author of "Croffes of Childhood." With Two Engravings, 6d.

ROSA; or, The Two Caftles. By Mifs BRADBURn. A Tale for Girls. With EIGHT Engravings, cloth, is. [New Edition.

\section{PASSAGES IN THE HISTORY OF A} SHILLING. By Mrs. C. L. BALFour. With FIVE Engravings, cloth, Is. [New Edition.

\section{OUR DUMB COMPANIONS; or, Stories} about Dogs, Horfes, Cats, and Donkeys. By Rev. T. JACkson, M.A. With SevenTy-FIVE Engravings, cloth, 53.; gilt, 7s.6d. [Eighth Thoufand.

\section{THE LITTLE WOODMAN ஜீ HIS} DOG CAESAR. By Mrs. SHERWOOD. Parlour Iflue on toned paper, cloth, Is. 6d.; gilt, 2s. $6 \mathrm{~d}$.

[New Edition.

\section{WASTE NOT, WANT NOT. A Book} for Servants. By Mrs. SHERwood. Printed on toned paper, cloth, Is. 6d.; gilt, 2s. 6d. [Nerw Edition.

London: S. W. PARTRIDGE; '9, Paternofter Row. 


\section{Leaflets of the Law of Kindnefs.}

Edited by Elihu Burritt. In Packets, 6d.

"A Series of fimple two-leaved Tracts for Children, iffued in packets containing Sixtyfour feparate Traets in each envelope. They form one of the beft collections of infantile reading we have ever teen in fo Imall a compafs."-Dial

\section{The Bible the Book for All.}

By Jасов Post. With Twelve Engravings, $6 \mathrm{~d}$.

$\approx$ We moft cordially recommend this little book to the careful perufal of all our readers. While efpecially adapted for young people, all ages may ufe it with advantage. * * * * A better Sixpennyworth on the fame fubject is not to be found."--Morhers' Magazine.

\section{"Buy your own Cherries."}

Derfified from the Original Edition. By the Author of "Dip your Roll in your own Pot." With Fourteen Engravings, 6d.

"The author of the New Verfion deferves great credit for the facility with which, while putting the ftory into very euphonious verfe, he has contrived to retain all phrafes and expreffion which gave fpirit to Mr. Kirton's ufeful and excellent tale."-Dial.

\section{Portraits with Broad Margins,}

SUITABLE FOR FRAMING.

ABRAHAM LINCOLN, The late Prefident of the United States. Drawn by Henry Anelay, Efq. Printed on Toned Paper. Price 6d.

PRINCESS OF WALES \& INFANT PRINCE.-Copied, by Permiffion, from a Photograph by Meffrs. Bafebe and Son. Printed on Toned Paper. Price 6d.

RICHARD COBDEN.- Drawn by HENRY ANELAY, Efq., from recent Photographs. Printed on Toned Paper. Price 6d.

THE QUEEN. - A fplendid Medallion Portrait of Her Majefty, with a facfimile of her Autograph. Printed on Plate Paper. Price 6d.

PRINCE ALBERT.-A finely-executed Portrait of the late Prince. (Copied by fpecial permiffion from the Medallion, by L. C. WYon, Efq.) Printed on Toned Paper. Price 6d.

PRINCE AND PRINCESS OF WALES.-Drawn by HENRY ANELAY, Efq., and printed in tints by EDMUND Evans. Price 6d.

GARIBALDI.-A Coloured Portrait. Drawn by Henry Anelay, Efq., from a Photograph by Negretti and Zambra. Price 6d.

London: S. W. PARTRIDGE, 9, Paternolter Row. 
THREE OPPORTUNITIES; or, the Story of Henry Forrefter. With EIGHT Engravings, cloth, 2s. 6d.

\section{CROSSES OF CHILDHOOD; or, Little} Alice and Her Friends. By Mrs. WALLER. With Five Engravings, cloth, rs.

THE CHILDREN'S PARTY; or, a Day at Upland. Being Stories in Profe and Verfe. By Cousin Helen. With Six Engravings, cloth, is.

\section{SONGS

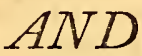 \\ HYMNS \\ FOR \\ THE}

LITTLE ONES. Compiled by UnCle John. With One Hundred AND SIXTY Engravings, cloth, 5s.; coloured plates and gilt edges, 7s. 6d.

\section{MORNING DEW-DROPS; or, the fu-} venile Abftainer. By Mrs. C. L. Balfour. With SIxTEEN Engravings, cloth, 3s. 6d.; gilt, 4s. $6 \mathrm{~d}$.

[Fifth Edition.

TOIL AND TRUST; or, Life-Story of Patty, the Workhoufe Girl. BY Mrs. Balfour. With Four Engravings, cloth, is.

[Trvelfth Thoufand,

FAMILY WALKING-STICKS; or, Profe Portraits of my Relations. By. George Mogridge (Old Humphrey), with a Preface by his Widow. With EIght Engravings, cloth, Is. 6d.

\section{THE SICK ROOM AND ITS SECRET.}

By Mrs. Thomas Geldart. With Twenty-two Engravings, cloth, is.

TOM BURTON: a Tale of the Workßop. By the Author of "The Working Man's Way in the World." With SIX Engravings, cloth, Is.

[Tenth Thoufand.

London: S. W. PARTRIDGE, 9, Paternofter Row. 


\section{"Buy your own Cherries."}

Profe Edition. By J. W. KIrTon, Efq. With Five Engravings, 6d.

"The title accords with the ftory, which abounds in the wrong-headed good fenfe and right-hearted folly which render focial fcience homilies efpecially attractive to the uneducated * * * It has already achieved a place in the ftandard literature of the claffes to whom it is efpecially addreffed, and it well deferves its popularity."-Atbencum.

[Fourtb Edition.

\section{Dick and his Donkey;}

Or, How to Pay the Rent. By the Author of "Philip Markham's Two Leffons." With Two Engravings, 6d.

"The writer tells us of a brave boy who faved his mother from lofs of houfe and probable deftitution, by earning money to pay the houfe rent. How he did this, amidft what hopes, fears, checks, dangers, and rewards, is very agreeably narrated. * * * The style is plain and unaffected. The book will be a favourite with moft young people."-Meliora.

\section{Little Jane; or, the Boat Accident.}

By Rev. Alfred Mrlls. With Seven Engravings, 6d.

Contents:-The Cottage-A Story of Dark Days-Small Sins, and how they became Great-Light in Darknefs-How do you Pray?-Violence-Where the Money Goes"Tick," not alone-Short Commons-Prayer anfwered-The Mifion of Love-Again the Tide-The Leffon not in vain.

\section{Never Give Up!}

A Chriftmas Story for Working Men and their Wives. By Nelsie Brook. With Five Engravings, 6d.

"We heartily recommend this ftory, which is well told, both to old and young, as the leffons it teaches may be useful to all."-Glafgoro Advertifer.

[Tenth Thoufand.

\section{Little Tracts for Little Folks.}

By various Authors. In Packets of Forty-eight, Illuftrated, 6d.

The Greek Teftament.-The Apple War.-A Kind-hearted Boy.-Mind the Door."No, I will not fight!"- "God blefs you, my little Fellow !"- How to raife Funds for the May Meetings. - Uncle Anthony; or, a Staff in Old Age.-The Dumb Boy's Examination. -The Reformed Shoemaker; or, "I will, if you will."-Faith.-Brave Bobby.-Kindnefs to Animals. - The Spider.—Early Rifing. - A Boy reproved by a Bird; and Eight others.

London: S. W. PARTRIDGE, 9, Paternofter Row. 
THE MOTHER'S PICTURE ALPHABET. Printed on Toned Paper. With TwEnTy-six Engravings, boards, 5s.; cloth, red edges, 7s. 6d.; gilt edges, 10s. 6d. [Seventh Thoufand.

A MOTHER'S LESSONS ON THE LORD'S PRAYER. By Mrs. BALFOUR. With Erght Engravings, illuftrated cover, 2s. $6 \mathrm{~d}$; ; cloth, $3 \mathrm{~s}$. $6 \mathrm{~d}$.; cloth extra, $5 \mathrm{~s}$.

\section{A MOTHER'S STORIES FOR HER} CHILDREN. By Mrs. CARUS Wilson. With FouR Engravings, cloth, Is.

[New Edition.

\section{A MOTHER'S LESSONS ON KIND} NESS TO ANIMALS. With ForTY-THREe Engravings, 2 vols., cloth, Is. each.

THE GOVERNESS; or, the Miffing PencilCase. By the Rev. J. T. BARr. With Twelve Engravings, cloth, Is. [Fifteenth Thoufand.

RACHEL; or, Little Faults. By Charlotte ELIzAbeth. With SEVEn Engravings, cloth, is. [Ninth Thoufand.

THE GIANTS; and How to Fight Them. By Dr. NewTon. With EIGHT Engravings, cloth, xs. [Nintb Thoufand.

THE PRINCE CONSORT: His Life and Character. By the Rev. J. H. WILson. With SIx Engravings, cloth, Is. [Twenty-firft Thoufand.

COUSIN BESSIE: a Story of routbful Earneftnefs. By Mrs. BALFour. With EIGHT Engravings, cloth, is. [Tenth Thoufand.

London: S. W. PARTRIDGE, 9, Paternofter Row. 


\section{A Peep Out of Window,}

And What Came of it. By Mrs. C. L. Balfour. With Ten Engravings, 6d.

Contents:-Mother and the Window Blind-The Two Gazers-The Contraft-A Potatoe Monument-The Dunns and their Hiftory-Their Temptation and Fall-Another Window Scene-A Ray of Light-Help from a Neighbour--An Attempt at ReformationSuccefs.

\section{THE}

\section{Paftor's Pledge of Total Abftinence.}

By the Rev. William Roaf. Price 6d.

"I have no words fufficiently ftrong to utter the intenfe earneftnefs with which I would commend this fubject to the confcientious attention of parents, teachers, and minifters of the gofpel of every denomination."-Preface.

[Tenth Thoufand.

\section{The Victim;}

Or, an Evening's Amufement at the "Vulture." With Four Engravings, 6d.

"This is a well-written and deeply interefting narrative, the leading incident of which, as the authorefs avows in her preface, is ftrictly true. The object of the ftory is to warn young girls againft the dangers and feductions of places of public amufement, fuch as cafinos and public-houfe entertainments, efpecially as they are aided by the ufe of intoxicating drinks. The narrative is a fad one, but the well-chofen words in which it is conveyed, and the purity and the earneftnefs of its ftyle, render it a very fuitable book to put in the hands of the young."-Bradford Reviezu.

\section{The Drunkard's Death.}

\section{With FIVE Engravings, 6d.}

s' We cordially recommend this fimple, touching ftory to our readers. It thows clearly what one falfe ftep may lead to, and the fuffering and forrow that too often vifit the humble homes of the fons of toil through yielding to the voice of the tempter, and indulging in habits ot intemperance."-Belfaft Nezus Letter.

\section{The Warning:}

A Narrative of Facts, addreffed to Wives and Mothers. By Mrs. C. L. Balfour. Price 6d.

This temperance narrative is commended to the nntice of working men, their wives, and their daughters. It will, it is hoped, prove a check to many in their downward courfe, through our national drinking cuftoms. 
FOHN TODD, and How he Stirred his Own Broth-Pot. By the Rev. John Allan. With Four Engravings, cloth, Is.

\section{IHOUGHTS FOR YOUNG THINKERS.}

By Aaron Hall (Old Humphrey). With 'Twenty-Nine Engravings, cloth, Is.

[Tenth Thoufand.

CLUB NIGHT: a Village Record. Edited by C. L. BaLfour. With Twelve Engravings, cloth, xs.

DOMESTIC ADDRESSES, and Scraps of Experience. By G. Mogridge (Old Humphrey). With Twenty-three Engravings, cloth, is. 6d.

\section{WANDERINGS OF A BIBLE: and My} Mother's Bible. By Mrs. BALFOUR. With EIGHT Engravings, cloth, Is. [Tenth Thoufand.

FOHN HOBBS: a Temperance Tale of Britifh India. By George Drago. With Twelve Engravings, cloth, Is. [Tenth Thoufand.

OUR MORAL WASTES, and How to Reciaim Them. By Rev. J. H. Wilson. With Four Engravings, cloth, xs. [Second Edition.

\section{SUNDAY SCHOOL ILLUSTRATIONS.}

By Ephraim Holding (Old Humphrey). With ThirtY-Nine Engravings, cloth, xs. 6d.

\section{HOMELY HINTS ON HOUSEHOLD} MANAGEMENT. By Mrs. C. L. Balfour. With Twenty-Two Engravings, cloth, xs.

$[$ Tenth Thoufand.

London: S. W. PARTRIDGE, 9, Paternofter Row. 


\section{ILLUSTRATED PENNY READINGS.}

I WHO'S YOUR FRIEND? By JohN E. GRAY. Id.

2 AUTOBIOGRAPHY OF A REFORMED THIEF. Id.

3 WHAT HAPPENED TO JOE BARKER. BYT.S. ARTHUR. Id.

4 THE LOSINGS' BANK. A Pledge For A PLEDge. Id.

5 THE PLANK WILL BEAR. A Ballad. By Rev. C. OVERTON. Id.

6 TAKE CARE OF YOUR "TIS BUTS." BY J. W. KIRTON. Id.

7 THE MARKET PINT. BY JOHN E. GRAY. $x d$.

8 THE SHABBY SURTOUT. BY R. HUIE, M.D. $\quad \mathrm{rd}$.

9 THE WONDER-WORKING BEDSTEAD. By J. W. KIRTON. Id.

ro MY ACCOUNT WITH HER MAJESTY. BY A. HallidaY Id.

II THE WOUNDED STAG. By Rev. Charles Overton. I

I3 THE TEMPERANCE LIFE-BOAT CREW. By J.W. KIRTON. Id.

I 3 POLLY PRATT'S SECRET FOR MAKING $\oint_{5}$ NOTES. Id.

14 THE LIFE BELT. BY an OLD SAILOR. $\quad x$.

I5 CRIPPLED JENNY; OR, THE VOICES OF Fl OWERS. Id.

16 THE DOINGS OF DRINK. By the Rev. S. J.STONE, B.A. (Windfor). Id.

17 HOW SAM ADAMS' PIPE BECAME A PIG. By J.W. KIRTON. Id.

18 THE SUNDAY EXCURSION TRAIN. By Rev. Dr. LEASK. Id.

Nos. I to I2, done up in cloth, 1/6; paper boards, I/; packets, I/.

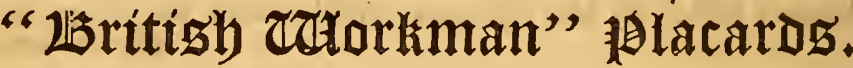

ADAPTED FOR WORKSHOPS, \&C. ILLUSTRATED BY THE FOLLOWING ARTISTS.

One Penny; Coloured, Threepence.

I JOHN ROSE AND HIS LITTLE FREEHOLD. L. Huard.

2 THE ELOQUENCE OF GRIEF. L. Huard.

3 THE WHEAT AND THE CHAFF. H. Anelay.

4 STRIKE AT THE ROOT. L. Huard.

5 "DIP YOUR ROLL IN YOUR OWN POT." H. Anelay.

6 RENT FREE. H. Anelay.

7 THE SECRET OF ENGLAND'S GREATNESS. H. Anelay.

8 JACK AND HIS HARD LUMP. H. Anelay.

9 THE DOOR IN THE HEART. H. Anelay.

Io THE LOAF LECTURE. George Cruikshank.

II HOME IN SHADOW. George Cruik?hank.

12 A THING THAT DRINKS AND SMOKES. George Cruikfhank.

I3 THE TWO PLEDGES. L. Huard.

14 KINDNESS TO ANIMALS. Sir E. Landfeer.

Nos. I to I2, done up in packet, One Shilling.

** If an order be fent with fourteen ftamps, the complete fet will be forwarded polt free.

London: S. W. PARTRIDGE, 9, Paternoster Row. 
NANCY WIMBLE, the Village Go/ph, and How the was Cured. By T. S. ARTHur. With Eight Engravings, cloch, Is. $6 \mathrm{~d}$.

THE HAUNTED HOUSE; or, Dark Paffages in the Life of Dora Langley. By Eliza S. Oldham. With Four Engravings, cloth, Is.

\section{MIND WHOM YOU MARRY; or, the} Gardener's Daughter. By the Rev. C. G. Rowe. With EIGHT Engravings, cloth, Is.

[Trventieth Thoufand.

\section{HOW FAMILIES ARE RENDERED}

HAPPY OR MISERABLE. By UnCle David. With Thirty-Four

Engravings, cloth, Is.

\section{WHAT PUT MY PIPE OUT; or, Inci-} dents in the Life of a Clergyman. Illuftrated by George Cruikshank. With FIVE Engravings, cloth, Is. 6d.

WILLY HEATH AND THE HOUSE RENT. By William Leask, D.D. With Ten Engravings, cloth, is. 6d.

\section{GOOD SERVANTS, GOOD WIVES, \&๑} HAPPY HOMES. By the Rev. T. H. WALkER. With FourteEN Engravings, cloth, Is. $6 \mathrm{~d}$.

[Tenth Thoufand.

RAINY DAYS, and How to Meet Them. By Mrs. Marshall. With Four Engravings, cloth, rs.

\section{WIDOW GREEN AND HER THREE}

NIECES. By Mrs. Ellis. With Twenty.Four Engravings, cloth, rs.

[Thirty-eights Thoufand.

London: S. W. PARTRIDGE, 9, Paternofter Row. 


\section{Nettie Leigh's Birthday.}

By A. E. R. With Five Engravings, 6d.

Contenrs:-The Pine-cone Bafket and the Sunbeams-The Drive to the Wood-The Ruins-Muff and the Hedgehog-The OwI in the Tower-The Lame Girl and the Cottage-A Difafter-The Coronation-Good Refolutions--Nettie and Minnie going Home - "Good Night, and Pleafant Dreams."

\section{Jofeph Selden, the Cripple;}

Or, an Angel in our Home. By the Author of "The Dalrymples." With FIVE Engravings, 6d.

Contents:-A Peep into John Selden's Home-Joey the Cripple-His Patience and Endurance-A Comfort to his Mother-Timely Aid-Bitter Reflections-John Selden in fearch of Employment-Settles at the Ifle of Wight-Joey a Cripple for Life-Is carried to the Beach-A Lady Vifitor-Promife of a Bible-Bookmarkers-The Hapry Transformation-Joey does what he can for Miffions-Is made a Bleffing-He Sickens and Dies.

\section{Friends of the Friendlefs;}

Or, a Few Chapters from Prifon Life. By Mrs. Balfour. With Nine Engravings, 6d.

"Short fketches of philanthropifts, chiefly in humble life, well adapted to incite the poffeffors of a fingle talent to turn it to good account, by fhowing what the poor have been able to do for the poor." - Englifhwoman's fournal.

\section{Pity the Little Ones!}

Or, Little Ellen the Gleaner. By the Author of "Haunted Houfe." With Two Engravings, 6d.

"We thould think it would be almoft impoffible for any one to read this graphic sketch of the drunkard's home and child, without being moved with pity and fympathy for the little ones. We would earneftly recommend parents and Sabbath-fchool teachers to purchafe and carefully read this interefting narrative."-Maidfone Temperance Vifitor.

\section{How Sam Adams' Pipe became a Pig.}

By J. W. Kirton, Author of "Buy your own Cherries." With Five Engravings by Cruikfhank.

Contents :- How Sam loved his Pipe, and how he went to fee the Wild Beafts-How Mr. Wombwell objected to Smoking, becaufe it taught the Monkeys Bad Habits-Sam burns his Idol, and his Clothes from off his Back-Dr. Prout's opinion of the Weed-Little Pigs with Straws in their mouths-Charley puts a very awkward queftion-Sam becomes thoughtful, efpecially when his wife calls him a "Walking Chimey-pot"-Self-conqueft and Victory. 


\section{BIBLE PRINTS: a Series of Twenty-four}

beautifully Tinted Engravings, illuftrative of the Old and New Teltaments. By Profeffor SchNorR. With Explanatory Letterprefs by the Rev. JоHN Rose, B.D., and the Rev. J. W. BURGon, M.A. With TWENTY-Four Engravings, paper covers, $4 \mathrm{~s}$.

A VOICE FROM THE VINTAGE; or, the Force of Example. By Mrs. Ellis. Crown 8vo,, cloth, is.

[Fourth Edition.

\section{IRUTH FR AE'MANGTHE HEATHER;} or, Is the Bible True? By a Working Man. With Six Engravings, cloth, is.

[Fourth Thoufand.

\section{HAVE WE ANY WORD OF GOD?}

The Queftion of the Day. By the Author of "Is the Bible True ?" With SEVEN Engravings, cloth, rs.

\section{THE TWO CHRISTMAS DAYS. THE} CHRISTMAS BOX. By Mrs. Balfour. With Five Engravings, cloth, Is.

\section{THE CHRISTIAN MONITOR; or, Selec-} tions from Pious Authors. With Fifty Engravings, cloth, 2s. 6d.; cloth, gilt edges, 3s. 6d.

\section{ILLUSTRATED HANDBILLS, for} General Diftribution. With Eightr-three Engravings, 8vo., cloth, and in packets, Is. each. Each Handbill may alfo be had feparate, in SIXPENNY Packets, afforted or otherwife.

TRACTS FOR THE SUPPRESSION OF INTEMPERANCE. In afforted packets. Many Engravings, rs.

London: S. W. PARTRIDGE, 9, Paternofter Row. 


\section{THREEPENNY ILLUSTRATED BOOKS.}

INCIDENTS IN THE LIFE OF A NATIVE OF BIRMINGHAM; or, the Cottage of Content. Sixth Thoufand.

A MESSAGE FROM WHITECHAPEL; or, Scenes in a London Hospital. By Augurta Johnftone. Third Thoufand. 3d. YOUNG SUSAN'S FIRST PLACE; or, a Young Servant's Difficulties.

UNCLE DAVID'S VISIT TO A NEWMARRIED WIFE, and the Good

Counfels he gave her. Third Thoufand. $3 d$. UNCLE DAVID'S ADVICE TO YOUNG MEN AND YOUNG WOMEN ON MARRIAGE. Third Thoufand.

ANNIE BAKER; or, the Little Pilgrim. By Mifs M. Murchifon. Fifth Thoufand.

CHARLEY'S DISAPPOINTMENT; or Making the Beft of it. By Mrs. Carey Brock. New Edition.

MORE WAYS THAN ONE; or, the Little Miffionary. By Mrs. Carey Brock. New Edition. $3 d$.
THE WANDERERS RECLAIMED; or, Truth Stronger than Fiction. Fifth Thoufand.

3d. SEED-TIME AND HARVEST; or, the Sailor-Boy's Return.

AN ADDRESS TO YOUNG SERVANTS, efpecially to thofe juft entering Service. Third Thoufand.

WHAT SMALL HANDS MAY DO; or, Filial Affection. New Edition. $3 d$. FRANK'S SUNDAY COAT; or, the Sabbath kept Holy.

JOHN JARVIS, the Reformed Hatter. $3 d$. THE TWO HOMES AND THE Secret. By Mrs. Balfour. 3d. THE CABMAN'S HOLIDAY. A Tale. By Mifs Sinclair.

HINTS FOR SMOKERS; on the Ufe and Abufe of Tobacco.

3d. THE STRIKE. A Little Comedy. "Live and let Live."

ROSA MAY'S CHRISTMAS DREAM, 3d. and What came of it. By Nelfie Brook. $3 d$.

\section{TWOPENNY ILLUSTRATED TRACTS.}

WILLIAM AND MARY; or, the Fatal - QLD OSCAR, THE FAITHFUL DOG.

Blow. By Mrs. Ellis.

2d. By H. G. Reid, Esq.

HISTORY AND MYSTERY OF A GLASS OF ALE. By the Author of "Buy your own Cherries."

\section{PENNY ILLUSTRATED TRACTS.}

CONSTANCE E. KENT; or, Sin a Sure Detective.

HOW TO GROW A PLANT, and Win a Prize. TOTAL ABSTINENCE FROM ALCOHOLIC or INTOXICATING DRINK, Safe, Legitimate, and Expedient. HOPE FOR NUMBER TWO, HELP FROM NUMBER ONE.

THE ORPHAN BOY; or, How Little John was Reclaimed.

SUNDAY ON "THE LINE;" or, Plain Fakts for Working Men.

PROVIDENCE ROW ; or, the Succefsful Collier. By the Rev. T. H. Walker. Id. THE CAROL SINGERS; or, Giving better than Receiving.
AUNT MARY'S PRESERVING KETTLE. By T. S. Arthur.

SLAVERY IN ENGLAND. A Vifion of the Night.

A LITTLE VOICE. A Sudden Snare, By Mrs. Balfour.

LOW WAGES; or, Thrift and Good Management.

WHAT ARE BANDS OF HOPE, AND HOW TO FORM THEM.

IS HALF BETTER THAN THE WHOLE? A Converfation about Sunday Trading.

LIVE AND LET LIVE: a Plea for Publicans and Servants. $8 \mathrm{pp}, 2 / 6$ per hundred. 



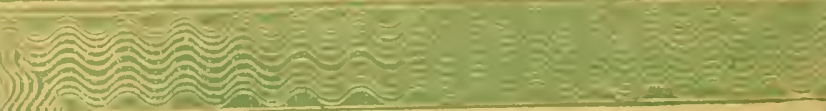

i)) $))(1))$

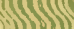

$((<(<(<(<)$

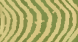

(c)

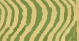

(4)

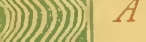

$\sqrt{1})$

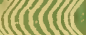

(i)))) )) $)$

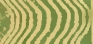

))) )) $)$

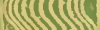

8))) )) )

)( ( ( (

(5))))))

: ( $((c(c(()$

(i)))) ))

(1)) $)$

)(c(c( ((C)

)(《( ( (

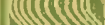

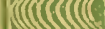

j))) ))

)$(((c)$

A MOTIER'S STORIES FOR HER CHILDREN. By Mrs. Carus Wilson, With Four Engravings, cloth, Is.

[Nern Edition.

A MOTHER'S. LESSONS ON KINDNESS TO ANIMALS. With FORTY-ThREE Engravings, 2 vols., cloth, Is. each.

THE GOVERNESS; or, the Mifing PencilCafe. By the Rev. J.T. BARr. With Twelve Engravings, cloth, Is.

[Fifteinth Thoufand.

RACHEL; 0r, Little Faults. By Charlotte Elizabeth. With Seven Engravings, cloth, is.

[Ninth Thoufand.

THE GIANTS; and How to Fight Them. By Dr. Newron. With Erght Engravings, cloth, Is.

[Nintb Tboufand.

THE PRINCE CONSORT: His Life and Character. By the Rev. J. H. Wirson. With Six En. gravings, cloth, Is.

[Twenty-firft Thoufand.

\section{COUSIN BESSIE: a Story of Youthful Earnestnels. By Mrs. BALFour. With Eight Engravings, cloth, Is \\ [Tentb Thoufand.}

CROSSES OF CHILDHOOD; or, Little Alice Harriet and her Friends. By MIrs. WAlLer. With Five Engravings, cloth, is.

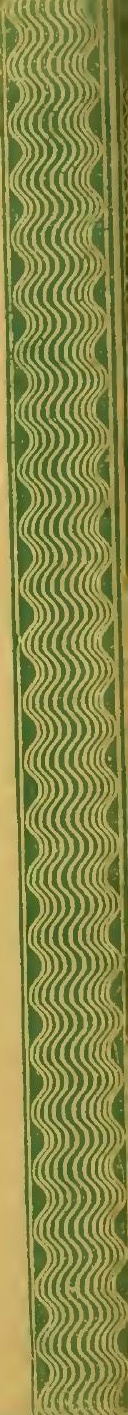

London: S. W PARTRIIGE, 9 , Paternofter Row. 


\section{THREE OPPORTUNITIES; or, the \\ Story of Henry Forrefter. With Eigrr Engravings, cloth, 2s. $6 \mathrm{~d}$.}

THE CHILDREN'S PARTY; or, a Day at Upland. Being Stories in Profe and Verfe. By Cousin Erren. With Six Engravings, cloth, Is.

SONGS AND HYMNS FOR THE LITTLE ONES. Compiled by UNCLE John. With ONs Hundred ANd Sixty Engravings, cloth, 5s.; coloured plates and gilt edges, 7 s. $6 \mathrm{~d}$.

MORNING.DE'T ${ }^{\top}-D R O P S$; or, the Juvenile Abitainer. By +.rs. C. L. Barfour. With Sixteren Engravings, cloth, 3s. 6d, ; gilt, 4s. 6d.

[Fifth Edition.

TOIL AND TRUST; or, Life-Story of Patty, the Workhoufe Girl. By Mrs. Barfour. With Four Engravings, cloth, $x$ s.
[Truelfth Tboufand.

FAMILY WALKING-STICKS ; or, Profe Portraits of my Relations. By George MIogridge (Old Humphrey), with a Preface by his Widow. With EIGHT Engravings, cloth, Is. 6d.

THE SICK ROOM \&ITS SECRET. By Mrs. Thomas Geldart. With Twenty-Two Engravings, cloth, Is.

TOM BURTON: a Tale of the WorkShop. By the Author of "The Working Man's Way in the World." With Six Engravings, cloth, Is.

[Tentb Tboufand.

Lonton: S. W. PARTRIDGE, 9, Paternofter Row.

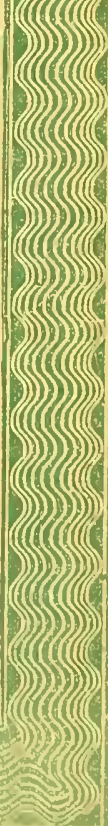




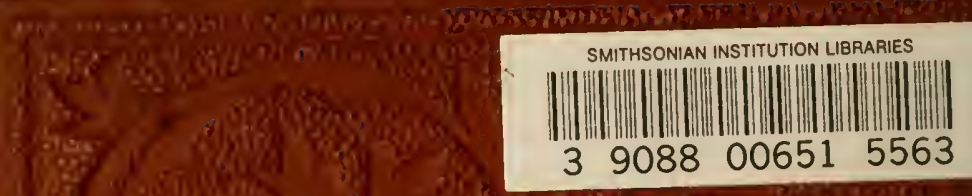

